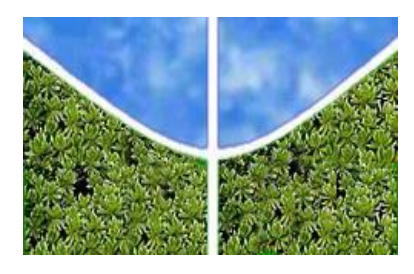

UNIVERSIDADE DE BRASÍLIA

INSTITUTO DE CIÊNCIAS BIOLÓGICAS

DEPARTAMENTO DE BOTÂNICA

PROGRAMA DE PÓS-GRADUAÇÃO EM BOTÂNICA

AVALIAÇÃo DE METODOLOGIAS MOLECULARES E CITOGENÉTICAS PARA DETECTAR NÍVEIS DE DETERIORAÇÃO EM SEMENTES DE SOJA (Glycine max

(L.) MERR.) E CEVADA (Hordeum vulgare L.)

RENATA MIRANDA LOPES

BRASÍLIA

DISTRITO FEDERAL

NOVEMBRO DE 2016 
UNIVERSIDADE DE BRASÍLIA

INSTITUTO DE CIÊNCIAS BIOLÓGICAS

DEPARTAMENTO DE BOTÂNICA

PROGRAMA DE PÓS-GRADUAÇÃO EM BOTÂNICA

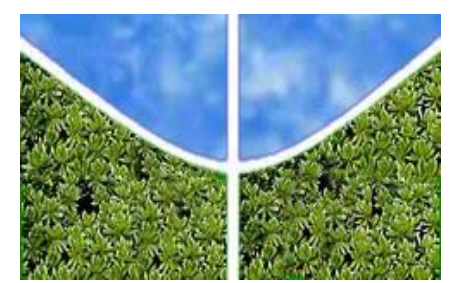

AVALIAÇÃO DE METODOLOGIAS MOLECULARES E CITOGENÉTICAS PARA DETECTAR NÍVEIS DE DETERIORAÇÃO EM SEMENTES DE SOJA (Glycine max

(L.) MERR.) E CEVADA (Hordeum vulgare L.)

Renata Miranda Lopes

Orientador: Dr. Marcos Aparecido Gimenes

Co-orientador: Dr. Juliano Gomes Pádua

Brasília

Distrito Federal

Novembro de 2016 


\author{
UNIVERSIDADE DE BRASÍLIA \\ INSTITUTO DE CIÊNCIAS BIOLÓGICAS \\ DEPARTAMENTO DE BOTÂNICA \\ PROGRAMA DE PÓS-GRADUAÇÃO EM BOTÂNICA
}

\title{
AVALIAÇÃO DE METODOLOGIAS MOLECULARES E CITOGENÉTICAS PARA DETECTAR NÍVEIS DE DETERIORAÇÃO EM SEMENTES DE SOJA (Glycine max \\ (L.) MERR.) E CEVADA (Hordeum vulgare L.)
}

\author{
Renata Miranda Lopes
}

Tese apresentada ao Programa de Pós - Graduação em Botânica do Departamento de Botânica, Instituto de Ciências Biológicas da Universidade de Brasília como parte dos requisitos necessários para a obtenção do título de Doutor em Botânica.

BRASÍLIA

DISTRITO FEDERAL

NOVEMBRO 2016 


\section{DEDICO...}

A Deus, que me ampara e me dar forças

para prosseguir.
“...Ele verá o fruto do penoso trabalho de sua alma, e ficará satisfeito” (Isaías 53:11)

“...Ebenézer...Até aqui nos ajudou o Senhor" (1 Samuel 7:12).

OFEREÇO...

À minha Família, em especial a meus pais Mirandolina Miranda e Odilon Lopes. 


\section{AGRADECIMENTOS}

A Deus, que nunca me desamparou estando comigo nos momentos alegres e nos mais difíceis;

Aos meus pais Odilon e Miranda, aos meus irmãos César e Paulinho, minhas irmãs Fátima, Leda e Carina; minha família querida, sem a qual não teria chegado até aqui;

Às minhas sobrinhas e sobrinhos, em especial ao meu amado e lindo Ryan pela amizade, pela parceria na cozinha, nas caminhadas, nas brincadeiras e por todo amor e carinho que sempre teve por essa tia coruja;

À minha tia Tezinha pelo carinho e amizade;

Ao meu orientador Marcos Gimenes, por me acolher no doutorado, pelos ensinamentos, pela paciência e amizade;

Ao meu co-orientador Juliano Pádua, por me receber no laboratório de sementes, pela a orientação nas análises fisiológicas e preparo de amostras;

À Embrapa Recursos Genéticos e Biotecnologia, onde desenvolvi toda a tese;

À Dra. Solange Roveri Jóse, pelo auxílio e ensinamentos nas análises fisiológicas, preparo de amostras e teste de condutividade elétrica;

À minha querida amiga Paula Vasconcelos pela amizade e auxílio na técnica de qPCR;

À Dra. Ana Brasileiro pela orientação no qPCR, atenção e paciência;

A toda equipe do LPP3, em especial ao Mario pelo auxílio e ensinamentos no qPCR;

A todos do Laboratório de Genética Animal, em especial ao Gleisson por todo o auxílio;

Ao Laboratório de Genética Vegetal, em especial à Lorena e Zilneide pela atenção e por todo o auxílio prestado;

Ao Prof. Cesar Grisolia, ao seu doutorando Alisson Dantas e a toda equipe do Laboratório de Genotoxicologia da UnB pelo auxílio na otimização das análises de lâminas;

Aos amigos do Laboratório de Química de Produtos Naturais Ismael Silva, Rosa de Belém e Tânia Agostini pelo auxílio, presteza e amizade;

Ao Prof. Lúcio Alencar do Dep. de Botânica - UnB pela atenção, ensinamentos, dicas e dúvidas sanadas;

À querida Antonieta Salomão pelas boas conversas e amizade;

A toda equipe do Prédio da Conservação de Germoplasma, em especial Ana Paula, Bila, Cícero, Dani, Dona Ana, Izulmé, Raquel e Rosa pela atenção e presteza;

Aos amigos Daniele Wondracek, Dilva Brandão e Wesley Rocha pela amizade e companheirismo;

E a todos que direta ou indiretamente contribuíram para a realização desse trabalho. 


\section{SUMÁRIO}

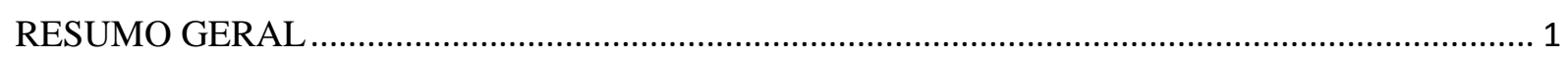

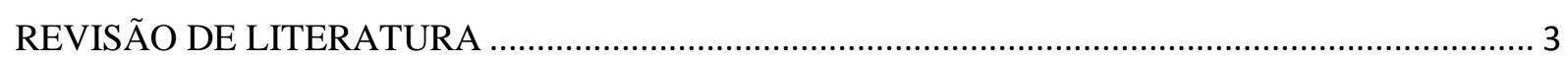

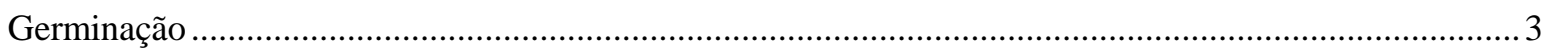

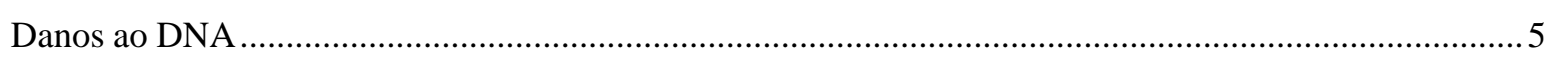

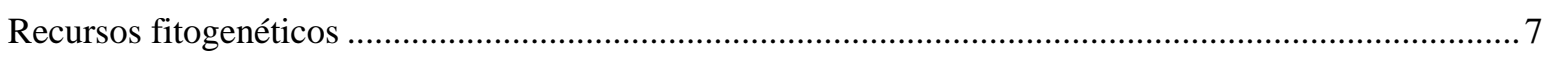

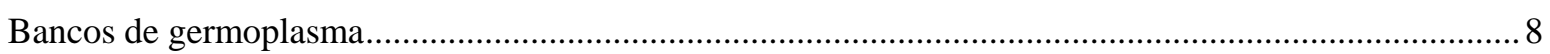

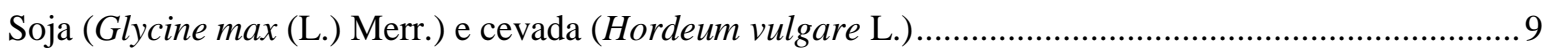

CAPÍTULO 1. OBTENÇÃO E CARACTERIZAÇÃO FISIOLÓGICA DE LOTES DE SEMENTES DE SOJA E CEVADA ENVELHECIDAS ARTIFICIALMENTE.................................................... 19

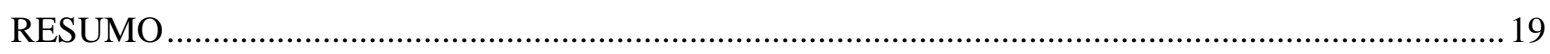

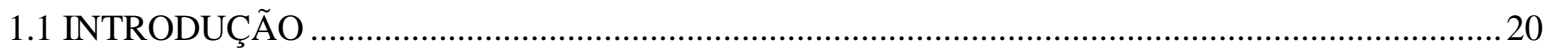

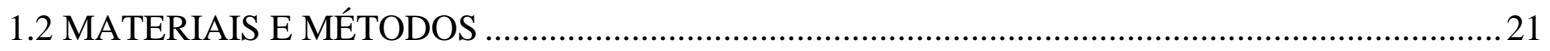

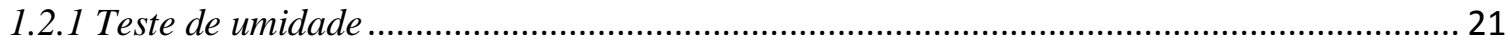

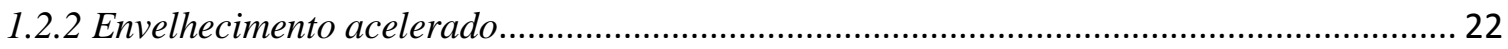

1.2.3 Teste de germinação e índice de velocidade de germinação .............................................. 23

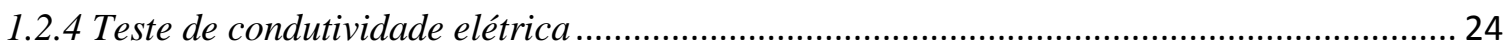

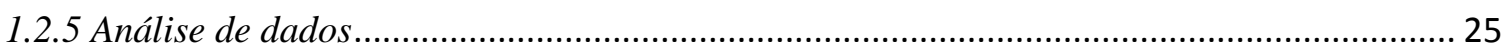

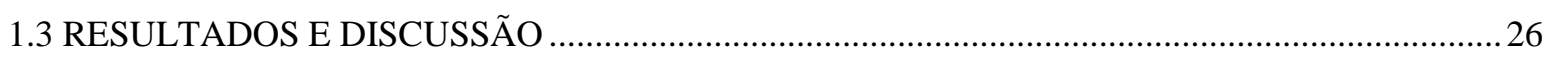

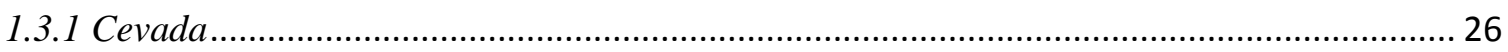

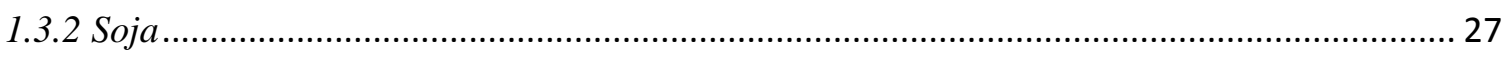

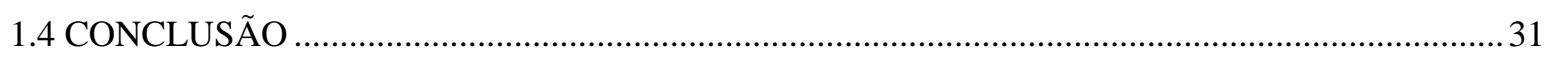

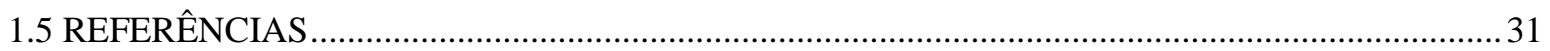

CAPÍTULO 2. QUANTIFICAÇÃO DE ÁCIDOS NUCLEICOS ORIUNDOS DE EMBRIÕES DE SOJA EM DIFERENTES NÍVEIS DE DETERIORAÇÃO ……................................................... 34

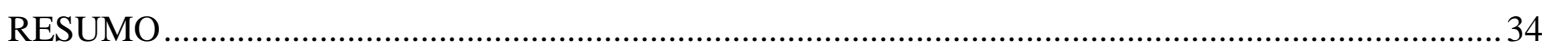

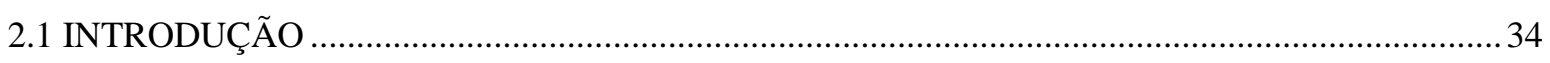

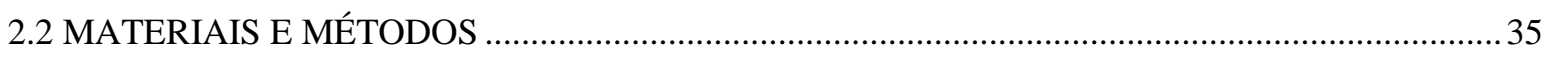

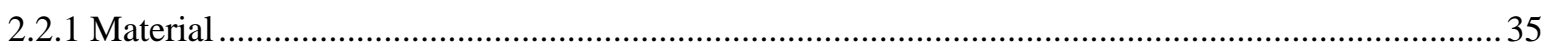

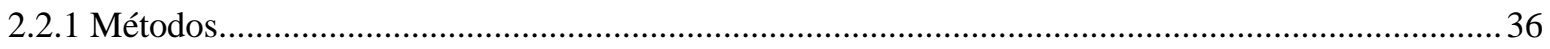

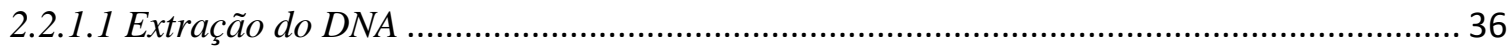

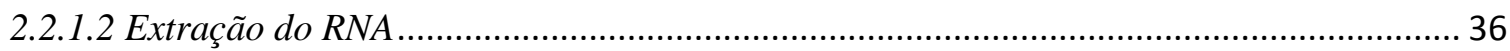

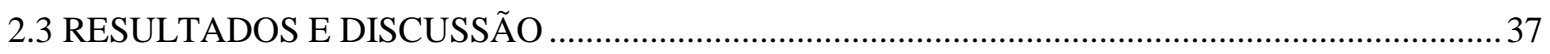

2.3.1 Obtenção de controle positivo de degradação de DNA ....................................................... 37

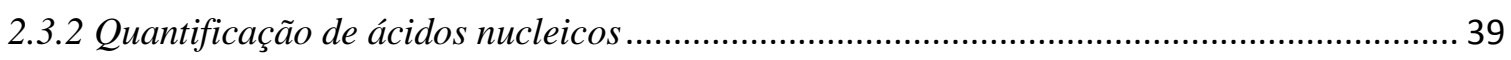

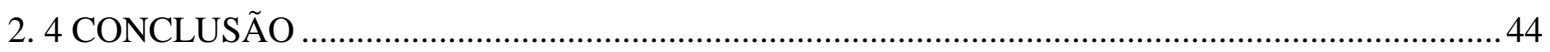


2. 5 REFERÊNCIAS

CAPÍTULO 3 - AVALIAÇÃO DA INTEGRIDADE DE ÁCIDOS NUCLEICOS EM SEMENTES DE SOJA E CEVADA ENVELHECIDAS ARTIFICIALMENTE 46

RESUMO 46

3.1 INTRODUÇÃO 46

3.2 MATERIAL E MÉTODOS 48

3.2.1 Material 48

3.2.2 Métodos 48

3.2.2.1 Experimento de embebição. 48

3.2.2.2 Extração de ácidos nucleicos 48

3.2.2.3 Análise de RAPD 50

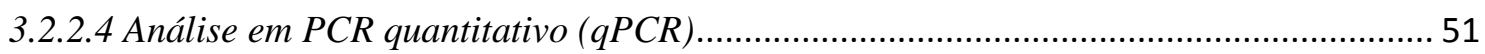

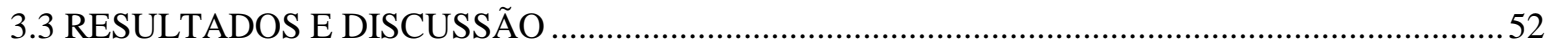

3.3.1 Avaliação da degradação e reparo do DNA em gel de agarose e eletroforese.................. 52

3.3.2 Avaliação da integridade do RNA por gel de agarose e eletroforese ............................... 58

3.3.3 Avaliação do sistema de reparo do DNA e introdução de variabilidade utilizando-se marcadores RAPD. 62

3.3.4 Avaliação da degradação do DNA por PCR quantitativo (qPCR).................................... 70

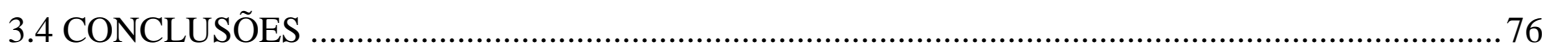

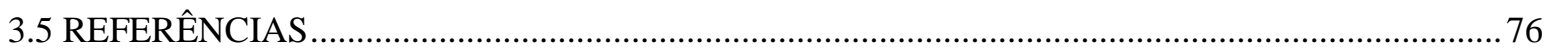

CAPÍTULO 4. ANORMALIDADES CROMOSSÔMICAS E MITÓTICAS EM AMOSTRAS SOJA

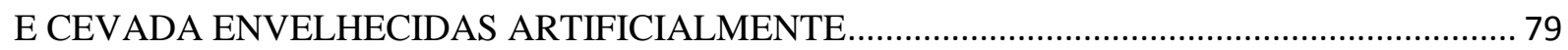

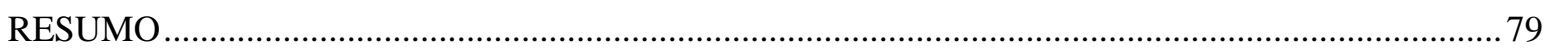

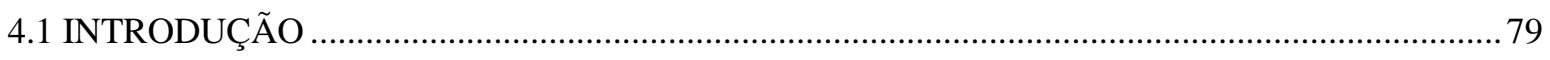

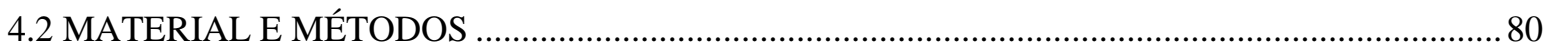

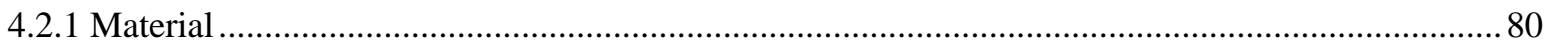

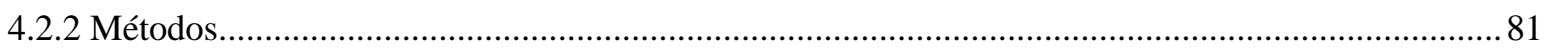

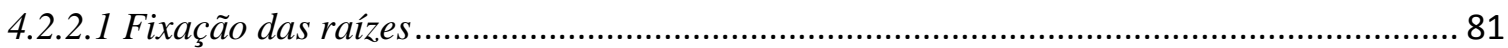

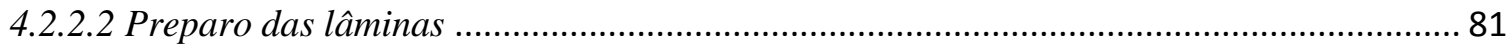

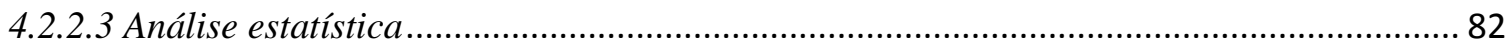

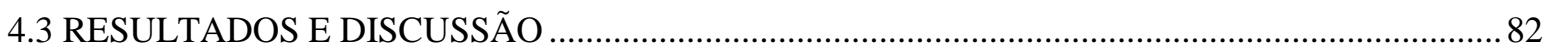

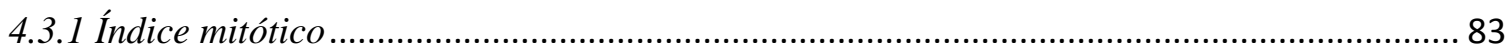

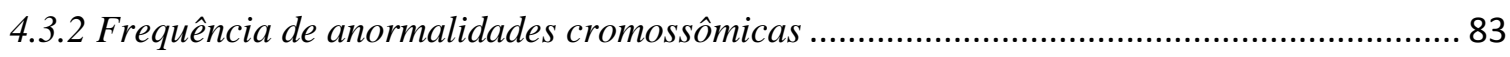

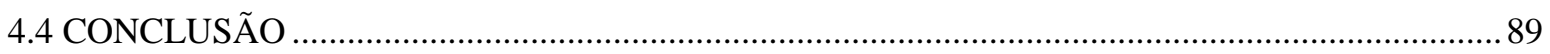

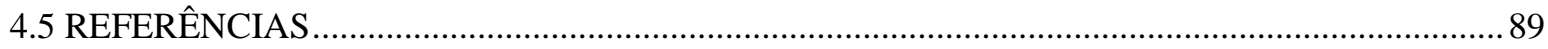

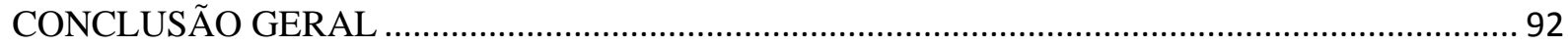




\section{LISTA DE FIGURAS}

Figura 1. Curso de tempo dos eventos físicos e metabólicos que ocorrem durante a

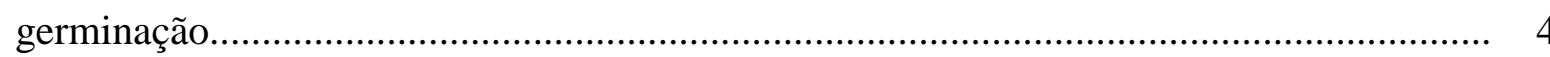

Figura 2. Principais vias que determinam o vigor das sementes.................................. 5

Figura 3. Reparo de dano à fita simples do DNA por inserção de nucleotídeos................ 6

Figura 4. Mecanismos de reparo ao dano à fita dupla do DNA …................................. 7

Figura 1.1. Sementes de soja preparadas para o envelhecimento acelerado...................... 22

Figura 1. 2. Sementes de soja dispostas em papel germitest para o teste de germinação....

Figura 1.3. Teor de água nas sementes de soja BRS 7980 no decorrer do envelhecimento acelerado

Figura 2.1 Amostras de DNA que passaram por diferentes métodos para indução de fragmentação.

Figura 2.2. Quantificação dos DNAs oriundos de processo de degradação a $95^{\circ} \mathrm{C}$ em cinco diferentes tempos, calculado por diferentes metodologias de quantificação.

Figura 2.3 Variação na concentração do DNA entre as diferentes metodologias de quantificação.

Figura 2.4. Quantificações por comparação com DNA padrão com concentração conhecida.

Figura 3.1. Análise do DNA das sementes de soja cv BRS Flora envelhecidas artificialmente.

Figura 3.2. Análise do DNA dos embriões da soja cv BRS 7980.

Figura 3.3. Análise do DNA em gel das sementes de cevada. 
Figura 3.4. Análise semi-quantitativa da deterioração do DNA das sementes de cevada..

Figura 3.5. Análise do RNA das sementes de soja.....

Figura 3.6. Variação da concentração do RNA durante o envelhecimento acelerado de sementes de soja.

Figura 3.7. Padronização da metodologia de RAPD

Figura 3.8. Análise de agrupamento para as amostras de soja. 65

Figura 3.9. Variação no padrão de bandas ao longo do envelhecimento e embebição ...... 67

Figura 3.10. Análise de cluster para as amostras de cevada.

Figura 3.11. Dispersão dos CTs entre as amostras avaliadas para cada primer com fragmentos de diferentes tamanhos

Figura 3.12. Interação entre o tratamento de deterioração do DNA e o comprimento do par de primer sobre os CTs.

Figura 3.13. Relação entre a taxa de germinação das sementes e os valores de CT para os diferentes lotes de sementes e diferentes comprimentos de fragmentos avaliados.

Figura 3.14. Análise de agrupamento das amostras estudadas com base nos CTs obtidos para todos os comprimentos de fragmentos avaliados. 75

Figura 4.1. Raízes de soja e cevada no momento da coleta.

Figura 4.2. Células normais e anormais de raízes de cevada após tratamento de envelhecimento artificial

Figura 4.3. Células meristemáticas regulares e anormais de soja após envelhecimento acelerado 


\section{LISTA DE TABELAS}

Tabela 1.1. Valores médios das análises fisiológicas da cevada seguido do desvio padrão

Tabela 1.2. Valores médios das análises fisiológicas da soja cv BRS Flora, seguido do desvio padrão

Tabela 1.3. Valores médios das análises fisiológicas da Soja cv BRS 7980, seguido do desvio padrão

Tabela 1.4. Comparação da germinação e o índice de velocidade de germinação da Soja cv BRS 7980, logo após o envelhecimento e após a secagem das amostras para o armazenamento

Tabela 2.1 Teste comparativo da quantificação de DNA de diferentes organismos por diferentes metodologias $(\mathrm{em} \mathrm{ng} / \mu \mathrm{L})$.

Tabela 2.2. Teste comparativo da quantificação de RNA por diferentes metodologias em grupos de amostras com diferentes tempos de envelhecimento.

Tabela 3.1. Concentrações de RNA nas sementes inteiras de soja (duas sementes) e cevada (cinco sementes) obtidas de diferentes métodos de extração.

Tabela 3.2. Variação no número de bandas para as amostras de soja após envelhecimento

Tabela 3.3. Análise fisiológica das sementes de cevada utilizadas na análise de RAPD

Tabela 3.4. Variação média, seguida de desvio padrão nos CTs das amostras de DNA aquecido a $95^{\circ} \mathrm{C}$ por quatro diferentes tempos para cada comprimento de fragmentos

Tabela 4.1. Valores médios seguidos do desvio padrão da análise fisiológica e citogenética e de soja e cevada após envelhecimento acelerado. 


\section{LISTA DE ABREVIATURAS E SÍMBOLOS}

BGs: bancos de germoplasma

BOD: Biochemical oxygen demand (demanda bioquímica por oxigênio)

BSA: Bovine serum albumin

CE: condutividade elétrica

CT: cycle threshold

CTAB: brometo cetiltrimetilamônio

cv: cultivar

DSB: double-strand break (dano à dupla fita)

EDTA: ácido etilenodiamino tetra-acético

$\mathrm{HCl}$ : ácido clorídrico

IVG: índice de velocidade de germinação

LiCl: cloreto de lítio

MN: micronúcleo

$\mathrm{NaCl}$ : cloreto de sódio

NBUD: nuclear bud (broto nuclear)

PVP: polivinilpirrolidona

qPCR: reação em cadeia da polimerase quantitativa

RAPD: random amplification of polymorphic DNA

RFs: recursos fitogenéticos

S: siemens

SSB: single-strand break (dano à fita simples)

TA: teor de água

TAE: tris-Acetato-EDTA

TBE: tris/Borato/EDTA

TE: tris-EDTA

Tris: trisaminometano

UR: umidade relativa

USDA: United States Department of Agriculture

$\mathrm{V}$ : volt 


\section{RESUMO GERAL}

O teste de germinação tem sido utilizado rotineiramente na verificação do poder germinativo de sementes em bancos de germoplasma. Entretanto, essa metodologia não é muito eficaz em detectar diferentes estágios de deterioração, muitas vezes indicando apenas a morte da semente. Antes da perda visível da viabilidade das sementes em conservação ocorrem diferentes processos, entre eles estão aqueles que levam a danos às estruturas dos ácidos nucleicos. O objetivo desse trabalho foi avaliar metodologias moleculares e citogenéticas como ferramentas auxiliares ao teste de germinação na avaliação da integridade de sementes. Foram utilizadas sementes de soja e cevada como modelo. Utilizando o envelhecimento acelerado, foram obtidos lotes de sementes em diferentes estágios de deterioração, os quais foram caracterizados utilizando-se testes fisiológicos (teste de germinação, índice de velocidade de germinação e teste de condutividade elétrica). A integridade do DNA e seu reparo foram avaliados em gel de agarose $1 \%$ corado com brometo de etídio, RAPD e qPCR. A integridade do RNA extraído das sementes foi estimada avaliando-se a intensidades das bandas 18 e $28 \mathrm{~s}$ em gel de agarose. Foram comparados também o índice mitótico (IM) e a frequência de anormalidades cromossômicas (ACs) entre diferentes lotes de sementes obtidos por envelhecimento acelerado. No geral, os testes fisiológicos diferenciaram os lotes de sementes em diferentes estágios de deterioração. A avaliação das integridades do DNA e RNA em gel de agarose teve pouca repetibilidade e não permitiram a distinção entre os lotes ou necessitaram de uma grande quantidade de material (1-3 $\mu \mathrm{g})$. Os resultados do RAPD mostraram diferenças na integridade e na capacidade de reparo do DNA entre os diferentes lotes de sementes. Já o qPCR permitiu a diferenciação dos lotes das amostras e necessitou de pouco DNA (6 ng por repetição). O IM e as ACs, diferenciaram os lotes de sementes com diferentes estágios de deterioração. Entretanto o IM os diferenciou melhor, pois formou mais grupos diferentes entre os tempos de envelhecimento avaliados do que as ACs. Assim, as técnicas de RAPD, qPCR, análise do IM e das ACs podem ser ferramentas auxiliares na avaliação da viabilidade de sementes, pois foram capazes de distinguir diferentes estágios de deterioração das sementes, além de necessitarem de poucas sementes e a citogenética e o RAPD serem metodologias baratas.

Palavras - chave: conservação, dano ao DNA, envelhecimento, integridade do RNA, sistema de reparo do DNA. 


\section{GENERAL ABSTRACT}

The germination test is the most commonly used technique for monitoring seed quality in gene banks. However, this methodology does not allow the detection of different stages of deterioration and sometimes indicates merely the final step, i.e., seed death. Different processes, such as damage to nucleic acids, occur before visible loss of the seed viability. The objective of this study was to evaluate molecular and cytogenetic methods as auxiliary tools to the germination test, to evaluate seed integrity. Soybean and barley seeds were used as models. Artificial aging was used to obtain seeds representing many different deterioration stages. These seed lots were characterized using physiological tests (germination test, germination speed index test, and electrical conductivity test). The DNA integrity and repair system were evaluated using agarose gel, random amplified polymorphic DNA (RAPD), and quantitative PCR (qPCR). The RNA integrity was estimated based on the intensity of ribosomal RNA bands $18 \mathrm{~s}$ and 28s as detected on agarose gel stained with ethidium bromide. The mitotic index (MI) and frequency of chromosomal abnormalities (CAs) were evaluated in different seed lots of barley and soybean. In general, the results of the physiological tests differed among seed lots that had different deterioration stages. Generally, the evaluation of DNA and ribosomal RNA on agarose gel does not allow the characterization of the different sample lots, did not show reproducibility among biological replicates, and large quantities of samples were required (1-3 $\mu \mathrm{g})$. RAPD allowed the evaluation of integrity and DNA repair system capacity. The qPCR identified sample lots requiring a small amount of DNA (6 ng). Seed lots could be differentiated by MI and CAs. However, differentiation by MI showed an improved performance because it formed a larger number of different groups between the evaluated aging times than the CAs. Therefore, the RAPD, qPCR, MI, and CAs analyses can be auxiliary tools in the evaluation of seed viability because they were able to distinguish between different stages of seed deterioration. Additionally, these methods require few seeds and cytogenetics and RAPD are inexpensive methods.

Key-words: aging, conservation, DNA damage, DNA repair system, RNA integrity. 


\section{REVISÃO DE LITERATURA}

\section{Germinação}

A germinação é um dos mais importantes processos do ciclo de vida da planta (Tan et $a l .$, 2013) e devido à sua alta vulnerabilidade à doenças, é considerado o estágio mais crítico da vida da planta (Rajjou et al., 2012). Trata-se de um processo complexo, no qual a semente deve recuperar-se rapidamente do estado de desidratação e completar eventos celulares essenciais para que o embrião possa emergir e desenvolver a plântula (Nonogaki et al., 2010). Por definição, a germinação se inicia com a embebição e termina com a protrusão radicular (Bewley, 1997).

Como descrito na Figura 1, a embebição das sementes se divide em três fases clássicas: fase I - que se caracteriza pela rápida absorção de água; fase II - fase platô, que se caracteriza por um período de baixa absorção de água; e Fase III - na qual ocorre o alongamento do embrião, rompimento das camadas que o cobrem e também o aumento no consumo de água (Bewley, 1997; Nonogaki et al., 2010).

Para Rajjou et al. (2012), o principal componente para o sucesso da germinação é a integridade dos mRNAs durante a maturação do embrião na planta mãe. A síntese de proteínas e a atividade respiratória envolvem componentes armazenados no interior da semente seca madura, a transcrição e a tradução começam na primeira fase da embebição (Nonogaki et al., 2010).

Com a secagem e a reidratação da semente seca, podem ocorrer danos às membranas no início da embebição, como também às organelas como as mitocôndrias e até mesmo ao DNA e esses danos devem ser reparados durante a germinação (Nonogaki et al., 2010). O reparo aos danos no DNA é um dos primeiros eventos que ocorrem durante a reidratação, por exemplo, em embriões de beterraba foi observado que o reparo do DNA ocorre após duas horas do período de embebição (Redfearn et al., 1997).

Os DNAs de sementes estão sujeitos a lesões não apenas durante a dessecação, mas também durante o armazenamento, devido ao envelhecimento (Figura 2) (Rajjou et al., 2012). O DNA pode ser danificado por processos químicos, como por exemplo, pela ação das enzimas reativas de oxigênio, que podem reagir com as bases nitrogenadas e levar a mutações substitutivas (Wallace et al., 2004). O dano ao DNA tem papel importante nos processos de envelhecimento de sementes e o seu reparo tem papel crucial durante a embebição, preservando o vigor da semente, como também na integridade do genoma (Borh et al., 2002; 
Balestrazzi et al., 2011; Balestrazzi et al., 2015). Em mamíferos, há evidências que o envelhecimento esteja relacionado à queda no sistema de reparo do DNA e alguns estudos sugerem que em plantas isso também ocorra (Tuteja et al., 2001; Golubov et al., 2010). Em sementes, sabe-se que o alto teor de água durante o armazenamento está relacionado com danos ao DNA por envelhecimento (El-Maarouf-Bouteau et al., 2011), sendo necessária a secagem das sementes antes do armazenamento.

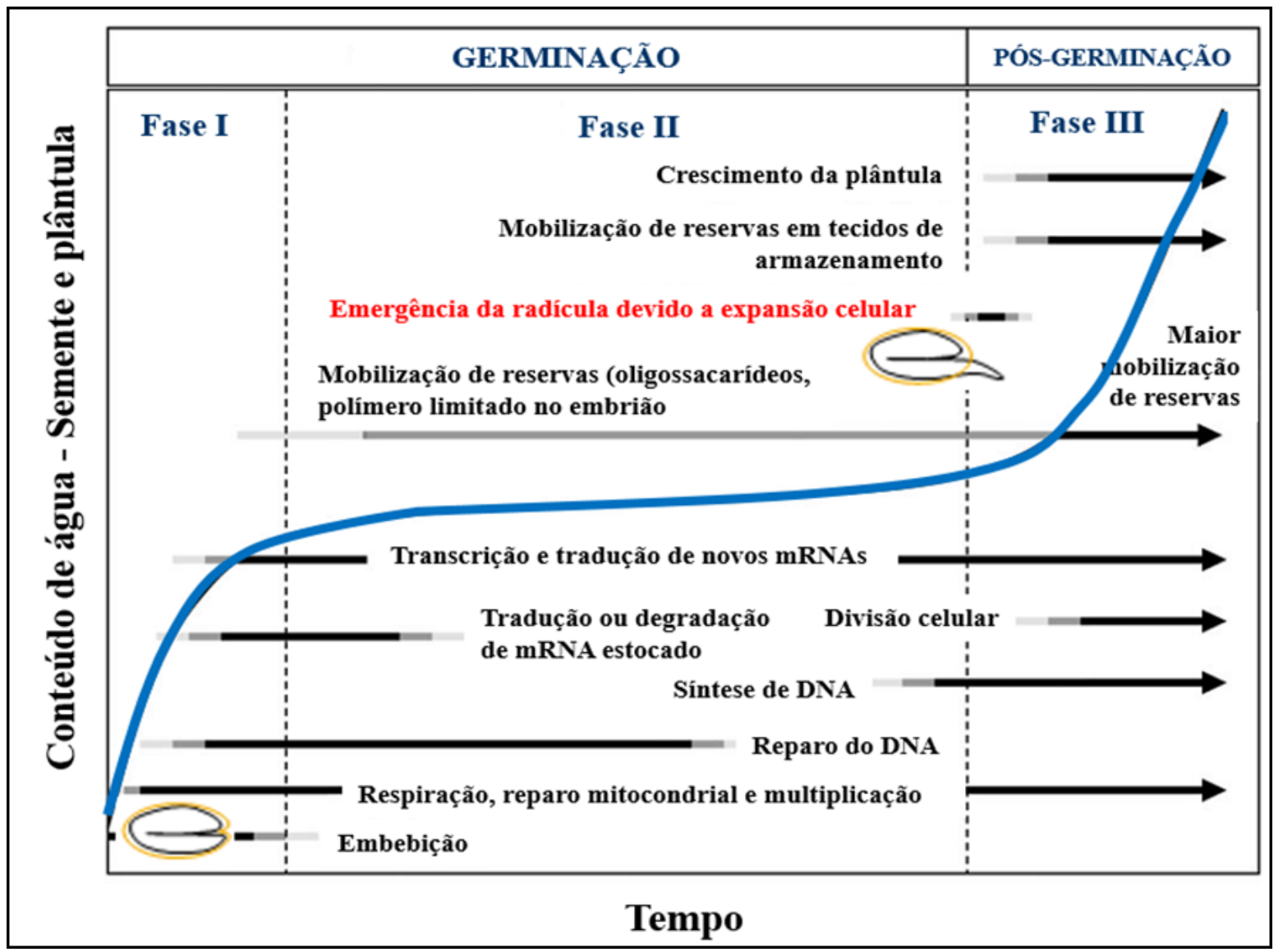

Figura 1. Curso de tempo dos eventos físicos e metabólicos que ocorrem durante a germinação (Fases I e II) e pós-germinação (crescimento inicial da plântula) (Fase III). O tempo para cada um desses eventos ocorrerem varia entre espécies e é influenciado por condições de germinação. A curva mostra o tempo do curso do consumo de água. Adaptado de Nonogaki et al. (2010) e Bove et al. (2001). 


\section{Danos ao DNA}

Os danos ao DNA são comuns e se originam por clivagem espontânea das ligações químicas do DNA por reação com agentes genotóxicos no ambiente (radiação ultravioleta, entre outros), por ação de produtos secundários do metabolismo celular normal (radicais livres na respiração celular), por erros introduzidos pela DNA polimerase durante a replicação (Dunkern et al., 2001; Clancy, 2008). Estes danos induzem a várias respostas celulares que visam à reparação do erro ou até mesmo a ativação do processo de morte celular programada, provavelmente para a eliminação de células com mutações potencialmente catastróficas (Sancar et al., 2004).

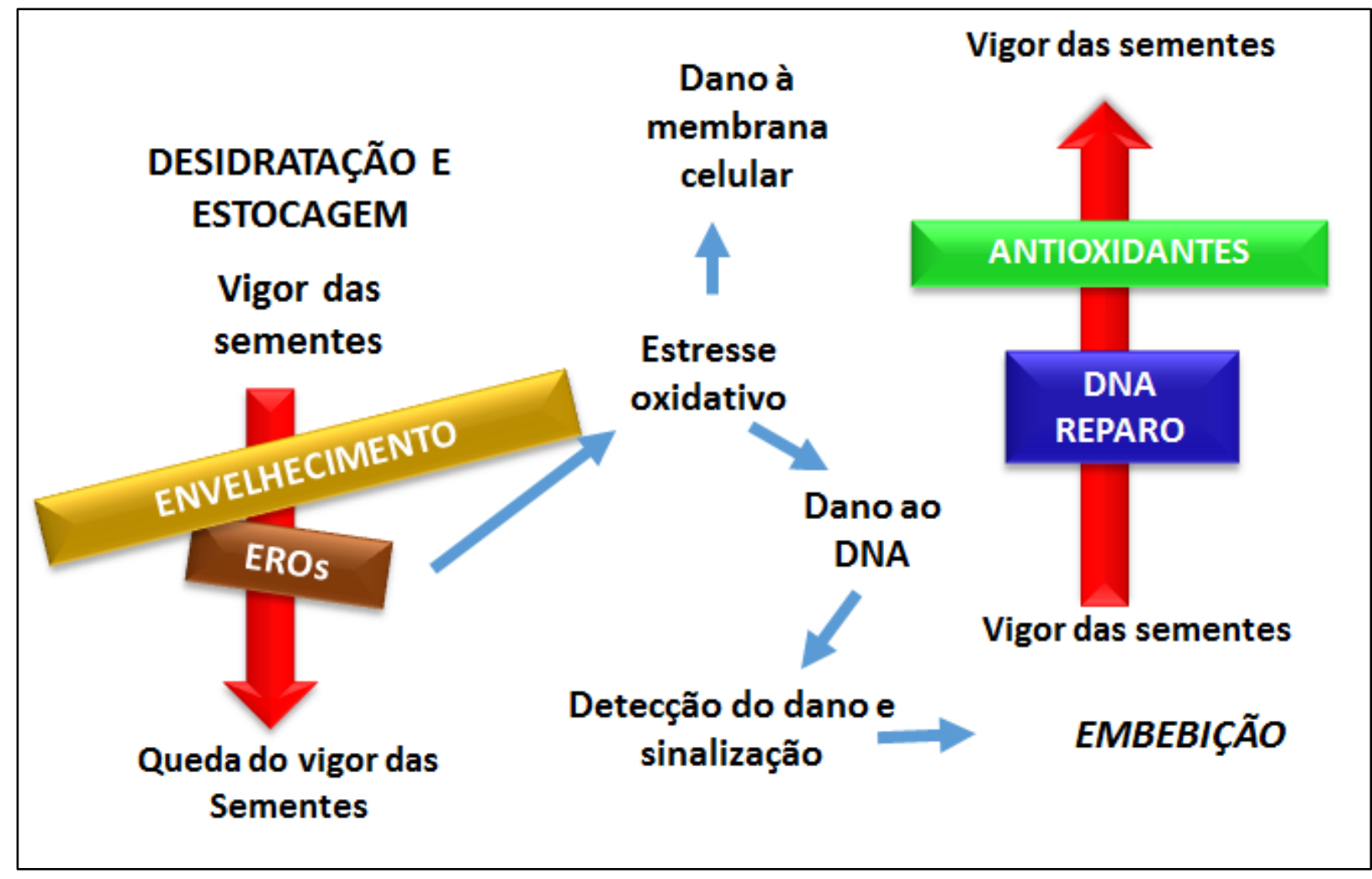

Figura 2. Principais vias que determinam o vigor das sementes. A desidratação e a ação das espécies reativas de oxigênio (EROs) durante o envelhecimento levam a queda do vigor. Durante a embebição, funções antioxidantes e de reparo de DNA são ativadas, restaurando o vigor. Fonte: Adaptado de Ventura et al. (2012).

De forma geral, os danos ao DNA podem ser classificados como danos à fita simples (SSBs - Single strand breaks) e danos à fita dupla (DSBs - Double strand breaks). Os danos do tipo SSB são os mais comuns e tratam-se de descontinuidades em uma das fitas da dupla 
hélice, ocorrendo com frequência em dezenas de milhares de células por dia, devido ao ataque direto de metabólitos intracelulares e a deterioração espontânea do DNA (Caldecott, 2008).

Os danos do tipo DSB, em que ambas as fitas de DNA são danificadas, são os mais críticos, com grande potencial para causar instabilidade genômica (Kozak et al., 2009). Se o maquinário de reparo do DNA falhar, as lesões ao DNA podem levar a morte celular como também a morte do organismo (Sancar et al., 2004). Em sementes os mecanismos de reparo de DNA ocorrem por inserção de nucleotídeos (Figura 3), por recombinação homóloga e por recombinação não homóloga (Figura 4) e são essências para a estabilidade genômica em sementes (Ventura et al., 2012).

No reparo por inserção de nucleotídeos a possibilidade de mudança genética é diminuída, pois a síntese de novos nucleotídeos e baseada na fita complementar intacta do DNA (Figura 3) (Sancar et al., 2004). No reparo por recombinação homóloga mesmo com as duas fitas do DNA danificadas, são sintetizados novos nucleotídeos com base em regiões homólogas das fitas intactas de DNA da outra cromátide irmã do mesmo cromossomo (Figura 3a) (van Gent et al., 2001). Já no reparo por recombinação não homóloga, há maior probabilidade de mudança genética pois não há a síntese de novos nucleotídeos e sim a junção das pontas das fitas de DNA, havendo assim perda de informação genética (Figura 3b). Esse tipo de reparo tem forte potencial para gerar instabilidade genômica (Hastings et al., 2009).

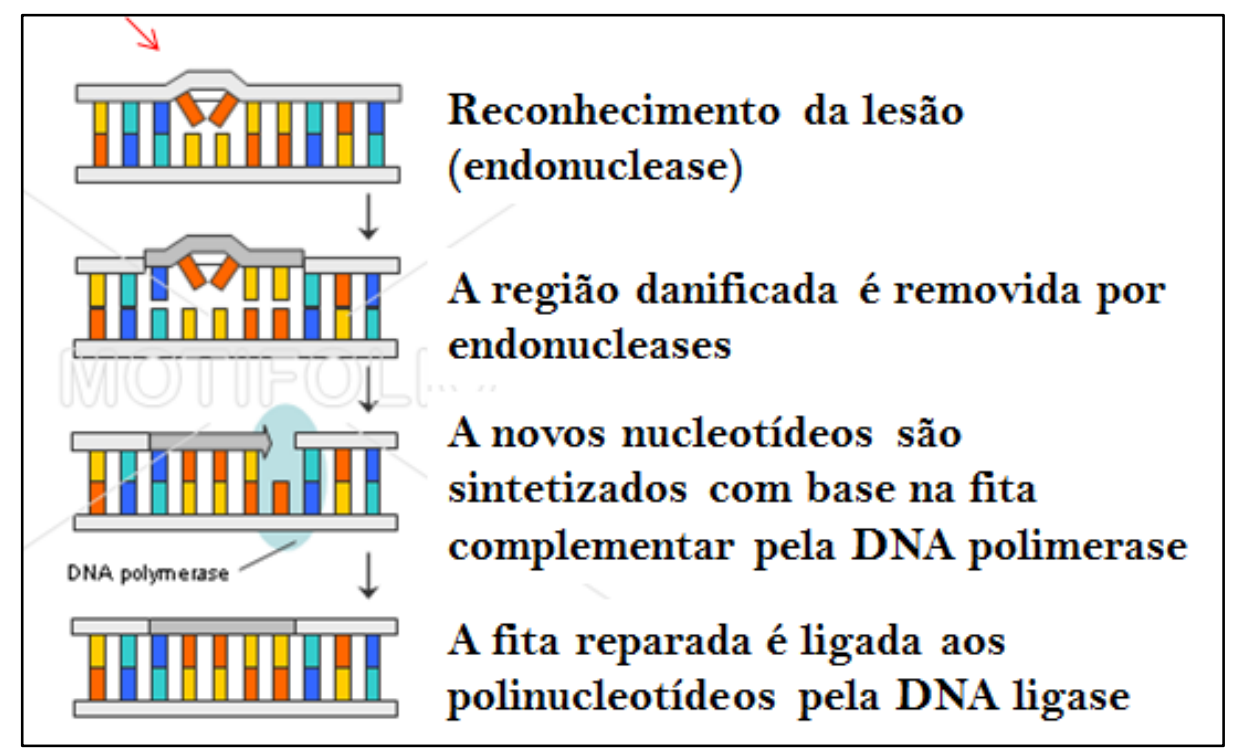

Figura 3. Reparo de dano à fita simples do DNA pelo mecanismo de reparo por inserção de nucleotídeos. Adaptado de http//www.motifolio.com/1021143.html. 


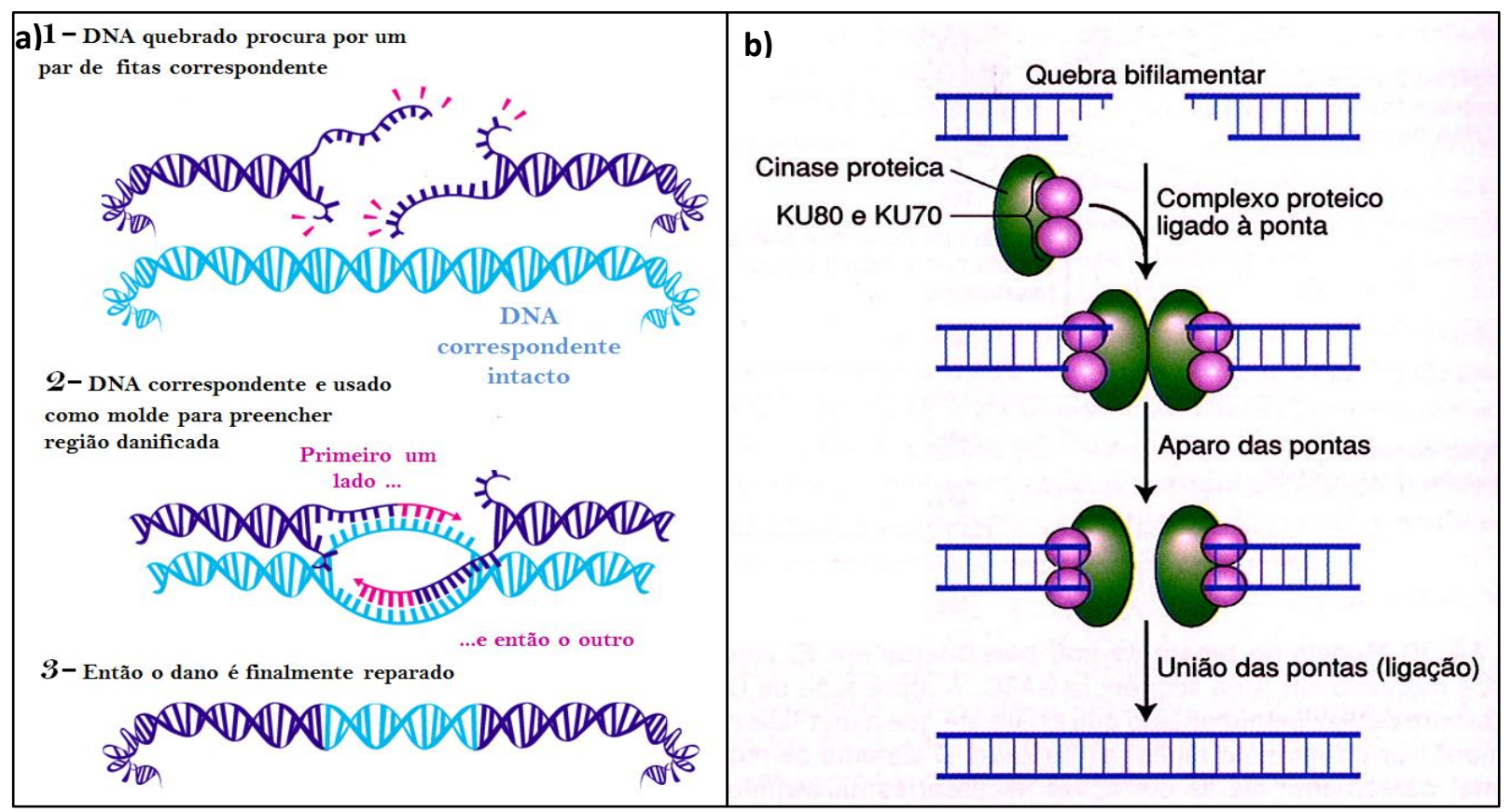

Figura 4. Mecanismos de reparo ao dano à fita dupla do DNA: a) por recombinação homóloga (adaptado de http://scienceblog.cancerresearchuk.org) e b) por recombinação não homologa (fonte : www.ebah.com.br/content/ABAAAAIggAI/mutacaoreparorecombinacao).

\section{Recursos fitogenéticos}

Os recursos fitogenéticos (RFs) representam o material genético de origem vegetal, que contém unidades funcionais de hereditariedade e que possui valor real ou potencial para uso pelo homem (Walter et al., 2005).

Os RFs constituem a base na qual a humanidade subsiste, pois a espécie humana é altamente dependente dos RFs, porque eles constituem a base da segurança alimentar mundial, sendo relacionados à satisfação das necessidades básicas do homem e a solução de vários problemas, como a fome e a pobreza (Jaramillo e Baena, 2002).

Os recursos genéticos são repositórios de alelos envolvidos com a expressão de características de grande importância, como por exemplo, aumento da resistência a estresses bióticos ou abióticos, que garantem a segurança alimentar da população.

A demanda por alimentos aumenta a cada ano, atualmente a população mundial está em torno de sete bilhões e deve chegar a nove bilhões até 2045. Em função disso, ampla diversidade genética precisa estar disponível para o uso, de modo a alimentar a população (Lidder e Sonnino, 2012). 


\section{$\underline{\text { Conservação de Recursos Fitogenéticos }}$}

A conservação efetiva dos recursos fitogenéticos (RFs) requer a preservação de uma ampla amostra da variabilidade genética das espécies alvo para a agricultura, como por exemplo, muitos materiais reprodutivos ou de propagação vegetativa de variedades crioulas, cultivares obsoletas, cultivares atualmente em uso, parentes selvagens e mutantes (Piergiovanni, 2013).

Na conservação ex situ, a conservação das espécies é realizada em suas áreas de ocorrência natural, o que possibilita a conservação de processos ecológicos, como por exemplo, polinização e dispersão de sementes (Cohen et al., 1991; Freitas e Medeiros, 2009). Além disso, esta estratégia também pode oferecer outras vantagens como a continuidade dos processos evolutivos, que são essenciais para mecanismos de adaptação à conservação de comunidades inteiras e a preservação em longo prazo de populações viáveis (Freitas e Medeiros, 2009).

Na conservação ex situ as amostras são preservadas fora de seu ambiente natural, em bancos de germoplasma (Cohen et al., 1991). Neste tipo de conservação existem as seguintes modalidades:

- Coleção ativa - conjunto de amostras ou acessos de germoplasma armazenadas a curto ou médio prazo e mantido para fins de estudo ou distribuição (Jaramillo e Baena, 2002). Visam atender imediatamente a programas de melhoramento genético e de intercâmbio de germoplasma (José, 2010).

- Coleção base - é uma coleção abrangente de acessos conservados em longo prazo, onde a integridade fisiológica e genética é mantida mais próxima possível daquela do acesso quando incluído na coleção. Destina-se a regeneração de coleções ativas.

\section{Bancos de germoplasma}

Germoplasma é a soma total do material genético reprodutivo de uma planta (Veiga e Queiroz, 2015). Os bancos de germoplasma (BGs) destinam-se à preservação da variabilidade genética vegetal existente, abrangendo amostras desde cultivares modernas até as espécies silvestres, das quais os seres humanos dependem para a produção de alimentos, fibras e combustíveis (Mccouch et al., 2012).

A conservação de germoplasma semente tem como vantagens a possibilidade de manutenção de uma grande quantidade de genótipos em um pequeno espaço e em longo prazo. 


\section{Manutenção da viabilidade de sementes estocadas}

Acessos de diferentes espécies têm sido armazenados em câmaras frias de BGs em todo o mundo e no geral ciclos de regeneração são realizados (Parzies et al., 2000). Os intervalos de monitoração dos acessos armazenados dependem da espécie, da viabilidade no início do armazenamento e das condições de armazenamento, mas em média são realizadas a cada 10 anos (Fao, 1994; Upadhyaya et al., 2008; José, 2010).

O monitoramento é feito utilizando-se o teste de germinação, que tem por objetivo determinar o potencial máximo de germinação de um lote de sementes (Brasil, 2009). A germinação de sementes, em teste de laboratório, é definida como a emergência do embrião, demonstrando sua aptidão para produzir uma planta normal sob condições favoráveis de campo (Brasil, 2009).

O teste tetrazólio é outro teste utilizado frequentemente em bancos de germoplasma, em espécies que apresentam alta frequência de sementes que não germinam, mas que parecem viáveis (“duras") durante o teste de germinação, as quais podem estar dormentes. Este teste reflete a atividade das enzimas desidrogenases envolvidas no processo de respiração, permitindo distinguir as partes vivas e mortas da semente (Brasil, 2009; José, 2010). No teste tetrazólio os tecidos vivos apresentam coloração vermelha e os tecidos mortos não ficam corados (Gaspar-Oliveira et al., 2009).

No Banco Genético da Embrapa, as sementes que chegam passam por processo de limpeza, determinação de umidade e viabilidade. Uma vez dentro dos padrões para a incorporação na Coleção Base, as sementes são acondicionadas em envelopes com um código de barra que indica a sua localização na câmara fria, de temperatura entre -18 e $-20^{\circ} \mathrm{C}$ (José, 2010).

\section{Soja (Glycine max (L.) Merr.) e cevada (Hordeum vulgare L.)}

No mundo existem duas famílias de vegetais que contribuem substancialmente para a segurança alimentar humana, a Fabaceae Lindl e a Poaceae Barnhart.

A família Fabaceae Lindl é a terceira maior família de plantas florísticas e inclui leguminosas e oleaginosas de grande importância, como, por exemplo, a soja (Glycine max), o feijão (Phaseolus vulgaris), o amendoim (Arachis hypogaea) e a lentilha (Lens culinaris). Na família Poaceae Barnhart, encontram-se os cereais, como por exemplo, o trigo (Triticum aestivum), o milho (Zea mays), o arroz (Oryza sativa), a cana de açúcar (Saccharum 
officinarum), o sorgo (Sorghum bicolor) e a cevada (Hordeum vulgare) (Paterson et al., 2000).

\section{$\underline{\text { Soja (Glycine } \max (\text { L.) Merr.) }}$}

A soja é uma espécie da família Fabaceae, subfamília Papilionoideae, que possui metabolismo fotossintético do tipo C3 e é uma planta essencialmente autógama, com taxa de cruzamento de menos de 1\% (Hyten et al., 2007; Sage e Zhu, 2011). É considerada uma planta de dias curtos (noites longas) e com grande diversidade de ciclos, mas em geral, os cultivares brasileiros possuem ciclos de 100 a 160 dias (Almeida et al., 1999; Embrapa, 2013; Trentin et al., 2013). Geralmente, a soja é cultivada em latitudes maiores que $30^{\circ}$, onde prevalecem condições de clima temperado, sendo que o Brasil representa uma exceção dentro desse contexto (Almeida et al., 1999).

É uma planta diplóide com 20 cromossomos $(2 n=2 x=40)$, que teve origem na China, onde foi domesticada por volta do século XI A.C, a partir da espécie selvagem Glycine soja e com o transcorrer dos séculos, foi disseminada para outras regiões e países do oriente (Purugganan e Fuller, 2009; Schmutz et al., 2010).

A produção mundial de soja é de 300 milhões de toneladas, com área plantada de 117 milhões de hectares no ano de 2014 (Fao, 2014). Nesse mesmo ano os maiores produtores mundiais foram os Estados Unidos - com 108 milhões de toneladas, o Brasil - com 87 milhões toneladas e a Argentina - com 53 milhões de toneladas (Fao, 2014).

Assim como outras leguminosas, a soja faz associação simbiótica com bactérias e nessa associação a planta proporciona compostos orgânicos às bactérias do gênero Bradyrhizobium e em troca recebe nitrogênio (Hill et al., 2006). Essa associação leva a um menor consumo de fertilizantes nitrogenados no cultivo da soja, o que torna essa planta mais interessante que outros grãos, do ponto de vista ambiental e econômico (Hill et al., 2006).

Seus grãos são ótima fonte proteica (30\% a $42 \%$ em base seca), possuindo todos os aminoácidos essenciais e é uma das principais fontes de proteína na alimentação animal e é frequentemente utilizada como substituta da carne na alimentação humana (Ávila et al., 2007). Além disso, seus grãos são uma boa fonte de óleo, de $15 \%$ a $27 \%$, o qual é composto por 53\% de ácido graxo linoleico (ômega 6), seu óleo é bastante utilizado na alimentação humana, sendo também uma das principais fontes de biocombustíveis (Durrett et al., 2008; Martin et al., 2008; Aldal'in et al., 2012). Os grãos ainda apresentam isoflavonas, compostos fenólicos que podem produzir efeitos favoráveis sobre os sintomas do climatério (Nahás et al., 2003; Barbosa et al., 2006). 
A maior barreira para o consumo da soja como alimento são os sabores indesejáveis, principalmente o beany flavor, aceito em países tradicionalmente consumidores de soja, porém, considerado indesejável ao paladar ocidental (Benassi et al., 2013). Os sabores indesejáveis não estão presentes no grão original e são resultados da ação de enzimas lipoxigenases que oxidam os ácidos graxos poliinsaturados presentes no óleo da semente, gerando compostos carbonílicos voláteis como aldeídos, álcoois e cetonas (Robinson et al., 1995; Cunha et al., 2015). Esses sabores podem ser evitados com o tratamento térmico dos grãos antes do processamento e com o desenvolvimento de cultivares livres de enzimas lipoxigenases (Benassi et al., 2013).

A conscientização sobre os benefícios a saúde relacionados à produção de alimentos a base de soja com menor custo têm proporcionado um aumento no consumo desses produtos em todo mundo, com exceção do Brasil onde esse consumo ainda é incipiente, mesmo o país sendo o segundo maior produtor do grão (Chiarello, 2002; Benassi et al., 2013). Mas esse consumo tem aumentado depois que a indústria nacional adotou novas tecnologias para obtenção de alimentos de soja com melhor qualidade sensorial, como o "leite" de soja que tem sido combinado com suco de frutas (Behrens e Silva, 2004).

A variabilidade genética da soja é mantida em vários bancos genéticos no mundo e dado o alto número de acessos preservados pode-se concluir que a variabilidade disponível é muito grande. Por exemplo, o USDA (United States Department Agricultural) mantém um banco com 32,5 mil acessos de soja (Grin, 2016).

No geral, o armazenamento de sementes a baixa temperatura permite a preservação da viabilidade mantendo a germinação dos acessos em nível razoável (acima de 80\%). Porém, a soja é particularmente sensível às condições de armazenamento, pois algumas características físicas e bioquímicas podem ser alteradas em diferentes graus, dependendo de alguns fatores antes do armazenamento (Marcos Filho et al., 1985; Azevedo et al., 2003; Sam, 2010).

As mudanças nas características da soja durante o armazenamento pode incluir: o escurecimento da superfície, a redução da solubilidade de proteínas, alteração na estrutura de proteínas e peroxidação lipídica (Sam, 2010). Já os fatores que afetam a qualidade da soja durante o armazenamento são: a umidade relativa, a temperatura durante o armazenamento, o tempo de armazenamento e principalmente o teor de água inicial na semente (Kong e Chang, 2009). Por isso, para uma boa conservação das sementes de soja, é recomendável que estas sejam secas a níveis de teores de água abaixo de $12 \%$, para reduzir o risco de deterioração proveniente da respiração e por ataque de fungos (Marcos Filho et al., 1985; Acacio, 1998). A quantidade de óleo nas sementes de soja (15-27\%) a faz susceptível a perda de qualidade, 
devido a processos de deterioração via degradação de lipídeos, quando não armazenada de forma adequada (Alencar et al., 2010).

\section{Cevada (Hordeum vulgare L.)}

A cevada é uma gramínea anual, da família Poaceae, que é considerada uma planta modelo para a tribo Triticeae, que inclui outras espécies agronomicamente importantes, como trigo (Triticum aestivum) e centeio (Secale cereale) (Muñoz-Amatriaín et al., 2013). É uma planta diplóide com sete cromossomos $(2 \mathrm{n}=2 \mathrm{x}=14)$, estritamente autógama com taxa de cruzabilidade de menos de 1\% e com metabolismo fotossintético do tipo C3 (Pourkheirandish e Komatsuda, 2007; Bellucci et al., 2013).

Os grãos são importantes para a dieta humana, pois possuem de 53 a $67 \%$ de amido, de 14 a 25\% de fibras e de 9 a 14\% de proteínas (Oscarsson et al., 1996; Mayer et al., 2007). São utilizados na produção de cerveja, na composição de farinhas ou flocos para panificação, na alimentação animal e como substituto para o café (Badr e El-Shazly, 2012; Mori e Minella, 2012). Ainda apresentam benefícios à saúde, como redução do colesterol LDL (Lia et al., 1995; Shimizu et al., 2008).

O seu ciclo total depende da variedade, localização e data do plantio, por exemplo, no Brasil o ciclo é de aproximadamente 110 dias e na Austrália varia de 105 a 157 dias (Thomas e Fukai, 1995; Amabile, 2008). Foi uma das primeiras culturas domesticadas pelo homem, aproximadamente há 10 mil anos atrás na Mesopotâmia (atualmente a área que compreende Israel e Jordânia) e ocorre na maioria das áreas temperadas (Badr et al., 2000; Badr e ElShazly, 2012; Poets et al., 2015).

É o quarto cereal mais plantado no mundo (50 milhões de hectares), ficando atrás apenas do trigo, milho e arroz, com uma produção mundial de 144 milhões de toneladas (Fao, 2014). No Brasil, a produção está em torno de 251 mil toneladas e concentrada na Região Sul (Fao, 2014). Tem ganhado espaço no Cerrado, a partir de resultados de pesquisa obtidos pela Embrapa Cerrados e Embrapa Trigo que conseguiram adaptar essa cultura às condições edafoclimáticas da região, o que resultou no cultivar BRS 180 (Amabile et al., 2013).

As sementes de cevada colhidas com teores de umidade acima de 13,5\% devem ser secas para que se assegure a qualidade das sementes durante o armazenamento. Caso contrário, sementes com alta umidade podem ser rapidamente contaminadas por fungos (Poulsen et al., 2012). Em sementes de cevada com 14\% de água já é possível o crescimento do fungo Aspergillus spp., sendo A. restrictus e a A. glaucus as espécies que mais 
comprometem a conservação de cevada, pois causam redução do vigor e da germinação, colonizando especialmente o embrião (Lazzari, 2006).

\section{Referências}

Acacio, U. A. Soybean and meal characteristics differ from those of cereal grains, requiring distinct considerations to preserve quality. (1998). Disponível em: < http://www.world-grain.-

com/News/Archive/Soybean\%20handling\%20and\%20storage.aspx $\mathrm{p}=1>$. Acesso em: 15/02/2016.

Aldal'in, H. K. H.; Zhmurko, V.; Avksentyeva, O. (2012). Seed Protein and Oil Content of the Soybean Cultivars under Different Climate Condition (Glycine max (L.) Merr.). Am. Eurasian J. Agric. Environ. Sci, 12 (5) : 603-607.

Alencar, E. R. D. et al. (2010). Influence of soybean storage conditions on crude oil quality. Rev. Bras. Eng. Agríc. Ambient., 14 (3) : 303-308.

Almeida, L. A. D. et al. (1999). Melhoramento da soja para regiões de baixas latitudes. In: Queiroz, M. A.; Goedert, C. O.; Ramos, S. R. R.(Ed.). Recursos Genéticos e Melhoramento de Plantas para o Nordeste brasileiro. Embrapa Semi-árido, Petrolina.

Amabile, R. F. A evolução das pesquisas com a cevada no Brasil. (2008). Disponível em: < http://agrosoft.com/br/?p=36005 >. Acesso em: 15/02/2016.

Amabile, R. F.; Capettini, F.; Faleiro, F. G. (2013). BRS Savanna: new six-rowed malting barley cultivar for irrigated crops in the Brazilian savanna. Crop Breed. Appl. Biotechnol., 13 (2) : 160-163.

Ávila, M. R. et al. (2007). Componentes do rendimento, teores de isoflavonas, proteínas, óleo e qualidade de sementes de soja. Rev. Bras. Sementes, 29 (3) : 111-127.

Azevedo, M. R. D. Q. A. et al (2003). Influência das embalagens e condições de armazenamento no vigor de sementes de gergelim. Rev. bras. eng. agríc. ambient., 7 (3) : 519-524.

Badr, A.; El-Shazly, H. (2012). Molecular approaches to origin, ancestry and domestication history of crop plants: Barley and clover as examples. J. Genet. Eng. Biotechnol., $10,(1): 1-12$.

Badr, A. et al. (2000). On the Origin and Domestication History of Barley (Hordeum vulgare). Mol. Bio. Evol., 17(4) : 499-510.

Barbosa, A. C. L. et al. (2006). Teores de isoflavonas e capacidade antioxidante da soja e produtos derivados. Food Sci. Technol., 26 (4) : 921-926.

Behrens, J. H.; Silva, M. A. A. P. D. (2004). Consumer attitude towards soybean and related products. Food Sci. Technol., 24 (3) : 431-439.

Balestrazzi, A. et al. (2011). Genotoxic stress and DNA repair in plants: emerging functions and tools for improving crop productivity. Plant Cell Rep., 30(3):287-295. 
Balestrazzi, A. et al. (2015). DNA repair and telomere maintenance during seed imbibition: correlation of transcriptional patterns. Telomere and Telomerase, $2: 1$ - 4.

Bellucci, E. et al. (2013). Population structure of barley landrace populations and gene-flow with modern varieties. PloS one, 8 (12) : e83891.

Benassi, V.; Prudencio, S.; Varéa, G. (2013). Tofus de diferentes cultivares de soja: Perfil sensorial e correlação com medidas instrumentais e de composição química Alim. Nutr., Araraquara, 23, (4) : 555-566.

Bewley, J. D. 1997. Seed Germination and Dormancy. The Plant cell, 9 (7) : 1055-1066.

Bohr, V. A. (2002). DNA damage and its processing. Relation to human disease, J. Inherit. Metab. Dis. 25 (3): 215-222.

Bove, J.; Jullien, M.; Grappin, P. (2001). Functional genomics in the study of seed germination. Genome Bio., 3 (1) : 1-5.

Brasil. (2009). Teste de germinação. Regras para análise de sementes. MAPA, Brasília, 399 p.

Caldecott, K. (2008). Single-strand break repair and genetic disease. Nat. Ver. Genet., 9 (8) : $619-631$.

Chiarello, M. D. (2002). A soja e os alimentos funcionais: oportunidades de parcerias em P\&D para os setores público e privado. Rev. Parc. Estratégicas, 7 (15) : 45 - 60.

Clancy, S. (2008). DNA damage e repair: mechanisms for maintaining DNA integrity. Nat. Education, 1 (1): 1 - 4.

Cohen, J. I. et al (1991). Ex situ conservation of plant genetic resources: global development and environmental concerns. Science, 253, (5022) : 866-872.

Cunha, D. S. et al (2015). Soja para consumo humano: Breve abordagem. Agrarian Academy, 2 (3) : 101-113.

Dunkern, T. R.; Fritz, G.; Kaina, B. (2001). Ultraviolet light-induced DNA damage triggers apoptosis in nucleotide excision repair-deficient cells via Bcl-2 decline and caspase3/-8 activation. Oncogene, 20 (42) : 6026-6038.

Durrett, T. P.; Benning, C.; Ohlrogge, J. (2008). Plant triacylglycerols as feedstocks for the production of biofuels. Plant J., 54 (4) : 593-607.

El-Maarouf-Bouteau, H. et al. (2011). DNA alteration and programmed cell death during ageing of sunflower seed. J. Exp. Bot., 62 (14): 5003 - 5011.

Embrapa. (2013).Tecnologias de Produção de Soja - Região Central do Brasil 2014. Embrapa Soja, Londrina, pp 1123-1134.

FAO (1994). Genebank Standards. FAO - International Plant Genetic Resources Institute, Rome, 13 p.

. (2014). FAOSTAT. Disponível em: < http://faostat.fao.org/ >. Acesso em: 28/08/2016. 
Freitas, F. O.; Medeiros, M. B. (2009).The state of in situ management. In: Mariante, A. S.; Sampaio, M. J. A. (Ed.). The state of Brazil's plant genetic resource: second national report: conservation and sustainable utilization for food and agriculture. Embrapa Technological Information, Brasília, pp.53-66.

Gaspar-Oliveira, C. M.; Martins, C. C.; Nakagawa, J. (2009). Concentração da solução de tetrazólio e período de coloração do teste para sementes de mamoneira. Rev. Bras. Sementes, 31 (3) : 38-47.

Golubov, A. et al. (2010). Microsatellite instability in Arabidopsis increases with plant development. Plant physiol., 154 (3) : 1415-1427.

Grin. (2016). GRIN - Germplasm Resources Information Network (Grin - Global Web). Disponível em: < https://npgsweb.arsgrin.gov/gringlobal/taxonomydetail.aspx?id=17711 >. Acesso em: 12/10/2016.

Hastings P. J. et al. (2009). Mechanisms of change in gene copy number. Nat. Rev. Genet. 10: 551-64.

Hill, J. et al. (2006). Environmental, economic, and energetic costs and benefits of biodiesel and ethanol biofuels. Proc Natl Acad., 103 (30) : 11206-11210.

Hyten, D. L. et al. (2007). Highly Variable Patterns of Linkage Disequilibrium in Multiple Soybean Populations. Genetics, 175 (4) : 1937-1944.

Jaramillo, S.; Baena, M. (2009). Ex situ conservation of plant genetic resources: training module. International Plant Genetic Resources Institute, Cali - Colombia, 219 p.

José, S. B. R. (2010). Manual de curadores da germoplasma - Vegetal: Conservação ex situ (Colbase - sementes). Embrapa Recursos Genéticos e Biotecnologia, Brasília, $12 \mathrm{p}$.

Kong, F.; Chang, S. K. C. (2009). Statistical and Kinetic Studies of the Changes in Soybean Quality during Storage as Related to Soymilk and Tofu Making. J. Food Sci., 74 (2) : S81-S89.

Kozak, J. et al. (2009). Rapid repair of DNA double strand breaks in Arabidopsis thaliana is dependent on proteins involved in chromosome structure maintenance. DNA repair, 8 (3) : 413-419.

Lazzari, F. A. (2006). Recebimento, Secagem e Armazenagem de Cevada Cervejeira. Disponível em: < http://www.coolseed.com.br/pt/beneficios/triticale-aveia-cevada-etrigo.html >. Acesso em: 15/02/2016.

Lia, A. et al. Oat beta-glucan increases bile acid excretion and a fiber-rich barley fraction increases cholesterol excretion in ileostomy subjects. Am. J. Clin. Nutr., v. 62, n. 6, p. 1245-51, 1995.

Lidder, P.; Sonnino, A. (2012). Biotechnologies for the Management of Genetic Resources for Food and Agriculture. In: Stephen F. Goodwin, T. F. e Jay, C. D. (Ed.). Advances in Genetics. Cambridge, Academic Press, pp 1-167. 
Marcos Filho, J. et al. (1985). Qualidade fisiológica e comportamento de sementes de soja (Glycine max (L.) Merrill) no armazenamento e no campo. An. Esc. Super. Agric. Luiz de Queiroz, 42 (1) : 194-249.

Martin, C. A. et al. (2008). Fatty acid contents of Brazilian soybean oils with emphasis on trans fatty acids. J. Braz. Chem. Soc., 19 (1) : 117-122.

Mayer, E. et al. (2007). Caracterização nutricional de grãos integrais e descascados de cultivares de cevada. Pesq. Agropec. Bras., 42, (11) : 1635-1640.

Mccouch, S. et al. (2012). Genomics of gene banks: A case study in rice. Am. J. Bot., 99 (2) : 407-423.

Mori, C.; Minella, E. (2012). Aspectos econômicos e conjunturais da cultura da cevada. Documentos on line 139, Embrapa Trigo, Passo Fundo: 28 p. Disponível em: < http://ainfo.cnptia.embrapa.br/digital/bitstream/item/91355/1/2012documentosonline139.-pdf >. Acesso em: 06/10/2015.

Muñoz-Amatriaín, M. et al. (2013). Distribution, functional impact, and origin mechanisms of copy number variation in the barley genome. Genome Bio., 14 (6) : 1 - 17.

Nahás, E. A. P. et al. (2003). Efeitos da isoflavona sobre os sintomas climatéricos e o perfil lipídico na mulher em menopausa. Rev. Bras. Ginecol. Obstet., 25 (5) : 337-343.

Nonogaki, H.; Bassel, G.; Bewley, D. (2010). Germination-Still a mystery. Plant Science, $179(6)$ : 574-581.

Oscarsson, M. et al. (1996). Chemical Composition of Barley Samples Focusing on Dietary Fibre Components. J. Cereal Sci., 24 (2) : 161-170.

Parzies, H. K.; Spoor, W.; Ennos, R. A. (2000). Genetic diversity of barley landrace accessions (Hordeum vulgare ssp. vulgare) conserved for different lengths of time in ex situ gene banks. Heredity, 84 (4) : 476-486.

Paterson, A. H. et al. (2000). Comparative genomics of plant chromosomes. Plant cell, 12 (9) : 1523-1540.

Piergiovanni, A. (2013). Capillary electrophoresis: a useful tool for the management of plant genetic resources. Anal. Bioanal. Chem., 405 (2) : 481-491.

Poets, A. et al. (2015). Barley landraces are characterized by geographically heterogeneous genomic origins. Genome Bio., 16 (1) : 1- 11.

Poulsen, H. D. et al. (2012). High-moisture air-tight storage of barley and wheat improves nutrient digestibility. J. Anim. Sci., 90 (4) : 242-244.

Pourkheirandish, M.; Komatsuda, T. (2007). The importance of barley genetics and domestication in a global perspective. Ann Bot, 100 (5) : 999-1008.

Purugganan, M.; Fuller, D. (2009). The nature of selection during plant domestication. Nature, 457 (7231) : 843-848.

Rajjou, L. et al. (2012). Seed germination and vigor. Annu. Rev. Plant Biol., 63 : 507-533. 
Redfearn, M. et al. (1997). DNA Integrity and Synthesis in Relation to Seed Vigour in Sugar Beet. In: Ellis, R. H.;Black, M.; Murdoch, A. J.; Hong, T. D. (Ed.). Basic and Applied Aspects of Seed Biology. Netherlands, Springer, p.413-420.

Robinson, D. S. et al. (1995). Lipoxygenases and the quality of foods. Food Chem., 54 (1) : 33-43.

Sage, R. F.; Zhu, X. G. (2011). Exploiting the engine of C4 photosynthesis. J. Exp. Bot., 62 (9) : 2989-3000.

Sam, K. C. C. (2010). Storage-Induced Color and Biochemical Changes of Soybeans As Related to Soymilk and Tofu Making. In: (Ed.). Chemistry, Texture, and Flavor of Soy. American Chemical Society, Washington, 113-130 pp.

Sancar, A. et al. (2004). Molecular mechanisms of mammalian DNA repair and the DNA damage checkpoints. Annu. Rev. Biochem., 73 (1) : 39-85.

Schmutz, J. et al. (2010). Genome sequence of the palaeopolyploid soybean. Nature, 463 (7278) : 178-183.

Shimizu, C. et al. (2008). Effect of High $\beta$-Glucan Barley on Serum Cholesterol Concentrations and Visceral Fat Area in Japanese Men-A Randomized, Doubleblinded, Placebo-controlled Trial. Plant Foods Hum. Nutr., 63, (1) : 21-25.

Sibrargen. (2016). Sistema Brasileiro de Informações em Recursos Genéticos. Brasilia, $2016 . \quad$ Disponível em:

https://www.embrapa.br/recursosgeneticosebiotecnologia/pesquisae-

desenvolvimento/recursos-geneticos-e-biotecnologia/bases-de-dados/sibrargen >. Acesso em: 07.01.2016.

Tan, L. et al. (2013). Proteomic insights into seed germination in response to environmental factors. Proteomics, 13 (12) : 1850-1870.

Thomas, T. H.; Fukai, S. (1995). Growth and yield response of barley and chickpea to water stress under three environments in southeast Queensland. I. Light interception, crop growth and grain yield. Crop Pasture Sci., 46, (1) : 17-33.

Trentin, R. et al. (2013). Subperíodos fenológicos e ciclo da soja conforme grupos de maturidade e datas de semeadura. Pesq. Agropec. Bras., 48 (7) : 703-713.

Tuteja, N. et al. (2001). Molecular mechanisms of DNA damage and repair: progress in plants. Crit. Rev. Biochem. M., 36 (4) : 337-397.

Upadhyaya, H. D.; Gowda, C. L. L.; Sastry, D. V. S. S. R. (2008). Plant genetic resources management: collection, characterization, conservation and utilization. J. SAT Agric. Res., $6: 1-16$.

van Gent, D. C.; Hoeijmakers, J. H. J. e R. Kandar. (2001). Chromosomal stability and the DNA double-stranded break connection. Nat. Rev. Genet., 2 (3): 196 - 206.

Veiga, R. F. A e Queiroz, M. A. (2015). Recursos Fitogenéticos: a base da agricultura sustentável no Brasil. UFV, Viçosa -MG, 496 p. 
Ventura, L. et al. (2012). Understanding the molecular pathways associated with seed vigor. Plant Physiol. Biochem., 60: 196-206.

Wallace, S. S. (2002). Biological consequences of free radical-damaged DNA bases. Free Radic. Biol. Med., 33 (1): 1-14.

Walter, B. M. T. et al. (2005). Coleta de germoplasma vegetal: relevância e conceitos básicos. In: Walter, B. M. T. e Cavalcanti, T. B. (Ed.). Fundamentos para a coleta de germoplasma vegeta. Embrapa Recursos Genéticos e Biotecnologia, Brasília, 778 p. 


\section{CAPÍTULO 1. OBTENÇÃO E CARACTERIZAÇÃO FISIOLÓGICA DE LOTES DE SEMENTES DE SOJA E CEVADA ENVELHECIDAS ARTIFICIALMENTE}

\section{RESUMO}

O objetivo desse trabalho foi obter e caracterizar lotes de sementes de cevada e soja em diferentes estágios de deterioração. Foi realizado o envelhecimento acelerado das sementes a $42^{\circ} \mathrm{C}$ a $100 \%$ de UR por diferentes tempos, de $0 \mathrm{~h}$ a $96 \mathrm{~h}$. Os lotes obtidos foram, então, avaliados por meio de testes de germinação e condutividade elétrica (CE), com quatro repetições de 50 sementes para cada teste. As sementes de cevada não envelhecidas (controle) teve $97 \%$ de germinação e a queda foi de 37\% e 73\% após 48 h e 96 h de envelhecimento, respectivamente. O índice de velocidade de germinação da cevada diminuiu de 18,9 para 10,6 e 4,3 para sementes envelhecidas 48 h e 96 h respectivamente. A germinação das sementes envelhecidas artificialmente diminuiu entre $84 \%$ e $94 \%$ em relação ao controle. As sementes de Soja BRS Flora apresentaram germinação inicial de 68\%, abaixo do indicado para inclusão em bancos de germoplasma e comercialização. Para as sementes da soja BRS 7980 a germinação inicial foi de $89 \%$ e diferenças significativas foram observadas entre o controle e as amostras envelhecidas por 48, 72 e 96 h. As amostras obtidas após 6, 12 e 24 h horas não tiveram germinação significantemente menor que o controle. Os valores de CE da cevada variaram de 68,3 a 75,5 $\mu$ S.cm-1.g-1. Porém, não foi observada diferença significativa entre os lotes. A soja cv BRS Flora apresentou valores elevados, acima de $100 \mu$ S.cm-1.g-1, mesmo no lote controle. Para a soja cv BRS 7980 os valores de CE foram mais baixos do que o do cv Flora e variaram entre 36,4 a 70,1 $\mu$ S.cm-1.g-1, apresentando diferença entre os tratamentos controle e os de 48, 72 e $96 \mathrm{~h}$. Com as condições de envelhecimento acelerado adotadas neste estudo foi possível obter lotes de sementes de cevada e soja com diferentes estágios de deterioração.

Palavras-chave: Teste de germinação, condutividade elétrica, envelhecimento acelerado. 


\subsection{INTRODUÇÃO}

Entre os muitos fatores que podem interferir no processo de conservação, a composição química da semente é um deles (Seal et al., 2008). Por exemplo, espécies com maiores teores de óleo na semente possuem um comportamento diferente em conservação, perdendo o poder germinativo mais rápido do que aquelas com menor teor (Mbofung et al., 2013). Portanto, os processos de degradação e consequentemente perda de viabilidade, devem ser estudados nesses dois grupos de espécies.

Os estudos de deterioração dependem da disponibilidade de um número grande de sementes e, se possível, pouca ou nenhuma heterogeneidade genética, o que só pode ser obtido com espécies cultivadas. Levando esses dois fatores em consideração e que soja (Glycine max (L) Merr.) e cevada (Hordeum vulgare L.) são espécies contrastantes com relação ao teor de óleos (Mayer et al., 2007; Aldal'in et al., 2012) e que são espécies com número elevado de acessos em bancos de germoplasma no Brasil (Sibrargen, 2016), tais espécies são adequadas para estudos de deterioração em condições de conservação em longo prazo.

Existem diferentes metodologias para a análise de qualidade de sementes e elas podem ser agrupadas em testes físicos, bioquímicos e fisiológicos. Os testes físicos determinam características das sementes como peso e tamanho. Os testes bioquímicos são considerados testes indiretos e estimam a qualidade da semente, são exemplos o teste tetrazólio, o teste de condutividade elétrica e os testes que medem a atividade de enzimas. E os testes fisiológicos usam parâmetros de germinação e crescimento e podem ser realizados em condições ambientais favoráveis ou adversas (Shaban, 2013).

O teste de germinação é conduzido sob condições favoráveis e tem por objetivo determinar o máximo de germinação de um lote de sementes por meio da classificação das plântulas em normais e anormais (Coimbra et al., 2007; Upadhyaya et al., 2008; Brasil, 2009).

O teste de envelhecimento acelerado foi inicialmente desenvolvido com a finalidade de estimar a longevidade de sementes armazenadas, uma vez que os processos de deterioração ocorridos neste teste são semelhantes aos que ocorrem durante o envelhecimento natural, porém, mais rapidamente (Delouche e Baskin, 1973; Marcos-Filho, 1999; Khan et al., 2003). O teste consiste em acelerar artificialmente a taxa de deterioração das sementes por meio de sua exposição à temperatura e umidade elevadas, que são fatores ambientais preponderantes na intensidade e na velocidade de deterioração (Marcos-Filho, 1999). 
O teste de condutividade elétrica avalia a corrente elétrica por meio de uma ponte de condutividade na solução de embebição e a quantidade de lixiviados passados do interior da célula para o meio exterior, enfim avalia a integridade das membranas celulares (Vieira e Krzyanowski, 1999; Silva et al., 2014). O vigor das sementes está diretamente relacionado à integridade do sistema de membranas celulares (Silva et al., 2014). Quanto maior a deterioração, maior a quantidade de lixiviados, ou seja, sementes com baixo vigor liberam maior quantidade de eletrólitos na solução (Rosa et al., 2000).

O objetivo desse trabalho foi obter lotes de sementes de cevada e soja em diferentes estágios de deterioração, utilizando metodologia de envelhecimento acelerado e caracterizar e comparar bioquímica e fisiologicamente esses lotes.

\subsection{MATERIAIS E MÉTODOS}

Todas as análises deste estudo foram conduzidas no Laboratório de Controle de Qualidade e Fisiologia de Sementes da Embrapa Recursos Genético e Biotecnologia Brasília/DF.

Foram utilizadas sementes de soja do cultivar BRS Flora e BRS 7980, colhidas no ano de 2012 e 2015 respectivamente e sementes de cevada cultivar BRS Caué colhida em 2012. Todas as sementes foram fornecidas pela Empresa Brasileira de Pesquisa Agropecuária (Embrapa).

\subsubsection{Teste de umidade}

Para a determinação dos teores de água (TA\%) das sementes foi realizado o teste de umidade em triplicata pelo o método de estufa a $105^{\circ} \mathrm{C}$ de acordo com as regras de análises de sementes (Brasil, 2009). Foram pesadas 10 sementes de cada repetição em cápsulas de alumínio previamente secas por $1 \mathrm{~h}$ em estufa a $105^{\circ} \mathrm{C}$, resfriada em dessecador e pesadas. As cápsulas com as sementes foram para a estufa onde permaneceram por $24 \mathrm{~h}$, então foram resfriadas em dessecador e pesadas novamente. Os teores de água das sementes foram obtidos por meio da equação abaixo:

$$
T A \%=\frac{100(P-p)}{P-t}
$$

Onde,

- $T A \%=$ teor de água;

- $P=$ peso inicial, peso da cápsula e sua tampa mais o peso da semente úmida;

- $\quad p=$ peso final, peso da cápsula e sua tampa mais o peso da semente seca; e 
- $t=$ tara, peso da cápsula com sua tampa.

O teste de umidade foi realizado antes do tratamento de envelhecimento acelerado e no caso da soja cv BRS 7980 também depois do envelhecimento acelerado e logo antes do teste de condutividade elétrica. Isso porque no decorrer do estudo foi observada a necessidade de também identificar os teores de água nos momentos citados.

\subsubsection{Envelhecimento acelerado}

Com o intuito de se obter sementes com diferentes níveis de deterioração foi realizado um tratamento de envelhecimento acelerado de acordo com metodologia proposta por Marcos-Filho (1999). As sementes de cevada estavam com 5,5 a 6,5\% de água antes do tratamento de envelhecimento acelerado, as da soja BRS Flora com 4,7 a 4,9\% e as da soja BRS 7980 com $7,6 \%$.

$\mathrm{O}$ envelhecimento acelerado foi conduzido em caixas de plástico tipo "gerbox" (11 x $11 \times 3 \mathrm{~cm}$ ). Para cada gerbox, aproximadamente 300 sementes de cevada e 200 de soja foram dispostas em uma tela metálica de forma uniforme dentro da caixa plástica contendo $40 \mathrm{~mL}$ de água destilada (Figura 1.1). No total foram envelhecidas artificialmente 1200 sementes de cevada, 800 sementes da soja cv BRS Flora e 1600 sementes da soja cv. BRS 7980.

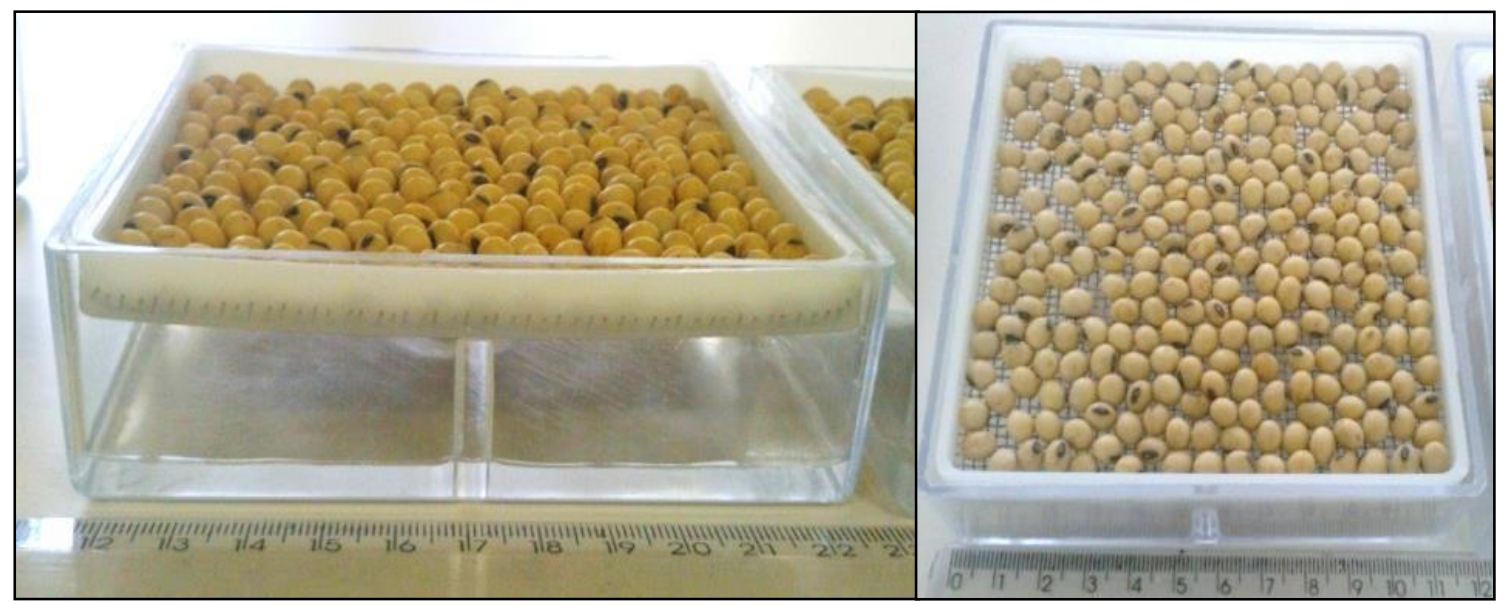

Figura 1. 1. Sementes de soja preparadas para o envelhecimento acelerado em gerbox com 40 $\mathrm{mL}$ de água. Foto: Renata M. Lopes.

Em seguida as tampas das caixas foram colocadas sobre as mesmas e as caixas transportadas cuidadosamente, para que a água abaixo da tela não atingisse as sementes, ate a câmara BOD (biochemical oxygen demand), onde permaneceram por diferentes tempos a $42^{\circ} \mathrm{C}$ e $100 \%$ de umidade relativa (UR\%).

Os tempos de envelhecimento foram: 
- 0 h, 48 h e 96 h para cevada;

- 0 h, 24 h e 48 h para soja cv BRS Flora; e

- $\quad 0$ h, 6h, 12 h, 24 h, 48 h, 72 h e 96 h para a soja cv BRS 7980.

Os tempos de envelhecimento acelerado da soja BRS 7980 fora diferentes da soja BRS Flora, pois esta última tinha poucas sementes e sementes com baixa qualidade inicial. E, ao longo do estudo foi percebida a necessidade de lotes de sementes com germinação parecidas, mas que provavelmente o teste de germinação não detectaria diferenças entre eles.

As sementes controles, as quais não passaram por envelhecimento acelerado, foram mantidas em câmara fria $\left(30 \%\right.$ UR e $\left.10^{\circ} \mathrm{C}\right)$ até o fim do tratamento de envelhecimento acelerado. Após o envelhecimento, uma parte das sementes de todos os lotes, incluindo o controle, foi destinada ao teste de germinação e ao teste de condutividade elétrica. As demais sementes foram secas em câmara de secagem $\left(22^{\circ} \mathrm{C}\right.$ e $15 \%$ UR) até valores de umidade entre 4,7 a $6,5 \%$ de água e estocadas $\left(-20^{\circ} \mathrm{C}\right)$ até o momento das análises moleculares e citogenéticas.

\subsubsection{Teste de germinação e índice de velocidade de germinação}

Para se avaliar a germinação dos lotes das sementes foi realizado o teste de germinação. Para o cv BRS 7980 da soja foi realizado o teste de germinação também após a secagem das sementes e antes do armazenamento, para se averiguar se a secagem causou algum dano. O teste foi conduzido com quatro repetições de 50 sementes cada, em substrato papel toalha tipo germitest umedecido com água destilada na proporção de 2,5 vezes a massa do papel seco (Figura 1.2).

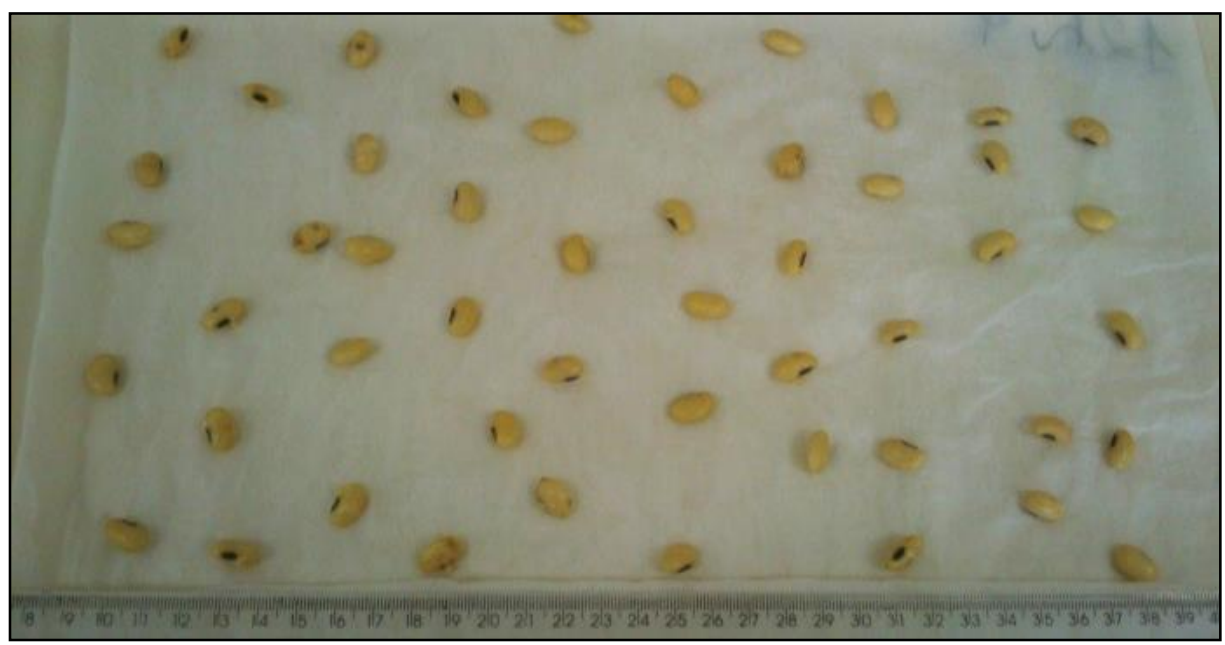

Figura 1.2. Sementes de soja dispostas em papel germitest para o teste de germinação. Foto: Renata M. Lopes. 
Os rolos foram mantidos em saco plástico dentro da câmara tipo BOD, a temperatura de $25^{\circ} \mathrm{C}$. Aos quatro e sete dias (cevada) e aos cinco e oitos dias (soja) do teste foram avaliadas as porcentagens de plântulas normais e anormais, sementes mortas e não germinadas e os resultados expressos em porcentagem média das repetições (Brasil, 2009).

Em conjunto com o teste de germinação foi calculado o índice de velocidade de germinação. As plântulas normais foram computadas diariamente durante o período de contagem de cada espécie avaliada até a estabilização da contagem. O IVG foi determinado de acordo com a fórmula abaixo, proposta por Maguire (1962):

$$
I V G=\frac{G 1}{N 1}+\frac{G 2}{N 2}+\ldots+\frac{G n}{N n}
$$

Onde:

- $\quad I V G=$ índice de velocidade de germinação;

- $G 1, G 2, \ldots G n$ = número de plântulas normais, computadas na primeira contagem, segunda contagem,..., última contagem; e

- $\quad N 1, N 2, \ldots, N n=$ número de dias de semeadura à primeira, segunda,... , última contagem.

\subsubsection{Teste de condutividade elétrica}

$\mathrm{O}$ teste de condutividade elétrica (CE) foi realizado de acordo com Vieira e Krzyzanowski (1999). Após o tratamento de envelhecimento acelerado, as sementes destinadas à condutividade elétrica permaneceram na bancada sobre papel germitest over night para o equilíbrio da umidade das sementes. As sementes controle, as quais não passaram por envelhecimento, não passaram por esse processo, apresentando 7,6\% de teor de agua. As sementes controle permaneceram em câmara fria até o momento da análise.

O teste foi realizado com quatro repetições de 50 sementes cada. Cada repetição de cada lote de sementes foi pesada e imersa em $75 \mathrm{~mL}$ de água destilada em um copo descartável de $200 \mathrm{~mL}$, onde permaneceram por $24 \mathrm{~h}$, a $25^{\circ} \mathrm{C}$ em câmara de germinação tipo BOD. Antes da imersão das sementes foi realizada a leitura da CE da água. Após o período de $24 \mathrm{~h}$ foi realizada a leitura da CE de cada repetição com auxílio de condutivímetro (Digimed DM31). Os resultados foram obtidos por meio da equação abaixo e expressados em $\mu \mathrm{S} . \mathrm{cm}^{-1} . \mathrm{g}^{-}$ ${ }^{1}$ de sementes: 


$$
C E=\frac{V L 2-V L 1}{P S}
$$

Onde:

- $C E=$ condutividade elétrica;

- $\quad V L 2$ = valor da segunda leitura após 24 h da imersão das sementes;

- $V L 1$ = valor da leitura da condutividade elétrica da água antes da imersão das sementes; e

- $P S=$ peso das sementes antes da imersão.

Para as sementes de soja cv BRS 7980, para as quais foram obtidos os valores dos teores de água no momento do teste de $\mathrm{CE}$, foi utilizada uma equação proposta por Vieira $e t$ al. (2002) para a correção dos resultados de CE das sementes de soja para um único teor de água, de 13\%, conforme a equação abaixo:

$$
C E=[0,33227+0,05115(T A)] \times C E O
$$

Onde:

- $\quad C E=$ condutividade elétrica;

- $T A=$ teor de água observado nas sementes \%; e

- $C E O=$ condutividade elétrica observada.

Essa correção dos teores de água para $13 \%$ é para se evitar que ocorram erros devido a diferentes teores de água (TA) nos lotes das sementes, o que pode influenciar os resultados deste teste. O outro cultivar não passou por essa correção, pois não foram obtidos os teores de água no momento do teste de $\mathrm{CE}$, por que até então não tinha sido observada essa necessidade. Já para cevada além de não se ter os TAs no momento da CE, também não há na literatura uma equação de correção do TA proposta para essa espécie.

\subsubsection{Análise de dados}

$\mathrm{O}$ delineamento experimental foi inteiramente casualizado com quatro repetições. A normalidade dos dados foi avaliada pelo teste de Anderson - Darling $(p<0,05)$. Para grupos de amostras que apresentaram distribuição normal foi realizada análise de comparação das médias pelo teste de Tukey $(p<0,05)$ e para as amostras que não apresentaram distribuição normal foi realizado o teste não paramétrico de Kruscal-Wallis $(p<0,05)$. Para averiguar 
diferenças na germinação antes e após a secagem das sementes da soja cv BRS 7980 para o armazenamento, foi realizado o teste de Wilcoxon $(p<0,05)$. Toda a análise de dados foi realizada no programa Excel com suplementação do software ActionStat ${ }^{\circledR}$ (http://www.portalaction.com.br).

\subsection{RESULTADOS E DISCUSSÃO}

\subsubsection{Cevada}

O envelhecimento acelerado foi eficiente, provocando queda na germinação (G\%) das sementes de cevada (Tabela 1.1). As sementes controle apresentaram 97\% de germinação e a redução foi de 37\% e $73 \%$ após 48 h e 96 h de envelhecimento, respectivamente. O índice de velocidade de germinação (IVG) diminuiu de 18,9 do controle para 10,6 e 4,3 para sementes envelhecidas $48 \mathrm{~h}$ e $96 \mathrm{~h}$ respectivamente.

Samarah e Al-kofahi (2008), obtiveram diminuição na germinação entre lotes de sementes de cevada envelhecidas nas mesmas condições deste estudo, apenas a partir de $96 \mathrm{~h}$ de envelhecimento. Neste caso a germinação diminuiu de $94 \%$ no controle para $78 \%$ no tratamento 96h, uma redução de apenas $17 \%$. Isso pode ser devido à variação genética entre o acesso utilizado nesse estudo e o utilizado pelos referidos autores.

Já Akhter et al. (1992), avaliaram o efeito do envelhecimento natural sobre as sementes de cevada estocadas em dessecador por 1, 7 e 10 anos. As reduções na germinação foram mais discretas, na amostra com um ano de armazenamento a germinação foi de $93 \%$, reduzindo para $39 \%$ para as amostras com sete anos de armazenamento e $22 \%$ para as amostras com 10 anos de armazenamento.

Tabela 1.1. Valores médios das análises fisiológicas da cevada seguido do desvio padrão.

\begin{tabular}{cccc}
\hline Tratamentos & G\% & IVG & CE $\left(\mu S \cdot \mathrm{cm}^{-1} \cdot \mathrm{g}^{-1)}\right.$ \\
\hline Controle & $97 \pm 3,0^{\mathrm{a}}$ & $18,9 \pm 0,6^{\mathrm{a}}$ & $75,5 \pm 4,1^{\mathrm{a}}$ \\
$48 \mathrm{~h}$ & $61 \pm 3,6^{\mathrm{b}}$ & $10,6 \pm 0,9^{\mathrm{b}}$ & $68,3 \pm 2,6^{\mathrm{a}}$ \\
$96 \mathrm{~h}$ & $26 \pm 3,7^{\mathrm{c}}$ & $4,3 \pm 0,5^{\mathrm{c}}$ & $72,3 \pm 3,3^{\mathrm{a}}$
\end{tabular}

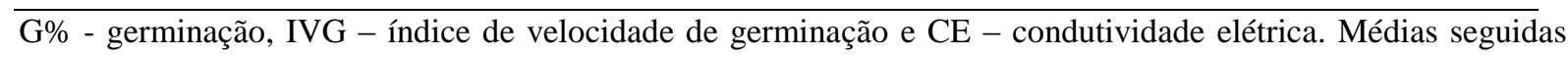
por mesma letra em uma mesma coluna não diferem de acordo com o teste de Tukey $(\mathrm{p}<0.05)$.

Os valores de condutividade elétrica da cevada variaram de 68,3 a 75,5 $\mu$ S.cm-1.g-1 (Tabela 1.1). Porém, não foi observada diferença significativa entre os lotes. O teste de CE não foi suficientemente sensível para detectar diferenças entre os lotes de sementes de cevada. Samarah e Al-Kofahi (2008), observaram pouca ou nenhuma variação na condutividade 
elétrica entre lotes de sementes de cevada envelhecidas por diferentes tempos. Houve aumento significativo da condutividade elétrica apenas após $124 \mathrm{~h}$ de envelhecimento. Spinola et al. (2000), também não observaram diferenças entre lotes de sementes de milho envelhecidas artificialmente por diferentes tempos, de $0 \mathrm{~h}$ a $120 \mathrm{~h}$ a $41^{\circ} \mathrm{C}$. Os autores mostraram variações de apenas 1 a $3 \mu$ S.cm-1.g-1 de condutividade elétrica entre os diferentes tempos de envelhecimento para as sementes de milho.

Essa não variação nos valores de condutividade elétrica entre os diferentes tempos de envelhecimento de cevada pode ser devido ao fato de que o tempo de imersão de $24 \mathrm{~h}$ tenha sido suficiente para reestruturar o sistema de membranas, não sendo detectando diferenças entre os tratamentos.

\subsubsection{Soja}

As sementes de Soja BRS Flora apresentaram germinação inicial de 68\%, abaixo do indicado para inclusão em bancos de germoplasma e comercialização. A germinação das sementes envelhecidas diminuiu $84 \%$ e $94 \%$ em relação ao controle. Foi observada diferença significativa entre as amostras pela análise do IVG (Tabela 1.2), que apresentou os seguintes valores: 3,8 para as sementes controles 2,4 para as sementes envelhecidas por 24 h e 0,7 para as de $48 \mathrm{~h}$ de envelhecimento acelerado.

Os valores de condutividade elétrica nas sementes de Soja cv BRS Flora foram elevados, acima de $100 \mu$ S.cm-1.g-1, mesmo nas sementes controle, diferindo dos dados da literatura para soja de boa qualidade, os quais variam de 47 a $84 \mu \mathrm{S} . c m-1 . g-1$ (Vieira et al., 2002; Rodrigues et al., 2006). Esses dados confirmam a baixa qualidade das sementes da soja cv Flora indicado no teste de germinação. Mesmo assim, houve uma correlação negativa entre a condutividade elétrica observada para as sementes de Soja cv BRS Flora e a germinação $(\mathrm{G} \%)$, isto é, aumentou significativamente à medida que o valor da $\mathrm{G} \%$ diminuía e este teste detectou diferença entre os lotes de sementes envelhecidas. Os valores variaram de 173,8 $\mu$ S.cm-1.g-1 para o tratamento controle a 256,0 $\mu$ S.cm-1.g-1 para o lote envelhecido por $48 \mathrm{~h}$ (Tabela 1.2). 
Tabela 1.2. Valores médios das análises fisiológicas da soja cv BRS Flora, seguido do desvio padrão.

\begin{tabular}{cccc}
\hline Tratamentos & G\% & IVG & CE $\left(\mu S . \mathrm{cm}^{-1} \cdot \mathrm{g}^{-1)}\right.$ \\
\hline Controle & $68 \pm 5,0^{\mathrm{a}}$ & $13,8 \pm 1,1^{\mathrm{a}}$ & $173,8 \pm 9,3^{\mathrm{a}}$ \\
$24 \mathrm{~h}$ & $11 \pm 1,0^{\mathrm{b}}$ & $2,4 \pm 0,2^{\mathrm{b}}$ & $236,4 \pm 4,6^{\mathrm{b}}$ \\
$48 \mathrm{~h}$ & $4 \pm 3,2^{\mathrm{c}}$ & $0,7 \pm 0,5^{\mathrm{c}}$ & $256,0 \pm 7,5^{\mathrm{c}}$
\end{tabular}

G\% - germinação, IVG - índice de velocidade de germinação e CE - condutividade elétrica. Médias seguidas por mesma letra em uma mesma coluna não diferem de acordo com o teste de Kruscal-Wallis $(\mathrm{p}<0.05)$.

Para as sementes da soja BRS 7980, a G\% inicial era de 89\% e diferenças significativas foram observadas entre o controle e as amostras envelhecidas por 48, 72 e $96 \mathrm{~h}$ (Tabela 1.3). As amostras obtidas após 6, 12 e 24 h horas não tiveram G\% significantemente menor do que o controle. Essas amostras de sementes envelhecidas por 6, 12 e $24 \mathrm{~h}$, apesar de estarem mais deterioradas que as sementes controle, apresentam germinação igual às sementes controle. Provavelmente, houve alterações na integridade dessas sementes, porém o teste de germinação não detectou isso. Daí a necessidade de se explorar outras metodologias para complementação ao teste de germinação. O IVG das sementes da soja BRS 7980 variou de 15,0 a 1,4 para os tratamentos controle e 96h, respectivamente (Tabela 1.3).

Para as sementes da soja cv BRS 7980, os valores de CE foram mais baixos do que o do cv Flora e variaram entre 36,4 a 70,1 $\mu$ S.cm-1.g-1 (Tabela 1.3). Houve diferença entre os tratamentos controle e os de 48, 72 e 96 h. Apesar do teste de germinação não detectar diferenças de integridade entre as sementes envelhecidas por $0,6,12$ e $24 \mathrm{~h}$, o teste de condutividade elétrica mostrou uma tendência de diferenciar melhor as sementes controle das demais (Tabela 1.3). 
Tabela 1.3. Valores médios das análises fisiológicas da Soja cv BRS 7980, seguido do desvio padrão no decorrer do envelhecimento acelerado.

\begin{tabular}{cccc}
\hline Tratamentos & G\% & IVG & CE $(\mu$ S.cm-1.g-1) \\
\hline Controle & $89 \pm 3,6^{\mathrm{a}}$ & $15,0 \pm 0,9^{\mathrm{a}}$ & $36,4 \pm 5,4^{\mathrm{a}}$ \\
$6 \mathrm{~h}$ & $86 \pm 8,6^{\mathrm{a}}$ & $14,5 \pm 1,6^{\mathrm{a}}$ & $58,8 \pm 8,2^{\mathrm{b}}$ \\
$12 \mathrm{~h}$ & $87 \pm 3,8^{\mathrm{a}}$ & $14,7 \pm 1,1^{\mathrm{a}}$ & $46,8 \pm 5,8^{\mathrm{ab}}$ \\
$24 \mathrm{~h}$ & $85 \pm 5,0^{\mathrm{a}}$ & $14,1 \pm 0,7^{\mathrm{a}}$ & $43,6 \pm 5,1^{\mathrm{ab}}$ \\
$48 \mathrm{~h}$ & $59 \pm 3,8^{\mathrm{b}}$ & $9,1 \pm 0,8^{\mathrm{b}}$ & $52,6 \pm 4,2^{\mathrm{bc}}$ \\
$72 \mathrm{~h}$ & $52 \pm 1,7^{\mathrm{b}}$ & $6,9 \pm 0,3^{\mathrm{b}}$ & $59,6 \pm 19,0^{\mathrm{bc}}$ \\
$96 \mathrm{~h}$ & $12 \pm 0,9^{\mathrm{c}}$ & $1,4 \pm 0,0^{\mathrm{c}}$ & $70,1 \pm 12,6^{\mathrm{c}}$ \\
\hline
\end{tabular}

G\% - germinação, IVG - índice de velocidade de germinação e CE - condutividade elétrica. Médias seguidas por mesma letra em uma mesma coluna não diferem de acordo com o teste de Kruscal-Wallis ( $<<0.05$ ).

Para a soja cv BRS 7980 foram averiguados os teores de água (TA) ao longo do envelhecimento. Essa análise não foi realizada para a soja cv BRS Flora e para as sementes de cevada, pois quando foi observada essa necessidade o envelhecimento dessas amostras já havia sido realizado. Os teores de água da soja cv BRS 7980 tiveram aumento aproximadamente linear em função do tempo de envelhecimento, com correlação de $\mathrm{R}^{2}=$ 0,95. Os TAs aumentaram de 7,6\% antes do envelhecimento para $11,4 \%$ depois de $6 \mathrm{~h}, 15,3 \%$ depois de $12 \mathrm{~h}, 18,5 \%$ depois de $24 \mathrm{~h}, 22,5 \%$ depois de $48 \mathrm{~h}, 31,1 \%$ depois de $72 \mathrm{~h}$ e $32,6 \%$ depois de 96 h (Figura 1.3). Os TAs após 48 h e 72 h estão próximos dos encontrados na literatura após envelhecimento de sementes de soja a $42^{\circ} \mathrm{C}$ em BOD (de 26,4\% e 30,9\%, respectivamente) (Scappa-Neto et al., 2000; Dutra e Vieira, 2004).

Após a secagem das amostras de soja BRS 7980 (para serem armazenadas a $-20^{\circ} \mathrm{C}$ ), foi realizado novo teste de germinação para verificar se houve danos às sementes devido à secagem necessária para o armazenamento a $20^{\circ} \mathrm{C}$ até o momento das análises moleculares. Houve diferença na germinação após a secagem das sementes envelhecidas por $72 \mathrm{~h}$, mas os demais tratamentos permaneceram iguais (Tabela 1.4). Já o IVG apresentou valores mais baixos para todos os tratamentos em relação ao IVG de antes da secagem, com exceção do 48h. Isso indica uma germinação mais lenta que poderá refletir em mau desenvolvimento da plântula. Então, é provável que a secagem tenha causado danos às sementes, mas não perceptíveis na germinação. 


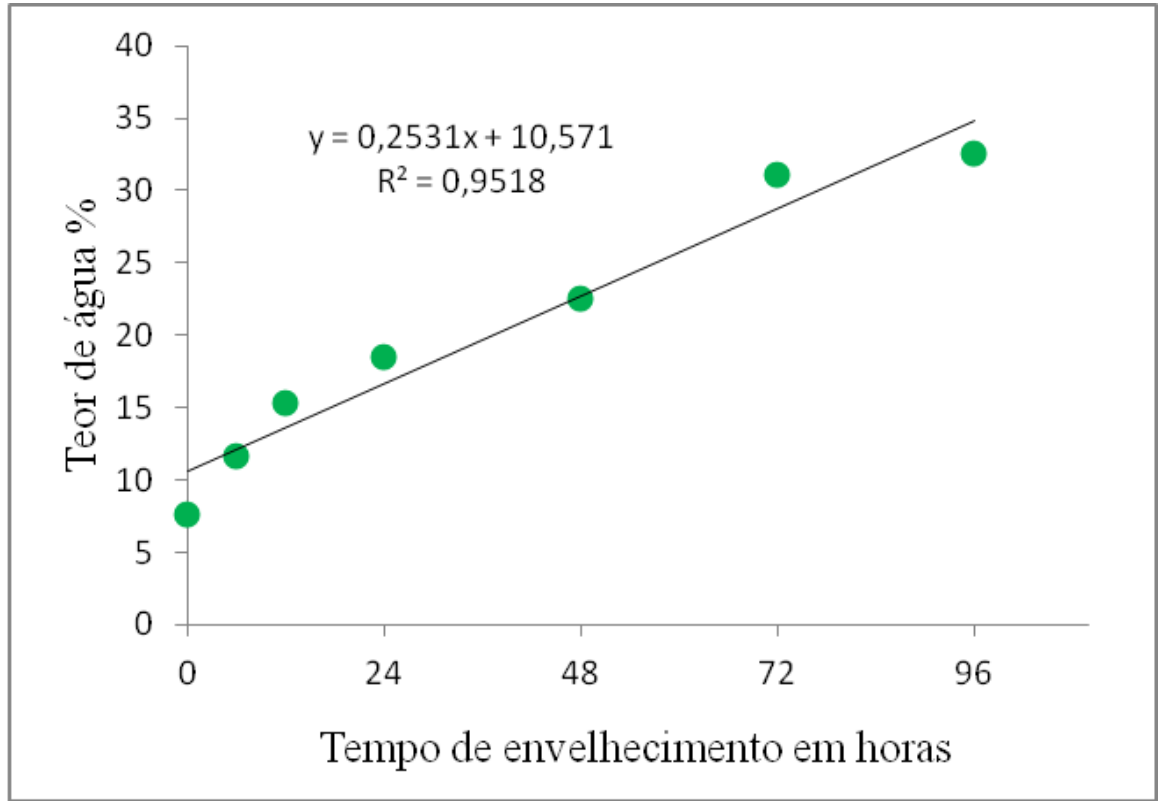

Figura 1.3. Teor de água nas sementes de soja BRS 7980 no decorrer do envelhecimento acelerado a $42^{\circ} \mathrm{C}$. Houve aumento aproximadamente linear no teor de água das sementes em função do tempo de envelhecimento.

Tabela 1.4. Comparação da germinação e o índice de velocidade de germinação da Soja cv BRS 7980, logo após o envelhecimento e após a secagem das amostras para o armazenamento.

\begin{tabular}{ccccc}
\hline Tratamentos & G\% & G\%2 & IVG1 & IVG2 \\
\hline Controle & $89 \pm 3,6^{\mathrm{a}}$ & $86 \pm 6,7^{\mathrm{a}}$ & $13,1 \pm 0,5^{\mathrm{a}}$ & $10,0 \pm 0,9^{\mathrm{a} *}$ \\
$6 \mathrm{~h}$ & $86 \pm 8,7^{\mathrm{a}}$ & $84 \pm 9,6^{\mathrm{a}}$ & $12,8 \pm 1,4^{\mathrm{a}}$ & $9,0 \pm 0,9^{\mathrm{a} *}$ \\
$12 \mathrm{~h}$ & $84 \pm 5,0^{\mathrm{a}}$ & $84 \pm 5,6^{\mathrm{a}}$ & $12,8 \pm 0,8^{\mathrm{a}}$ & $8,7 \pm 0,6^{\mathrm{a} *}$ \\
$24 \mathrm{~h}$ & $85 \pm 5,0^{\mathrm{a}}$ & $85 \pm 3,8^{\mathrm{a}}$ & $12,7 \pm 1,0^{\mathrm{a}}$ & $9,5 \pm 0,2^{\mathrm{a} *}$ \\
$48 \mathrm{~h}$ & $59 \pm 3,8^{\mathrm{b}}$ & $71 \pm 11,6^{\mathrm{a}}$ & $8,3 \pm 0,7^{\mathrm{b}}$ & $6,4 \pm 1,2^{\mathrm{b}}$ \\
$72 \mathrm{~h}$ & $52 \pm 1,7^{\mathrm{b}}$ & $35 \pm 6,1^{\mathrm{b} *}$ & $6,8 \pm 0,2^{\mathrm{b}}$ & $2,4 \pm 0,4^{\mathrm{c} *}$ \\
$96 \mathrm{~h}$ & $12 \pm 0,9^{\mathrm{c}}$ & $11 \pm 4,1^{\mathrm{c}}$ & $1,5 \pm 0,0^{\mathrm{c}}$ & $0,7 \pm 0,3^{\mathrm{c} *}$
\end{tabular}

G\% - germinação, IVG - índice de velocidade de germinação. 1 - antes da secagem e 2 - após secagem das sementes. Médias seguidas por mesma letra em uma mesma coluna não diferem de acordo com o teste de Kruscal-Wallis $(\mathrm{p}<0.05)$. Linhas com asterisco indica diferença em relação ao antes e depois da secagem de acordo com o teste de Wilcoxon $(\mathrm{p}<0.05)$. 


\subsection{CONCLUSÃO}

O teste de germinação e o Índice de velocidade de germinação diferenciaram todos os lotes de sementes envelhecidas da cevada e soja cv BRS Flora, não diferenciando apenas as sementes da soja cv BRS 7980 envelhecidas de 0 às 24h.

O teste de condutividade elétrica não foi sensível para detectar diferenças entre os lotes de sementes envelhecidas de cevada. Mas, foi sensível para as sementes de soja e apresentou uma tendência a separar melhor as sementes controle da cv BRS 7980 das demais amostras envelhecidas.

As condições de envelhecimento acelerado adotadas neste estudo foram adequadas para a obtenção de amostras de soja e cevada com diferentes estágios de deterioração e os testes fisiológicos empregados foram eficientes para a caracterização do material, os quais foram utilizados para os testes moleculares e citogenéticos descritos nos próximos capítulos.

\subsection{REFERÊNCIAS}

Akhter, F. N. et al. (1992). Aging effect of wheat and barley seeds upon germination mitotic index and chromosomal damage. J. Islamic Acad. Sci., 5 (1): 44-48.

Aldal'in, H. K. H.; Zhmurko, V.; Avksentyeva, O. (2012). Seed Protein and Oil Content of the Soybean Cultivars under Different Climate Condition (Glycine max (L.) Merr.). Amer-Eurasian J Agri \& Environ Sciences, 12 (5): 603-607.

Brasil. (2009). Teste de germinação. Regras para análise de sementes. MAPA, Brasília, 399 p.

Coimbra, R. D. A . et al . (2007). Germination test with packgaing the rolls of paper in plastic sacks. Rev. Bras. Sementes, 29 (1): 92-97.

Delouche, J. C.; Baskin, C. C. (1973). Accelerated aging techniques for predicing the relative storability of seed lots. Seed Sci. Technol., $1: 427-452$.

Dutra, A. S.; Vieira, R. D. (2004). Envelhecimento acelerado como teste de vigor para sementes de milho e soja. Cienc. Rural, 34, (3): 715-721.

Khan, M. M. et al. (2003). Effect of Ageing on Viability, Vigour and Chromosomal Damage in Pea (Pisum sativum L.) seeds. Pakistan J. Agri. Sci., 40 (1): 50-54.

Maguire, J. D. (1962). Speed of germination-aid in selection and evaluation for seedling emergence and vigor. Crop Sci., 2 (2): 176-177. 
Marcos-Filho, J. (1999).Teste de envelhecimento acelerado. In: Krzyanowski, F. C.; Vieira, R. D., França-Neto, J. B. (Ed.). Vigor de sementes: conceitos e testes. ABRATES, Londrina, pp.1-24.

Mayer, E.; et al. (2007). Caracterização nutricional de grãos integrais e descascados de cultivares de cevada. Pesq. Agropec. Bras., 42, (11) : 1635-1640.

Mbofung, G. C. Y. et al. (2013). Effects of storage temperature and relative humidity on viability and vigor of treated soybean seeds. Crop Sci., 53 (3): 1086-1095.

Rodrigues, M. B. C. et al. (2006). Pré-hidratação em sementes de soja e eficiência do teste de condutividade elétrica. Rev. Bras. Sementes, 28 (2): 168-181.

Rosa, S. D. V. F. et al. (2000). Eficácia do teste de condutividade elétrica para uso em estudos de danos de secagem em sementes de milho. Rev. Bras. Sementes, 22 (1): 54-63.

Samarah, N. H.; Al - Kofahi, S. (2008). Relationship of Seed Quality Tests to Field Emergence of Artificial Aged Barley Seeds in the Semiarid Mediterranean Region. JJAS, 4 (3): 217 - 230.

Scappa-Neto, A. et al. (2000).Variação do teor de água em sementes de soja e da temperatura e umidade relativa do ar no interior das câmaras no teste de envelhecimento acelerado. Rev. Bras. Sementes, 22 (2): 78-85.

Seal, C. E.; Kranner, I.; Pritchard, H. W. (2008). Quantification of seed oil from species with varying oil content using supercritical fluid extraction. Phytochem. Anal., 19 (6): 493-498.

Shaban, M. (2013). Study on some aspects of seed viability and vigor. IJABBR,1 (12): 16921697.

Sibrargen. (2016). Sistema Brasileiro de Informações em Recursos Genéticos. Brasilia, 2016. Disponível em: https://www.embrapa.br/recursosgeneticosebiotecnologia/pesquisaedesenvolvimento/recursos-geneticos-e-biotecnologia/bases-de-dados/sibrargen >. Acesso em: 07.01.2016.

Silva, V. N. Zambiasi, C. A.; Tillmann, M. A. A.; Menezes, N. L.; Villela, F. A. (2014). Condução do teste de condutividade elétrica utilizando partes de sementes de feijão. Ver. de Ciências Agrárias, 37 (2): 206-213.

Spinola, M. C. M.; Cícero, S. M.; Melo, M. (2000). Alterações bioquímicas e fisiológicas em sementes de milho causadas pelo ao envelhecimento acelerado. Sci. Agric., 57 (2): $263-270$.

Upadhyaya, H. D.; Gowda, C. L. L.; Sastry, D. V. S. S. R. (2008). Plant genetic resources management: collection, characterization, conservation and utilization. J. SAT Agric. Res., $6: 1-16$. 
Vieira, R. D.; Krzyanowski, F. C. Teste de condutividade elétrica. In: Krzyanowski, F. C.;Vieira, R. D.; França-Neto, J. B. (Ed.). Vigor de sementes conceitos e testes. ABRATES, Londrina, pp.1-20.

Vieira, R. D. et al. (2002). Condutividade elétrica e teor de água inicial das sementes de soja. Pesq. Agropec. Bras., 37 (9): 1333-1338. 


\section{CAPÍTULO 2. QUANTIFICAÇÃO DE ÁCIDOS NUCLEICOS ORIUNDOS DE EMBRIÕES DE SOJA EM DIFERENTES NÍVEIS DE DETERIORAÇÃO}

\section{RESUMO}

O objetivo desse trabalho foi comparar e validar três métodos de quantificação de ácidos nucleicos extraídos de sementes de soja em diferentes níveis de envelhecimento. A indução de degradação do DNA foi testada pelos métodos: sonicação e aquecimento a $95^{\circ} \mathrm{C}$ em banho-maria e termociclador. A quantificação foi avaliada em espectrofotômetro, fluorímetro e por comparação da fluorescência sobre luz UV com DNA padrão (gel eletroforese e $\lambda$ em gotas). A indução de deterioração no DNA por sonicação não provocou nenhuma alteração no DNA visualizado em gel. O aquecimento a $95^{\circ} \mathrm{C}$ foi capaz de diminuir a intensidade da banda do DNA genômico. A quantificação do DNA de embrião por espectrometria UV apresentou variação alta quando comprada com as outras metodologias de quantificação, sendo a quantificação em fluorímetro a mais eficiente para esse tipo de material. A quantificação do RNA de embrião foi mais eficiente por espectrometria UV e a variação entre as metodologias foi mais baixa do que as encontradas na quantificação do DNA. As concentrações obtidas por espectrometria e dot foram próximas, o que indica que na falta de um espectrofotômetro, o RNA pode ser quantificado via dot, que é uma metodologia mais barata.

Palavras-chave: espectrofotometria UV, fluorímetro, degradação DNA e RNA.

\subsection{INTRODUÇÃO}

A extração de DNA e RNA é um dos passos cruciais para a análise em biologia molecular, é o ponto de partida para processos de transformação e desenvolvimento de produtos (Tan e Yiap, 2009). No geral, são necessárias amostras de alta qualidade, isto é, com poucas contaminações e íntegros.

Após a extração, a quantidade e a qualidade dos ácidos nucleicos devem ser avaliadas. Existem vários métodos para a quantificação de ácidos nucleicos entre eles a espectrometria UV, a mensuração da fluorescência induzida pela luz UV com a intercalação do brometo intercalado e o ácido nucleico, a espectroscopia de fluorescência e a quantificação em PCR quantitativo. A espectrometria mede a máxima absorbância de ácidos nucleicos, na espectroscopia de fluorescência um corante fluorescente liga-se especificamente ao tipo de 
ácido nucleico. Já na quantificação por PCR quantitativo ocorre uma quantificação relativa de uma sequencia específica de DNA (Pfaffl, 2001; Barbas et al., 2007; Nakayama et al., 2016).

A avaliação de vários processos biológicos, entre eles o envelhecimento de sementes, passa pela degradação de ácidos nucleicos (Waterworth et al., 2016). Nos estudos de envelhecimento de sementes conservadas em longo prazo, a avaliação da degradação tem sido realizada em algumas espécies em que o DNA é degradado seguindo um padrão de morte celular programada, isto é, o DNA é clivado de maneira específica, o que gera um padrão de bandas (DNA laddering) em gel de agarose, corado com brometo (Faria et al., 2005; ElMaarouf-Bouteau et al., 2011).

A degradação e sistema de reparo foram avaliados em sementes de ervilha envelhecidas artificialmente por diferentes períodos e foi observado que quanto maior o período de envelhecimento, maior era a intensidade da fluorescência dos fragmentos e que com o decorrer da germinação essa intensidade diminuía, indicando que houve reparo do DNA durante a embebição (Kranner et al., 2011). Entretanto, a morte celular programada não é observada ou detectada em todas as sementes, o que faz que a degradação seja avaliada de maneira indireta, isto é, pela quantidade de DNA íntegro na amostra. O problema dessa abordagem é que o DNA degradado interfere na quantificação, podendo levar a resultados falsos.

O objetivo desse trabalho foi comparar e validar três métodos de quantificação de ácidos nucleicos extraídos de sementes de soja com diferentes níveis de deterioração.

\subsection{MATERIAIS E MÉTODOS}

\subsubsection{Material}

Foram utilizadas sementes de soja do acesso BRS 7980. Além do DNA do embrião de soja, também foram avaliados DNA extraído da folha, cotilédone e raízes com oito dias após o inicio da germinação.

Como padrão de amostra de DNA limpo, foram utilizadas duas amostras de DNA de sangue animal do Laboratório de Genética Animal e DNA de folha de amendoim do Laboratório de Genética Vegetal. Ambos os laboratórios estão localizados na Embrapa Recursos Genéticos e Biotecnologia e possuem rotina de extração de DNA para análises moleculares já estabelecidas para esses dois tipos de tecidos. 
Para o RNA, também foi utilizado o embrião de soja com sete diferentes períodos de envelhecimento acelerado, para se avaliar se o envelhecimento causa perda na quantificação do RNA.

\subsubsection{Métodos}

\subsubsection{Extração do DNA}

O DNA dos diferentes tecidos de soja foi extraído pelo método CTAB 2x (Ferreira e Grattapaglia, 1996). As amostras animais utilizadas como padrão de DNA limpo foram extraídas de acordo com Miller (1988). E a amostra vegetal utilizada como padrão de DNA limpo foi extraída pelo método CTAB, mas modificado (3x e adição de etapa com sorbitol antes da maceração).

\subsubsection{Extração do RNA}

A extração foi realizada de acordo com método de Wang e Wodking (1994) com três repetições biológicas para cada tempo. Para o RNA foi utilizado apenas o embrião de soja envelhecida artificialmente a $42^{\circ}$, a $100 \%$ de umidade relativa, por sete tempos diferentes $(0$, $6,12,24,48,72$ e 96 horas).

\subsubsection{Obtenção de controle positivo de degradação de DNA}

Para a obtenção de DNA degradado para ser utilizado como controle positivo de degradação, testaram-se três métodos para indução de quebra do DNA:

- Aquecimento a $95^{\circ} \mathrm{C}$ em banho-maria por 0', 30', 2', 5' e 10';

- Aquecimento a $95^{\circ} \mathrm{C}$ em termociclador por 0, 7’, 15’, 30” 1', 2', 3', 4', 5', 10 ; e

- sonicação em lavadora ultrassônica USC2800 (Unique) por 0', 10', 20', 30', 40', 50' e 60'.

O DNA foi dividido em três alíquotas de mesma concentração para utilização em cada um dos métodos supracitados de indução de quebra.

\subsubsection{Quantificação de ácidos nucleicos}

As quantificações do DNA e RNA foram realizadas utilizando-se fluorimetria (Qubit®), por comparações com padrões de concentrações de DNA conhecidas em gota (dot) e em gel de agarose (apenas para DNA), por espectrofotometria (NanoDrop® ND - 1000 UVVis). 
A quantificação via dot foi realizada com $3 \mu \mathrm{L}$ de DNA padrão lambda (Roche) ou do DNA estudo, mais $2 \mu \mathrm{L}$ de brometo de etídio $(20 \mu \mathrm{g} / \mathrm{mL})$. As misturas de DNA ou RNA mais brometo foram depositadas em lâmina microscópica e imediatamente fotografadas em transiluminador UV. Posteriormente, a comparação da intensidade dos padrões e amostras foi realizada e a concentração do DNA ou RNA foram estimadas.

A quantificação por Qubit foi realizada de acordo com recomendações do fabricante para cada tipo de ácido nucleico.

\subsection{RESULTADOS E DISCUSSÃO}

No geral, os trabalhos envolvendo ácidos nucleicos têm objetivos que requerem DNA puro e de alto peso molecular, isto é, pouco degradado. Poucos são os trabalhos que focam na avaliação da degradação do ácido nucleico e na quantificação de DNA íntegro e degradado (Deagle et al., 2006; Shokere et al., 2009; Kranner et al., 2011) . Em função disso, foram testados dois métodos de degradação e três métodos de quantificação.

\subsubsection{Obtenção de controle positivo de degradação de DNA}

Os resultados obtidos utilizando-se os diferentes métodos indutores de degradação de DNA (aquecimento a $95^{\circ} \mathrm{C}$ em banho-maria e em termociclador e sonicação) são apresentados na Figura 2.1.

$\mathrm{O}$ aquecimento a $95^{\circ} \mathrm{C}$, tanto em banho-maria como em termociclador, provocou degradação do DNA (Figura 2.1a). A redução na quantidade de DNA íntegro foi menor quando o aquecimento foi em termociclador, uma vez que esse não fez desaparecer totalmente a banda do DNA genômico em nenhum dos tempos, como observado no aquecimento realizado em banho-maria. Mas, diferenças entre controle e teste foram observadas a partir de 7 segundos de tratamento (Figura 2.1a). Já para o aquecimento em banho-maria com 2,5 min de exposição houve diminuição da intensidade da banda e com 5 min, o desaparecimento total da banda de DNA genômico (Figura 2.1b). Dentre os métodos avaliados, o aquecimento a $95^{\circ} \mathrm{C}$ em banho-maria mostrou ser o mais eficiente, pois apresentou diminuição da intensidade da banda como também o desaparecimento da mesma, sendo mais interessante para avaliação da quantificação do DNA degradado e íntegro.

A sonicação foi avaliada utilizando-se sete tempos de exposição (de 0 a 60 min). Entretanto, como pode ser observado na Figura 2.1c, nenhuma alteração na qualidade do DNA foi observada em gel de agarose. Vargas et al. (2012), também não observaram 
alteração na qualidade do DNA de três acessos de dendê (Elaeis guineensis Jacq.), após períodos de até 40 min de sonicação.

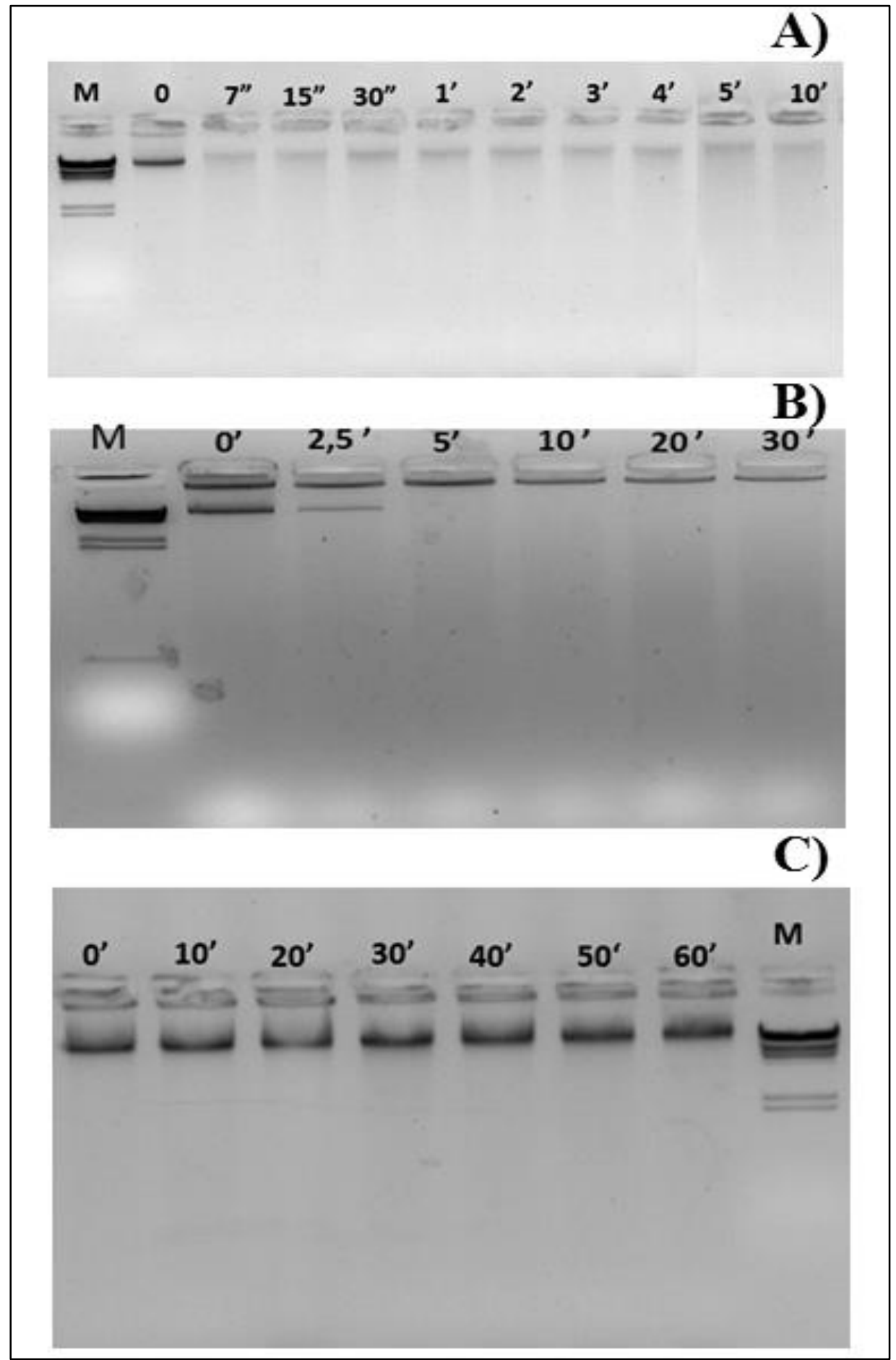

Figura 2.1 Amostras de DNA da soja que passaram por diferentes métodos para indução de fragmentação: a) $95^{\circ} \mathrm{C}$ em termociclador de 0 min a $10 \mathrm{~min}$, b) $95^{\circ} \mathrm{C}$ em banho-maria de 0 a 30 min e c) sonicação de 0 a 60 min. Linha $M=$ marcador lambda DNA Hind III. As amostras estavam com a mesma concentração de DNA antes da indução da degradação. 
A quantificação do DNA deteriorado por aquecimento apresentou grande variação na concentração entre o método de espectrometria e o de fluorimetria e o dot (Figura 2.2).

O efeito da degradação foi melhor visualizado por fluorímetro, no qual houve diminuição da concentração de DNA com a degradação. A espectrometria não demonstrou variação acentuada entre as amostras, isso porque de acordo com Sedlackova et al. (2013) a degradação do DNA não interfere na quantificação por espectrofotômetro, ele é hábil para quantificar tanto DNA intacto quanto DNA degradado.

A obtenção de um controle positivo de degradação foi essencial para a avaliação dos métodos de quantificação.

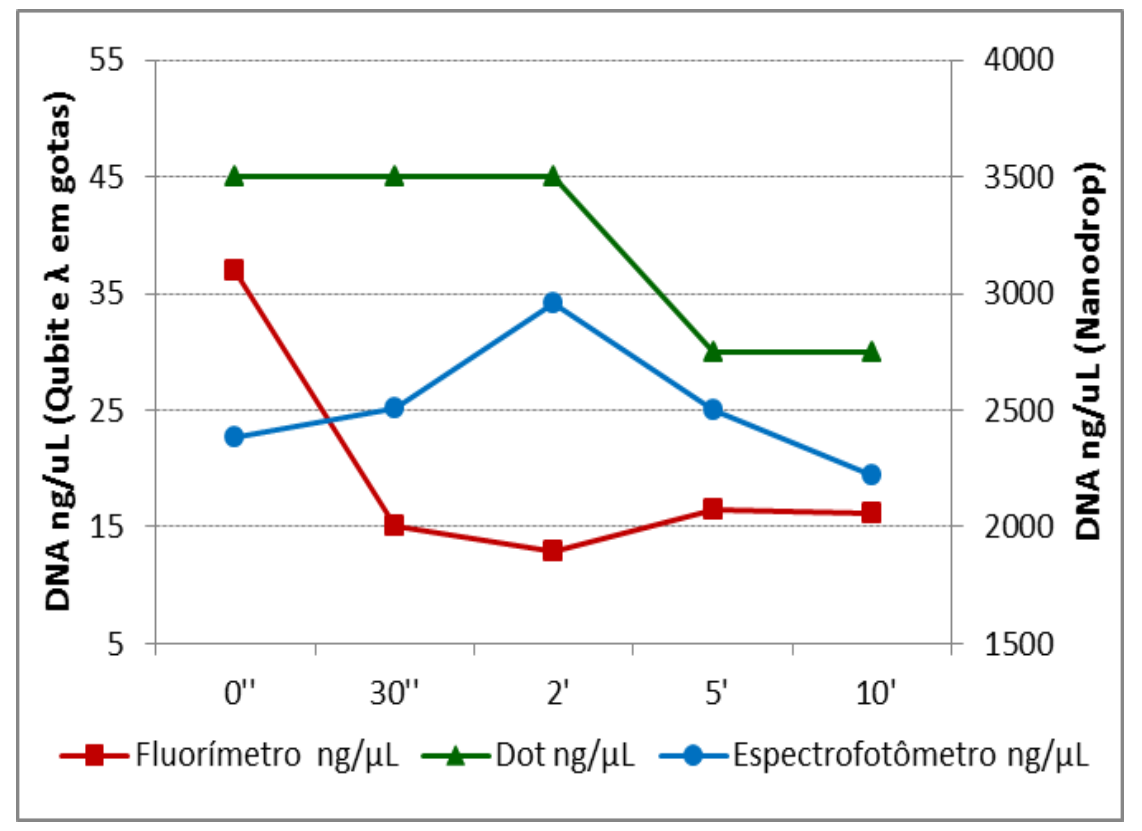

Figura 2.2. Quantificação dos DNAs oriundos de processo de degradação a $95^{\circ} \mathrm{C}$ em cinco diferentes tempos, calculado por diferentes metodologias de quantificação. Observa-se que com o aumento do tempo da indução da degradação do DNA há que da na concentração do DNA tanto para a quantificação por fluorimetria com para a quantificação por Dot, porém para a quantificação por espectrometria não é observada grande variação da concentração do DNA em função da indução de degradação.

\subsubsection{Quantificação de ácidos nucleicos}

$\underline{\text { DNA }}$

A quantificação de DNA permite também estimar a pureza da amostra calculando as razões 260/280 (contaminação por proteínas) e 260/230 (contaminação por polissacarídeos e 
ou solventes orgânicos). Geralmente razões 1,8 são aceitas como bom grau de pureza para DNA e 2,0 para RNA (Termoscientific, 2010a; b).

De acordo com os dados obtidos por espectrofotômetro todos os DNAs avaliados apresentaram boa pureza em relação à contaminação com proteínas. Já para a contaminação por solventes orgânicos e/ou polissacarídeos apenas o DNA de embrião de soja estava puro (Tabela 2.1). Como pode ser observado na Tabela 2.1, a concentração de DNA das amostras vegetais variou muito, o que indica que o espectrofotômetro não quantificou apenas DNA e que as amostras vegetais não estavam puras.

Tabela 2.1 Teste comparativo da quantificação de DNA de diferentes organismos por diferentes metodologias (em $\mathrm{ng} / \mu \mathrm{L})$.

\begin{tabular}{ccccccc}
\hline \multirow{2}{*}{ Amostra } & \multicolumn{6}{c}{ Metodologias } \\
\cline { 2 - 6 } & Espectrofotômetro & $260 / 280$ & $260 / 230$ & Fluorímetro & Dot & Gel \\
\hline Animal 1 & 61,9 & 1,8 & 1,2 & 60,8 & 75 & 80 \\
Animal 2 & 76,7 & 1,8 & 1,2 & 62,2 & 80 & 90 \\
Folha Arachis & 454,4 & 2,1 & 1,8 & 54,4 & 125 & 50 \\
Embrião Soja & 3931,1 & 1,9 & 2,0 & 57,0 & 100 & 65 \\
Folha Soja & 3466,9 & 1,9 & 1,7 & 230,0 & 150 & 400 \\
Raiz Soja & 1310,1 & 1,8 & 1,3 & 59,8 & 70 & 45 \\
Cotilédone Soja & 2662,6 & 1,7 & 1,0 & 156 & 100 & 300 \\
\hline
\end{tabular}

De modo geral, as quantificações do DNA animal apresentaram as menores variações entre as metodologias, o que mostra que este DNA estava puro (Figura 2.3). Esse resultado pode ser devido ao fato de que a matriz de onde esse DNA foi extraído, tecido sanguíneo, tem menos impurezas do que qualquer tecido vegetal.

O DNA da folha de amendoim, mesmo passando por extração pelo método CTAB modificado (adição de etapa com sorbitol antes da maceração e CTAB 3x), apresentou boa pureza de acordo com o espectrofotômetro, mas a concentração também variou bastante entre as metodologias (Tabela 2.1 e Figura 2.3).

Dentre todos os materiais avaliados, a maior variação entre as concentrações foi encontrada para os tecidos de soja, principalmente quando comparadas com as obtidas por espectrometria. As concentrações obtidas para essa metodologia foram muito altas, indicando que não foi quantificado apenas DNA (Figura 2.3). 


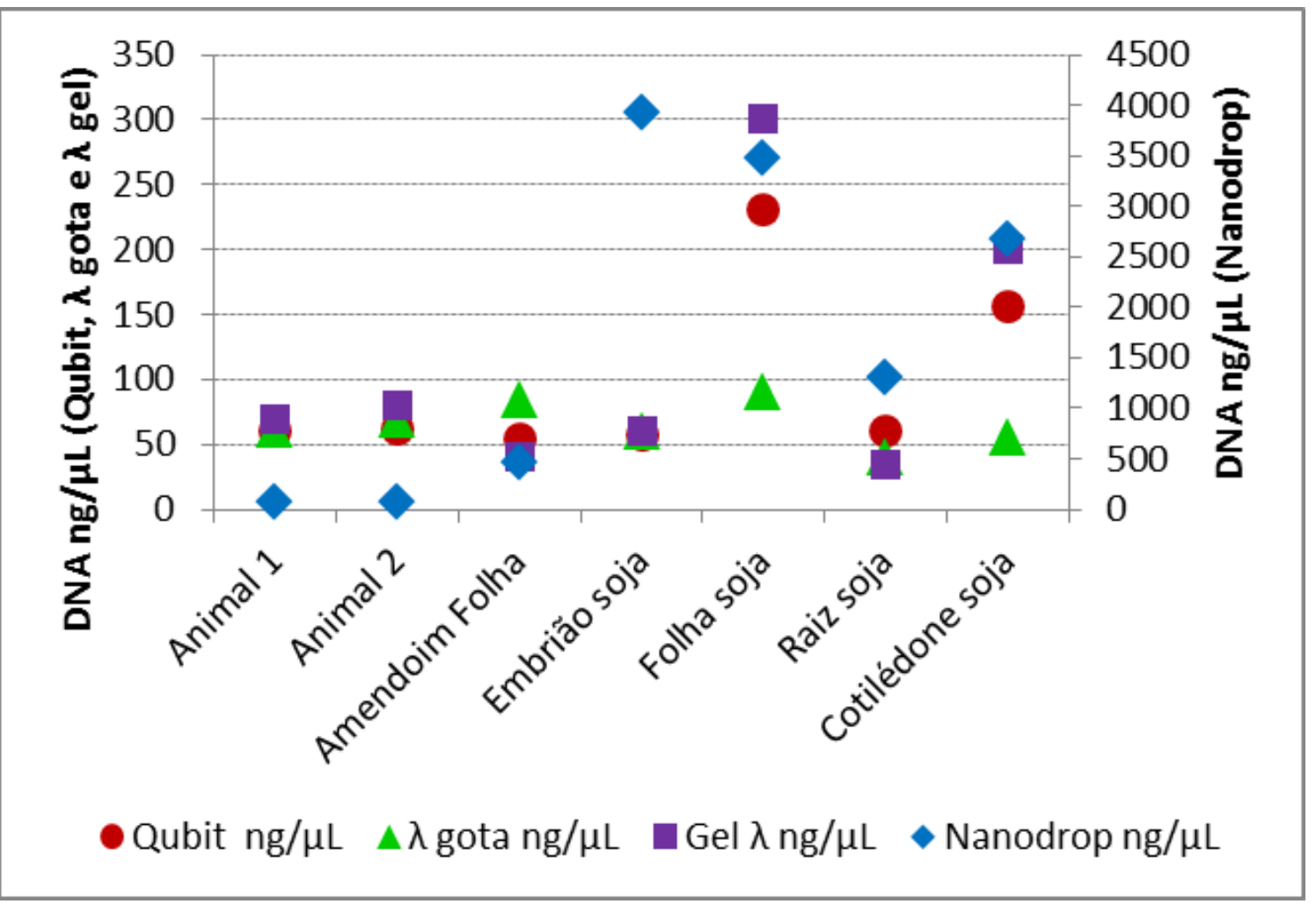

Figura 2.3. Variação na concentração do DNA entre as diferentes metodologias de quantificação. No eixo y principal se encontram as concentrações obtidas por fluorimetria, dot e gel. No eixo y secundário as concentrações obtidas por espectrometria, a qual apresentou grande diferença nas concentrações comparando com as demais metodologias avaliadas.

A maior variação nas concentrações de DNA das amostras vegetais entre os diferentes métodos de quantificação pode ser devido ao fato de que a extração de ácidos nucleicos de plantas é dificultada pela presença de metabólitos primários - como os polissacarídeos e lipídeos - e secundários, como os compostos fenólicos (Rathnayake et al., 2014; Chabi Sika et al., 2015).

No caso do DNA de sementes, a metodologia passou por algumas otimizações (dados não mostrados). A melhor foi a adição de proteinase $\mathrm{K}$ e mais lavagens com clorofórmio: álcool isoamílico (25:1), que deixaram o pellet mais limpo. Porém, com esse DNA não foi possível a amplificação via PCR. Então, optou-se pela extração do DNA apenas do embrião e o pellet ficou visivelmente mais limpo. Então, foi possível a amplificação via PCR, mesmo com a quantificação por espectrofotômetro mostrar uma variação bastante alta.

As quantificações por dot e gel (Figura 2.4) apresentaram menos variação do que a quantificação por espectrofotômetro. Em laboratórios que não possuam métodos de quantificação mais sofisticados como espectrofotometria e/ou fluorímetria, essas 
metodologias podem ser de grande valia, principalmente o dot, que por não precisar de corrida de eletroforese é mais rápida.

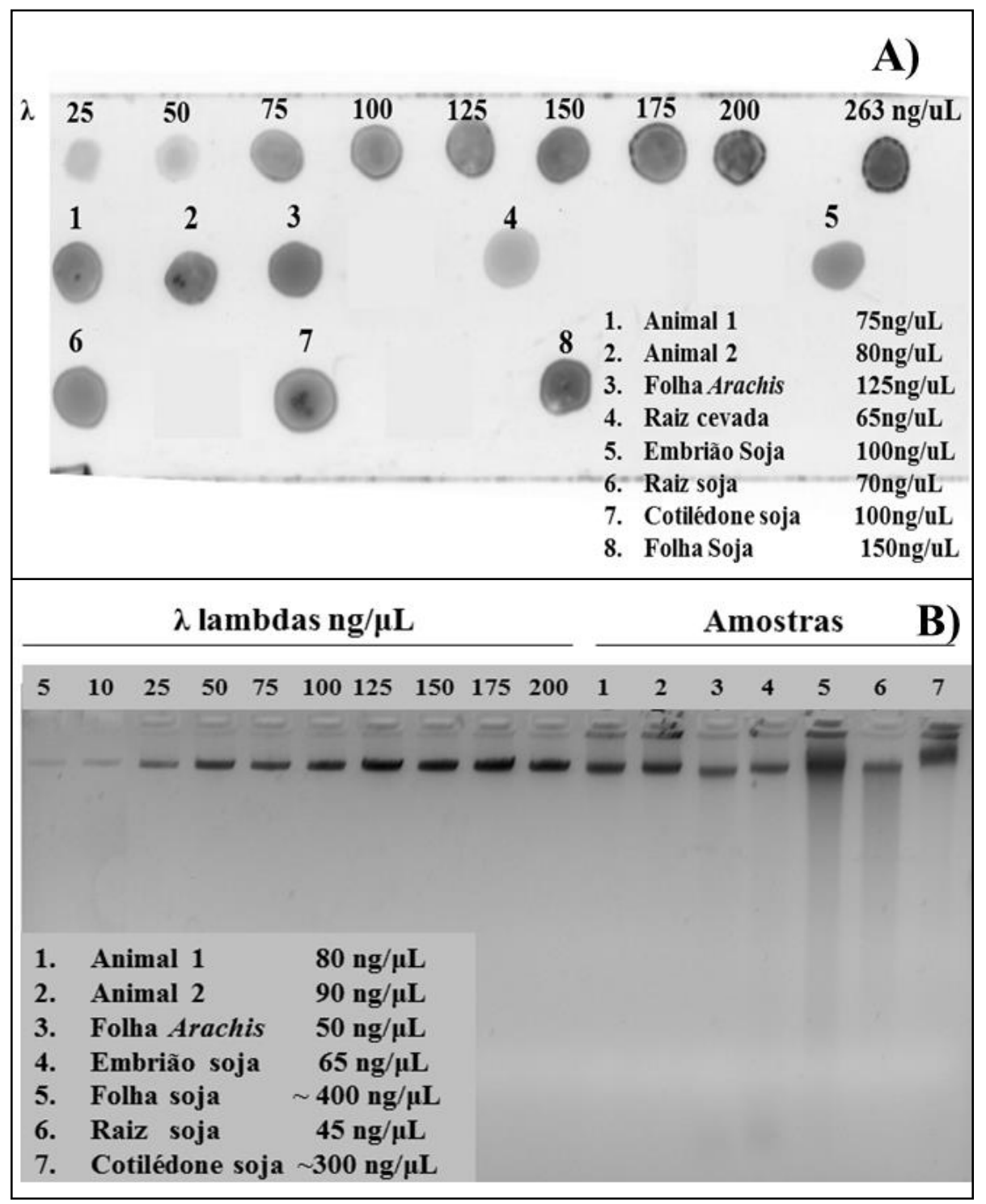

Figura 2.4 Quantificações por comparação com DNA padrão com concentração conhecida: a) Quantificação por dot em lâmina e b) Quantificação por gel de agarose.

De acordo com Barbas et al. (2007), se uma amostra de DNA está pura um dos caminhos eficientes para quantificá-la é a espectrometria, porém se a amostra não está pura é recomendável a quantificação desta por gel. Porém, para esse estudo a quantificação por gel não foi eficiente, pois com a corrida de eletroforese perde-se a capacidade do método de quantificar tanto DNA íntegro como degradado, sendo possível apenas a quantificação de DNA íntegro. 
Dentre todas as metodologias de quantificação de DNA testadas, a mais consistente foi a quantificação por fluorímetro, pois apresentou pouca variação na concentração comparada com as demais metodologias e foi mais objetiva. Assim, optou-se por adotar a quantificação de DNA por fluorímetro para as análises moleculares deste trabalho. E quando necessário, o uso da quantificação por dot como auxiliares, já que há relatos de que a quantificação por fluorimetria não é eficiente para a quantificação de DNA degradado (Shokere et al., 2009; Sedlackova et al. 2013). A quantificação por espectrofotômetro por ser rápida continuou sendo realizada, para se ter uma ideia melhor da qualidade do DNA, através dos espectros e das razões 260/280 e 260/230 obtidas nessa metodologia.

\section{$\underline{\mathrm{RNA}}$}

A extração de RNA resultou em um material mais puro do que as amostras de DNA, por isso a variação na quantificação entre as diferentes metodologias foi mais baixa. As amostras apresentaram boa pureza em relação à contaminação com proteínas, com razões 260/280 de 2,0 a 2,2 (Tabela 2.2). Para a contaminação por solventes orgânicos e/ou polissacarídeos, o RNA apresentou maior pureza comparado com o DNA de algumas amostras, como cotilédone e raiz, com razões 260/230 de 1,5 a 2,1 (Tabela 2.2).

No geral, as variações na quantificação do RNA, entre as diferentes metodologias, foram bem menores quando comparadas com as variações encontradas na quantificação do DNA (Tabela 2.2). As concentrações obtidas por espectrometria e dot foram próximas, o que indica que na falta de um espectrofotômetro o RNA pode ser quantificado via dot, que é uma metodologia mais barata.

Kranner et al. 2011, observaram redução na concentração de RNA em amostras de ervilha (Pisum sativum L.) conforme o aumento do tempo envelhecimento, chegando a redução de mais de 50\% na concentração de RNA para sementes com $44 \%$ de germinação em relação ao controle ( $98 \%$ de germinação). Entretanto, neste estudo com RNA extraído de sementes de soja não foi encontrado diferenças entre as concentrações de RNA para os diferentes tempos de envelhecimento (Tabela 2.2). É provável que houve degradação do RNA durante a extração, por isso não houve diferenças na concentração. 
Tabela 2.2. Teste comparativo da quantificação de RNA por diferentes metodologias em grupos de amostras com diferentes tempos de envelhecimento.

\begin{tabular}{cccccc}
\hline \multirow{2}{*}{ Amostra } & \multicolumn{5}{c}{ Metodologias } \\
\cline { 2 - 6 } & $\begin{array}{c}\text { Espectrometria } \\
\mu \mathrm{g} / \mu \mathrm{L}\end{array}$ & $260 / 280$ & $260 / 230$ & $\begin{array}{c}\text { Fluorímetro } \\
\mu \mathrm{g} / \mu \mathrm{L}\end{array}$ & dot $\mu \mathrm{g} / \mu \mathrm{L}$ \\
\hline $0 \mathrm{~h}$ & $1,15^{\mathrm{a}}$ & $2,0-2,1$ & 1,5 & $0,82^{\mathrm{a}}$ & $1,20^{\mathrm{a}}$ \\
$6 \mathrm{~h}$ & $1,16^{\mathrm{a}}$ & 2,1 & $1,8-1,9$ & $1,13^{\mathrm{a}}$ & $1,10^{\mathrm{a}}$ \\
$12 \mathrm{~h}$ & $1,30^{\mathrm{a}}$ & 2,1 & $1,6-1,9$ & $0,92^{\mathrm{a}}$ & $1,71^{\mathrm{a}}$ \\
$24 \mathrm{~h}$ & $1,08^{\mathrm{a}}$ & 2,1 & $1,8-2,0$ & $0,76^{\mathrm{a}}$ & $1,33^{\mathrm{a}}$ \\
$48 \mathrm{~h}$ & $1,05^{\mathrm{a}}$ & 2,1 & $2,0-2,1$ & $1,09^{\mathrm{a}}$ & $1,33^{\mathrm{a}}$ \\
$72 \mathrm{~h}$ & $1,15^{\mathrm{a}}$ & $2,0-2,2$ & $1,8-2,1$ & $1,04^{\mathrm{a}}$ & $1,12^{\mathrm{a}}$ \\
$96 \mathrm{~h}$ & $0,91^{\mathrm{a}}$ & 2,0 & $1,8-1,9$ & $1,41^{\mathrm{a}}$ & $1,44^{\mathrm{a}}$ \\
\hline
\end{tabular}

Letras iguais em uma mesma coluna não diferem de acordo com o teste de Kruskal-wallis $(p \leq 0,05)$.

\section{4 CONCLUSÃO}

O método de degradação de DNA por aquecimento a $95^{\circ} \mathrm{C}$ em banho maria foi mais eficiente para obtenção de um controle positivo de degradação, pois apresentou redução da intensidade da fluorescência e, em seguida, o desaparecimento total da banda do DNA.

A quantificação por fluorimetria e por dot foram mais consistentes entre todas as metodologias avaliadas, sendo que a por fluorimetria foi mais objetiva. Mas, em laboratórios que não tenham disponíveis métodos de quantificação mais objetivos a quantificação por dot pode ser uma boa metodologia substitutiva.

A quantificação de RNA de soja por espectrometria foi mais eficiente, pois entre as três metodologia foi a que menos divergiu das demais, além de mostrar a pureza da amostra e ser mais prática. Assim, neste trabalho foi adotada a quantificação de RNA por espectrofotômetro.

\section{5 REFERÊNCIAS}

Barbas, C. F. Burton, D. R.; Scott, J. K.; Silverman, G. J. (2007). Quantitation of DNA and RNA. Cold Spring Harb. Protoc., 11: 1- 6.

Deagle, B. E.; Eveson, P.; Jarman, S. N. (2006). Quantification of damage in DNA recovered from highly degraded samples - a case study on DNA in faeces. Front Zool., 3 (11): $1-10$.

El-Maarouf-Bouteau, H. Mazuy, C; Corbineau, F e Bailly, C. (2011). DNA alteration and programmed cell death during ageing of sunflower seed. J. Exp. Bot., 62 (14): $5003-5011$. 
Faria, J. M. R.; Buitink, J.; van Lammeren, A. A. M.; Hilhorst, H. W. M. (2005). Changes in DNA and microtubules during loss and re-establishment of desiccation tolerance in germinating Medicago truncatula seeds. J. Exp. Bot., 56 (418): p. 2119-2130.

Ferreira, E.; Grattapaglia, D. (1996). Introdução ao uso de marcadores moleculares em análise genética. Embrapa, Brasília, $3^{\mathrm{a}}$ ed, 220p.

Kranner I; Chen H; Pritchard H; Pearce S; Birtić S. (2011). Inter-nucleosomal DNA fragmentation and loss of RNA integrity during seed ageing. Plant Growth Regul., 63 (1): 63-72.

Nakayama, Y.; Yamaguchi, H.; Einaga, N.; Esumi, M. (2016). Pitfalls of DNA Quantification Using DNA-Binding Fluorescent Dyes and Suggested Solutions. PLoS ONE, 11(3): e0150528.

Pfaffl, M. W. (2001). A new mathematical model for relative quantification in real-time RTPCR. Nucleic Acids Res., 29 (9): e45-e45.

Sedlackova, T.; Repiska, G.; Celec, P.; Szemes, T.; Minarik, G. (2013). Fragmentation of DNA affects the accuracy of the DNA quantitation by the commonly used methods. Biol. Proced. Online, 15 (5): 1- 8.

Shokere, L. A.; Holden, M. J.; Jenkins, G. R. Comparison of fluorometric and spectrophotometric DNA quantification for real-time quantitative PCR of degraded DNA. Food Control, 20: 391 - 401.

Tan, S. C.; Yiap, B. C. (2009). DNA, RNA, and Protein Extraction: The Past and The Present. J Biomed Biotechnol, 2009 (574398): 1 - 10.

Termoscientific. (2010a). Detection and Avoidance of Polysaccharides in Plant Nucleic Acid Extractions. Disponível em: < http://www.nanodrop.com/Library/T111Detection-and-Avoidance-of-Polysaccharides-in-Plant-Nucleic-AcidExtractions.pdf >. Acesso em: 08/08/2016.

(2010b). NanoDrop 1000 Spectrophotometer V3.8 User's Manual. Disponível em: < http://www.nanodrop.com/Library/nd-1000-v3.8-users-manual8\%205x11.pdf > . Acesso em: 08/08/2016.

Vargas, L. H. G. et al. (2012). Avaliação da fragmentação do DNA genômico de Elaeis guineensis Jacq. e Elaeis oleífera (Kunth) Cortés por meio de ondas sonoras de alta frequência e autoclavagem. IV Workshop Agroenergia, Riberão Preto - SP, pp 3.

Wang, C. S.; Vodking, L. (1994). Extraction of RNA from tissues containing high levels of procyanidins that bind RNA. Plant Mol. Bio. Rep., 12 (2): 132-145.

Waterworth, W. M. Footitt, S.; Bray, C. M.; Finch-Savage, W. E.; West, C. E. (2016). DNA damage checkpoint kinase ATM regulates germination and maintains genome stability in seeds. PNAS, 113 (34): 9647-9652. 


\section{CAPÍTULO 3 - AVALIAÇÃo DA INTEGRIDADE DE ÁCIDOS NUCLEICOS EM SEMENTES DE SOJA E CEVADA ENVELHECIDAS ARTIFICIALMENTE}

\section{RESUMO}

Neste trabalho foi avaliada a integridade de ácidos nucleicos por meio de diferentes técnicas com o intuito de se obter informações que contribuam para o melhor entendimento do processo de manutenção da integridade e na identificação de técnicas que possam ser utilizadas para avaliação de ácidos nucleicos em bancos de germoplasma. O sistema de reparo e a integridade do DNA e a integridade do RNA, pela visualização das bandas 18 e 28s, foram avaliados em gel de agarose corado com brometo de etídio. RAPD foi utilizado para se avaliar também o sistema de reparo do DNA e a possível introdução de variabilidade genética devido ao envelhecimento. O qPCR foi utilizado para identificação de deterioração do DNA. As avaliações das integridades do DNA e RNA em gel de agarose tiveram pouca repetibilidade, não permitiram a distinção entre os lotes ou necessitaram de uma grande quantidade de material (1-3 $\mu \mathrm{g})$. Não foi detectadas diferenças na integridade do RNAs de sementes envelhecidas, exceto para os tempos 48 h e 96 h de envelhecimento. Os resultados do RAPD mostraram diferenças na integridade e na capacidade de reparo do DNA entre os diferentes lotes de sementes. Foram testados fragmentos de três tamanhos diferentes para avaliar o potencial do qPCR na a diferenciação dos lotes das amostras. Os fragmentos de maior comprimento diferenciaram melhor os lotes de sementes. Dentre todas as metodologias moleculares avaliadas, o qPCR foi a melhor para avaliar a integridade das sementes durante o envelhecimento, pois, diferenciou melhor as amostras necessitando de quantidades baixas de DNA (aproximadamente $6 \mathrm{ng}$ ).

Palavras-chave: DNA, qPCR, RAPD, reparo do DNA, RNA.

\subsection{INTRODUÇÃO}

Um dos processos que ocorre durante o envelhecimento das sementes é o dano às estruturas dos ácidos nucleicos (Jyoti e Malik, 2013). A partir desse princípio, o uso de técnicas moleculares, em complementação ao teste de germinação, poderia auxiliar na manutenção de bancos de germoplasma detectando estágios de deterioração em sementes antes da perda total da viabilidade destas.

Um método de baixo custo para a avaliação da integridade de sistema de reparo de ácidos nucleicos durante o envelhecimento em sementes foi utilizado por Kranner et al. 
(2011). Esses autores avaliaram a integridade de ácidos nucleicos de sementes de ervilha (Pisum sativum L.) envelhecidas artificialmente por meio da técnica de gel de agarose e observaram que quanto mais envelhecida a amostra maior a intensidade da fluorescência dos fragmentos de DNA (DNA laddering) no gel. Esses autores observaram também que durante a embebição, a intensidade dos fragmentos diminuía, mostrando que houve reparo do DNA e que a intensidade de fluorescência das bandas $28 \mathrm{~s}$ e $18 \mathrm{~s}$ do rRNA diminuíram com o aumento do tempo de envelhecimento.

A avaliação de ácidos nucleicos de sementes em gel de agarose corados com brometo de etídio, apesar de barata, é limitada a algumas espécies, pois demandam quantidades altas de DNA (entre 5 a $10 \mu \mathrm{g}$ ) e RNA (1 a $2 \mu \mathrm{g}$ ) (El-Maarouf-Bouteau et al., 2011; Kranner et al., 2011). A limitação ocorre também porque algumas espécies não se observa o padrão de DNA laddering, a avaliação da integridade do DNA fica comprometida, pois as bandas resultantes da degradação não são visíveis no gel. Dessa maneira, para algumas espécies é necessário o desenvolvimento de metodologias que permitam análises de ácidos nucleicos utilizando-se baixas quantidades e quando não há formação de bandas. As técnicas baseadas em reação em cadeia da polimerase (PCR - Polymerase Chain Reaction) preenchem os requisitos expostos.

O RAPD é uma técnica que utiliza primers curtos (10 nucleotídeos) para amplificação de regiões aleatórias nos genomas das espécies (Bardakci, 2001), tem baixo custo e é aplicável potencialmente a qualquer espécie (Faleiro, 2007). Apesar de seus problemas de reprodutibilidade, quando realizada utilizando-se repetições biológicas a técnica pode ser muito informativa, por exemplo em estudos de variabilidade genética, diversidade genética, na determinação do limite entre espécies filogeneticamente muito próximas e na identificação de espécies (Borges et al., 2000; Araujo et al., 2003; Lupchinski Jr et al., 2006; Pavan e Monteiro, 2014).

A técnica de qPCR reúne todos os atributos acima, isto é, demanda quantidades pequenas (1 - 6ng de DNA) de material, usa primers específicos e permite a quantificação. Dentro das primícias da técnica de qPCR, o threshold é um limite arbitrário calculado pelo próprio aparelho com base na variabilidade da linha de base e o CT (cycle threshold) é o número de ciclos de PCR que a fluorescência é maior do que o nível de detecção mínimo (threshold) (Arya et al., 2005). Murray et al. (2009) demonstraram a utilidade dessa técnica na quantificação e na avaliação da degradação de DNA de soja extraído de produtos industrializados, utilizando a variação no CT detectados por fragmentos de tamanhos diferentes $(86,193,491$ e 1086pb) de um mesmo gene de sojas. 
O objetivo desse trabalho foi avaliar a integridade de ácidos nucleicos por meio de diferentes técnicas, com o intuito de fornecer informações que contribuam para o melhor entendimento desse processo e identificar técnicas que possam ser utilizadas em bancos de germoplasma.

\subsection{MATERIAL E MÉTODOS}

\subsubsection{Material}

As sementes de cevada e soja utilizadas neste estudo foram as mesmas utilizadas no Capítulo 1 e passaram por tratamento de envelhecimento acelerado, conforme descrito no referido capítulo.

\subsubsection{Métodos}

\subsubsection{Experimento de embebição}

Para avaliar o sistema de reparo do DNA das sementes ao longo da germinação, foi realizado um experimento de embebição com as sementes já envelhecidas (Capítulo 1).

Vinte sementes de cada espécie e de cada tratamento de envelhecimento foram colocadas em papel germitest umedecido com água destilada na proporção de 2,5 x a massa do papel seco. O papel foi enrolado e colocado em câmara BOD a $25^{\circ} \mathrm{C}$ por quatro diferentes tempos: 0 hora (controle embebição), 7 horas, 14 horas e 21 horas de germinação.

Após o tempo de embebição as sementes foram congeladas a $-80^{\circ} \mathrm{C}$ até o momento da extração do DNA.

\subsubsection{Extração de ácidos nucleicos}

\section{$\underline{\text { DNA }}$}

O DNA foi extraído conforme metodologia descrita por Ferreira e Grattapaglia (1996) utilizando-se sementes inteiras de cevada e embriões de soja.

Cinco embriões de soja ou cinco sementes de cevada foram macerados em almofariz com nitrogênio líquido até a obtenção de um pó fino, o qual foi colocado em tubo de $2 \mathrm{~mL}$, que já continha $1000 \mu \mathrm{L}$ de tampão CTAB pré-aquecido, por 5 minutos, a $60^{\circ} \mathrm{C}(2,0 \% \mathrm{CTAB}$, 1,4 M NaCl, 20 mM EDTA, 100 mM Tris-HCl pH 8.0, 1,0\% PVP, 0,2\% $\beta$-mercaptoetanol).

Em seguida, os tubos foram incubados a $65^{\circ} \mathrm{C}$ por $30 \mathrm{~min}$, sendo invertidos a cada 5 min. Após a incubação, as amostras foram resfriadas a temperatura ambiente por 15 min e então foram adicionados $650 \mu \mathrm{L}$ de CIA - Clorofórmio: álcool isoamílico (24 : 1). Os tubos foram invertidos vigorosamente até a mistura total das fases e sem seguida, centrifugados por 5 min a $12000 \mathrm{rpm}$. 
Após a centrifugação, o sobrenadante foi transferido para um novo tubo de $1,5 \mathrm{~mL}$ e adicionado 1/3 de álcool isopropanol. Os tubos foram invertidos cuidadosamente e centrifugados por 5 min a $12000 \mathrm{rpm}$. O sobrenadante foi descartado e o pellet lavado com $500 \mu \mathrm{L}$ de álcool etílico $70 \%$, por 5 min por duas vezes, com $500 \mu \mathrm{L}$ álcool etílico absoluto, por 2 min e secos à temperatura ambiente.

Os pellets foram ressuspendidos em $40 \mu \mathrm{L}$ (cevada) ou $100 \mu \mathrm{L}$ (soja) de TE (10 mM Tris-HCl pH 8,0, 1 mM EDTA) contendo RNAse, a $1 \mu \mathrm{g} / \mu \mathrm{L}$.

As extrações de DNA foram realizadas com três repetições. O DNA da soja BRS Flora e Cevada foram quantificados por espectrometria de absorbância (NanoDrop). O DNA da soja BRS 7980 foi quantificado por fluorímetro Qubit®, de acordo com as recomendações do fabricante e, quando necessário, foi utilizado como método auxiliar a quantificação por lâmbidas em gotas.

Os DNAs foram analisados utilizando-se eletroforese em gel de agarose 1,5\%, em tampão TBE $1 \mathrm{X}$ a $5 \mathrm{~V} / \mathrm{cm}$, por $60 \mathrm{~min}$, que foi corado com $0,2 \mu \mathrm{g} / \mathrm{mL}$ de brometo de etídio. Foram colocados no gel de agarose de 1 a $3 \mu \mathrm{g}$ de DNA para a corrida de eletroforese.

Os géis foram visualizados utilizando-se transiluminador de UV BioAgency® e a intensidade dos fragmentos quantificada por análise de imagem, utilizando-se o programa ImageJ (http://imagej.nih.gov/ij/).

$\underline{\text { RNA }}$

Foram testadas seis metodologias para a extração de RNA de sementes:

1. Chang et al., 1993;

2. Wang e Vodking, 1994;

3. Wang et al., 2012;

4. Zarei et al., 2012;

5. Dang e Chen, 2013; e

6. Mornkham et al., 2013.

As extrações foram realizadas com quatro repetições, compostas de 20 embriões para soja e 20 sementes de cevada, totalizando aproximadamente $200 \mathrm{mg}$ para cada repetição. Entre as seis metodologias testadas, a de maior rendimento foi a de Wang e Vodking (1994), assim esta foi utilizada para a extração de RNAs das amostras testes.

As sementes foram maceradas em almofariz com nitrogênio líquido até a obtenção de um pó, ao qual foram adicionados $900 \mu \mathrm{L}$ de tampão de extração (100 mM Tris pH 9.0, 20 mM EDTA, 4\% laurilsarcosina, $200 \mathrm{mM} \mathrm{NaCl}, 2 \% \beta$-mercaptoetanol) e igual volume de 
clorofórmio: álcool isoamílico: fenol (24:1:25), em tubo de $2 \mathrm{~mL}$. A solução foi agitada por 2 min em vortex e centrifugada a $4^{\circ} \mathrm{C}$, por $10 \mathrm{~min}$ a $13000 \mathrm{rpm}$. O sobrenadante foi transferido para novo tubo e a este foi adicionado igual volume de clorofórmio:fenol (1:1). O tubo foi agitado e centrifugado novamente a $4^{\circ} \mathrm{C}$, por $10 \mathrm{~min}$ e $13000 \mathrm{rpm}$.

O sobrenadante foi transferido para um novo tubo de $1,5 \mathrm{~mL}$ e, então, o RNA foi precipitado com $1 / 3$ de $\mathrm{LiCl} 8 \mathrm{M}$ (concentração final de $2 \mathrm{M}$ ) e incubado overnight a $4^{\circ} \mathrm{C}$. Após a incubação, os tubos foram centrifugados por $15 \min \left(4^{\circ} \mathrm{C}, 13000 \mathrm{rpm}\right)$ e o sobrenadante foi descartado. O pellet foi redissolvido em $400 \mu \mathrm{L}$ de água e reprecipitado com 1/10 de NaOAc (acetato de sódio) $3 \mathrm{M}$ e dois volumes de etanol e incubado por $1 \mathrm{~h} \mathrm{a}-20^{\circ} \mathrm{C}$. Os tubos foram centrifugados $\left(4^{\circ} \mathrm{C}, 10 \mathrm{~min}, 13000 \mathrm{rpm}\right)$ e o sobrenadante descartado novamente. Após a extração, o pellet foi lavado com etanol 70\%, seco e ressuspendido em $50 \mu \mathrm{L}$ de água.

As extrações foram realizadas em quatro repetições, sendo os RNA avaliados em um gel para cada repetição. A quantificação do RNA foi realizada por espectrofotômetro (NanoDrop® ND - 1000 UV-Vis).

A eletroforese foi realizada a $5 \mathrm{~V} / \mathrm{cm}$ por $30 \mathrm{~min}$, em gel de agarose $(1,5 \%)$ desnaturante, com $18 \%$ de formaldeído ( $37 \%$ em água), em tampão TAE 1X. Foram carregados no gel $5 \mu \mathrm{L}$ de RNA em tampão da amostra (20\% de TAE 1X, $50 \%$ de formamida, $10 \%$ de formaldeído (37\% em água), 0,004\% de azul de bromofenol, $20 \%$ de água), na proporção de $5 \mu \mathrm{L}$ de RNA $(1-2 \mu \mathrm{g})$ mais $5 \mu \mathrm{L}$ de tampão. Antes de ser colocada no gel, a solução foi aquecida por $15 \mathrm{~min}$, a $65^{\circ} \mathrm{C}$ e logo resfriada em gelo por $5 \mathrm{~min}$. A cada amostra, foram adicionados $2 \mu \mathrm{L}$ de brometo de etídio $(0,1 \mathrm{mg} / \mathrm{mL})$. As bandas 18 s e 28 s do rRNA foram visualizadas em um transiluminador de UV BioAgency e as intensidades dessas quantificadas por análise de imagem, utilizando programa ImageJ (http://imagej.nih.gov/ij/).

\subsubsection{Análise de RAPD}

Foi utilizado o protocolo descrito por Ferreira e Grattapaglia (1996), com algumas modificações para otimizar a reação para o tipo de amostra avaliada.

As reações de amplificação do DNA continham os seguintes reagentes: 3,0 $\mu \mathrm{L}$ de DNA genômico $(3 \mathrm{ng} / \mu \mathrm{L}), 3,76 \mu \mathrm{L}$ de água deionizada autoclavada, 1,30 $\mu \mathrm{L}$ de tampão 10X para Taq DNA Polimerase, $0,8 \mu \mathrm{L}$ de $\mathrm{MgCl}_{2}(50 \mathrm{mM}), 0,6 \mu \mathrm{L}$ de dNTPs $(10 \mathrm{mM}), 1,04 \mu \mathrm{L}$ de BSA $(10 \mathrm{mg} / \mathrm{mL}), 1,5 \mu \mathrm{L}$ de Primer (Operon Technologies) a $10 \mathrm{ng} / \mu \mathrm{L}$ e $1,0 \mu \mathrm{L}$ de enzima Taq DNA polimerase (Quatro G - $5 \mathrm{U} / \mu \mathrm{L}$ ). Foram utilizados nas análises os seguintes cinco primers: OPA-03, OPA-13, OPF-04, OPF-09, OPH-18. 
As amplificações foram conduzidas em termociclador Veriti® 96-well Thermal Cycle (Applied Biosystems). Foi realizada uma pré-desnaturação a $94^{\circ} \mathrm{C}$, por 5 minutos e, em seguida, 45 ciclos de $94^{\circ} \mathrm{C}$ por 1 minuto, $36^{\circ} \mathrm{C}$ por 1 minuto, $72^{\circ} \mathrm{C}$ por 2 minutos, com extensão final de 15 minutos a $72^{\circ} \mathrm{C}$.

Os fragmentos amplificados foram separados por eletroforese em gel de agarose 1,5\% em tampão TBE $1 \mathrm{X}$, a uma tensão constante de $5 \mathrm{~V} / \mathrm{cm}$ por $2 \mathrm{~h}$, corado com $0,2 \mu \mathrm{g} / \mathrm{mL}$ de brometo de etídio e documentados sob luz ultravioleta. Foi utilizado padrão de peso molecular de $1 \mathrm{~kb}$ para estimar o tamanho dos fragmentos amplificados.

DNAs de embriões de sementes de soja envelhecidas artificialmente por 0h, 48h, $72 \mathrm{~h}$ e $96 \mathrm{~h}$ foram analisadas para se avaliar o polimorfismo entre as amostras e a eficiência do sistema de reparo. A avaliação do sistema de reparo do DNA foi realizada para cada um dos quatro tempos de envelhecimento e três tempos de embebição, 0 h, 14 h e 21 h.

A eficácia da conservação de sementes de cevada à $10^{\circ} \mathrm{C}$, temperatura comumente utilizada em bancos comunitários e coleções de trabalho, foi avaliada. Foram analisadas raízes de cevada (de 2 a $4 \mathrm{~cm}$ ) do acesso BRS Caué, que foi envelhecido artificialmente por $0 \mathrm{~h}, 48$ $\mathrm{h}$ e $96 \mathrm{~h}$. As sementes avaliadas foram estocadas a $10^{\circ} \mathrm{C}$ por três períodos diferentes: 5,9 e 12 meses. Após cada período a $10^{\circ} \mathrm{C}$, as sementes foram armazenadas a $-20^{\circ} \mathrm{C} \mathrm{em}$ freezer, até o momento da germinação para a coleta das raízes. No total, foram analisadas nove amostras de cevada.

Os marcadores foram analisados de acordo com a presença (1) ou ausência (0) de uma determinada banda no gel e organizados em forma de matriz binária, a qual foi utilizada para obtenção de uma dendograma através da análise de agrupamento hierárquica com distância euclidiana e método de ligação Ward no programa de estatística R (https://www.rproject.org/). Para os dados fisiológicos das amostras de cevada, foi avaliada a normalidade pelo teste de Anderson - Darling $(\mathrm{p} \leq 0,05)$ e como as amostras não apresentaram distribuição normal, foi realizado o teste de Kruscal-Wallis $(\alpha \leq 0,05)$ para se avaliar diferenças significativas entre as amostras, também utilizando o programa $\mathrm{R}$.

\subsubsection{Análise em PCR quantitativo (qPCR)}

Para mensurar a integridade do DNA via PCR quantitativo, foi utilizado o StepOne Plus $^{\mathrm{TM}}$ Real Time PCR Systems (Applied Biosystems) equipado com o software StepOne ${ }^{\mathrm{TM}}$ versão 2.2.2, com detecção de fluorescência SYBR Green (Invitrogen). 
O volume final da reação foi de $10 \mu \mathrm{L}$, sendo 5,0 $\mu \mathrm{L}$ de Platinum SYBR Green qPCR Super Mix-UDG w/ROX (Invitrogen), 2,6 $\mu \mathrm{L}$ de água deionizada autoclavada, $0,4 \mu \mathrm{L}$ de solução contendo um par de primers $(10 \mu \mathrm{M})$ e $2 \mu \mathrm{L}$ de DNA (3 ng/ $\mu \mathrm{L})$.

Cada amostra teve duas repetições biológicas, as quais, por sua vez, tiveram, cada uma, duas repetições técnicas. Como controle negativo das reações utilizou-se para cada par de primers o NTC (No template Control) composto pelo mesmo "mix" de reação utilizado nas demais amostras, porém com adição de água ao invés de DNA.

As condições de amplificação foram: $95^{\circ} \mathrm{C}$ por 10 minutos, 40 ciclos de $95^{\circ} \mathrm{C}$ por 15 segundos e $60^{\circ} \mathrm{C}$ por 1 minuto e por fim para ser obter uma curva de dissociação, $95^{\circ} \mathrm{C}$ por 15 segundos, $60^{\circ} \mathrm{C}$ por 1 minuto e $95^{\circ} \mathrm{C}$ por 15 segundos. O resultado da reação foi expresso em valor de CT (valor referente ao número de ciclos necessários para que o sinal o fluorescente atinja o limiar de detecção), calculados no próprio equipamento.

Foram avaliados os pares de primers abaixo desenvolvidos por Murray et al. (2009) para detecção de fragmentação de DNA em soja por qPCR. A sequencia utilizada pelos autores foi do gene TqM_GmTDF (GenBank AB186918), sendo selecionado um primer forward TGGCCTTCTATCCTTCCTCACTC e três reverses:

- AGGATTGGATTTCGGACTCGAT - tamanho do fragmento 86pb;

- CTGCGAGACACGGTAAATGGA - tamanho do fragmento 193pb;

- TATTCGGAATCTCACCGTTGCT - tamanho do fragmento 491pb.

$\mathrm{Na}$ análise dos dados, a normalidade foi avaliada pelo teste de Anderson-Darling e a homogeneidade das variâncias pelo teste de Bartlett, ambos ao nível de significância de $\alpha<$ 0,05. Como os dados não apresentaram distribuição normal foi utilizado o teste de significância não paramétrico de Kruskal-Wallis $(\alpha<0,05)$. Foi realizada análise multivariada pelo agrupamento das amostras, utilizando a distância euclidiana. Todos os testes estatísticos foram realizados em Excel, com suplementação do software de estatística ActionStat ${ }^{\circledR}$ (http://www.portalaction.com.br).

\subsection{RESULTADOS E DISCUSSÃO}

\subsubsection{Avaliação da degradação e reparo do DNA em gel de agarose e eletroforese}

Soja

Os DNA extraídos de sementes de dois cultivares (BRS Flora e BRS 7980) foram avaliados para nível de deterioração em gel de agarose $1 \%$. Como pode ser observado nas Figuras 3.1a e 3.2a, o DNA da soja não apresentou padrão de fragmentação que permitisse a 
identificação de bandas no gel, o que é característico de morte celular programada (Grivicich et al., 2007), dificultando a mensuração do grau de deterioração do DNA. Kranner et al. (2011) analisando DNAs de lotes de ervilhas com diferentes poderes de germinação, obtidos também por envelhecimento artificial, observaram bandas em gel de agarose que aumentaram de intensidade conforme o poder de germinação diminuía, o que permitiu estimar o nível de degradação entre os lotes. Entretanto, não são todas espécies que apresentam esse padrão de fragmentação do DNA. Por exemplo, Vicente et al. (2016) e Radha et al. (2014) também não observaram bandas de DNA de sementes de Ocotea puberula e Zea mays, respectivamente, em armazenamento por diferentes períodos.

Uma vez que a avaliação da degradação do DNA não foi possível em gel de agarose, , foi avaliado o potencial do DNA degradado de soja, visualizado como um "borrão", para diferenciar seu nível de deterioração. A intensidade do "borrão" abaixo do DNA íntegro no gel de eletroforese foi avaliada, mas não foi observado aumento da deterioração do DNA do cv Flora conforme o aumento do tempo de envelhecimento (Figura 3.1). O fato de se não observar variação na intensidade da fluorescência do "borrão" do cv Flora pode ser devido à baixa qualidade das sementes, as quais já apresentavam germinação inicial (68\%), valor esse abaixo do recomendado, que é 85\% (Marcos-Filho, 1999). Uma vez que a analise do DNA degradado não foi informativo em gel de agarose, o experimento foi repetido, isto é, sementes de soja cv BRS 7980 foram envelhecidas por 0, 6, 12, 24, 48, 72 e 96h, embebidas por 0, 7, 14 e 21 h e seus DNA extraídos e avaliados em gel de agarose.

Uma maior deterioração do DNA e reduções de intensidade de fluorescência da deterioração do DNA ("borrão") entre os tempos de embebição puderam ser observadas em 48h, 72 h e 96 h de envelhecimento (Figura 3.2a) (Figura 3.2b). Entretanto, essa variação só foi estatisticamente significativa na amostra $48 \mathrm{~h}$.

Apesar das evidências de reparo de DNA no tratamento $48 \mathrm{~h}$, as duas maneiras de análise da degradação (visual e quantificação da intensidade do borrão), foram pouco conclusivas e não poderiam ser utilizadas para a avaliação da integridade do DNA durante o envelhecimento. 


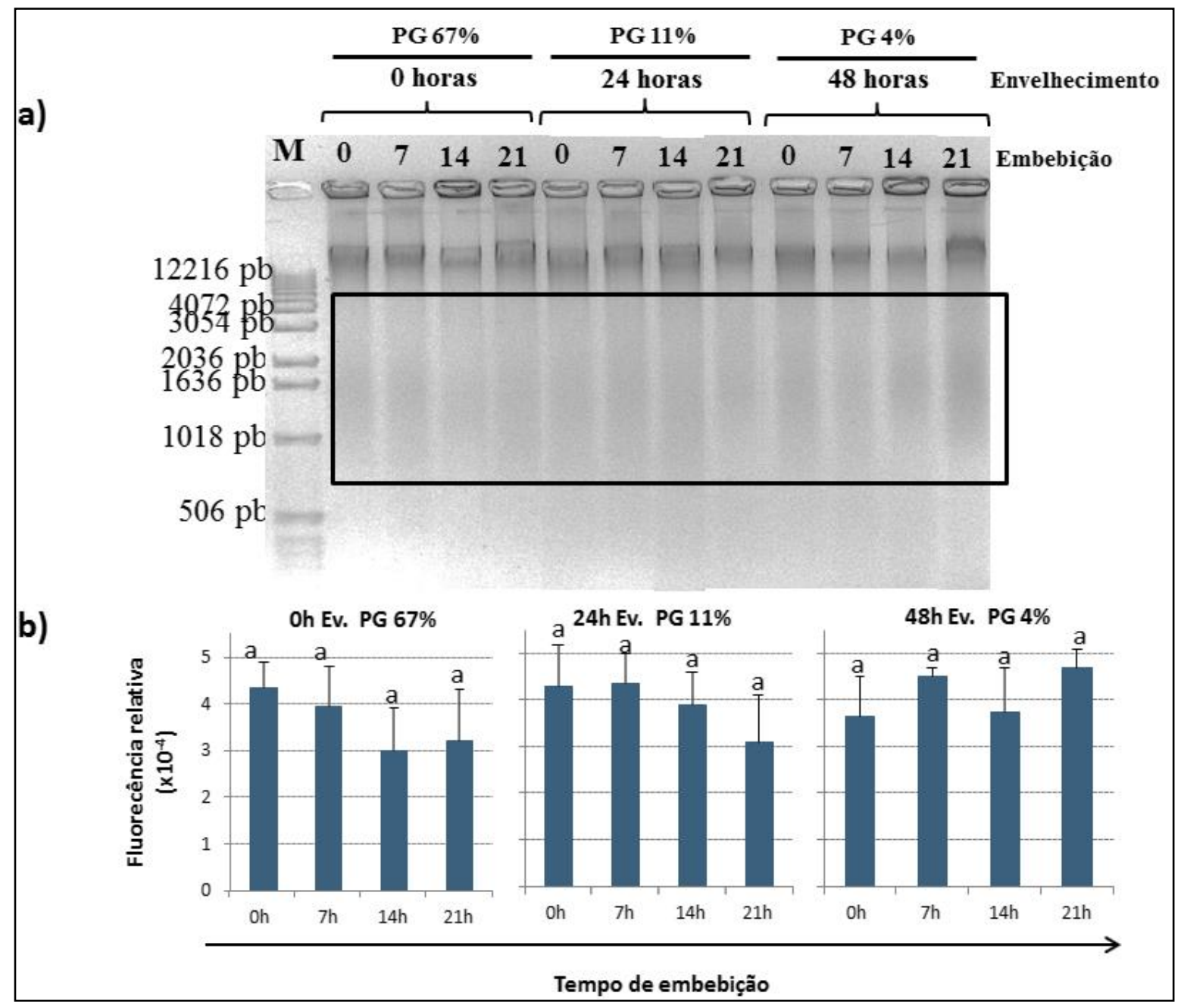

Figura 3.1. Análise do DNA das sementes de soja cv BRS Flora envelhecidas artificialmente: a) Gel de eletroforese das sementes de soja envelhecidas por três tempos (Ev) e com seis tempos de embebição (Eb), M - marcador $1 \mathrm{~kb}$ (Invitrogen), b) Análise semi-quantitativa da degradação do DNA pela intensidade de fluorescência do "borrão" (área do retângulo) de duas repetições biológicas. Barras seguidas de mesma letra dentro de um mesmo grupo de envelhecimento não diferem de acordo com o teste de Kruskal-wallis ( $\mathrm{p} \leq 0,05)$. PG = germinação. 


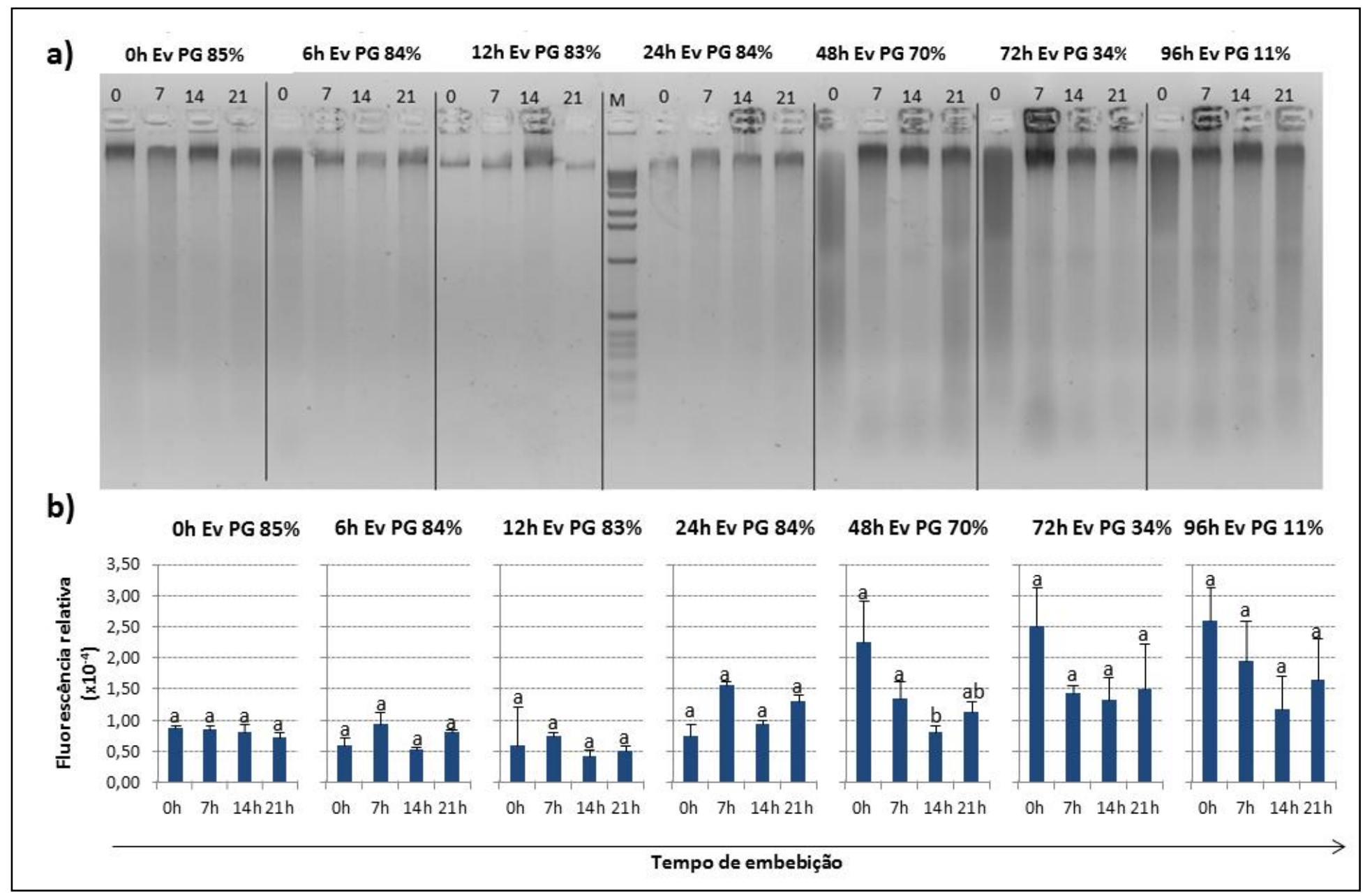

Figura 3.2. Análise do DNA dos embriões da soja $c v$ BRS 7980: a) Gel de eletroforese com sete tempos de envelhecimento e quatro diferentes tempos de embebição. Amostras: $M$ - ladder (Invitrogen), b) Análise semi-quantitativa da degradação do DNA pela intensidade de fluorescência do "borrão", de duas repetições. Barras seguidas de mesma letra dentro de um mesmo grupo de envelhecimento não diferem de acordo com o teste de Kruskal-wallis $(\mathrm{p} \leq 0,05)$. PG = germinação. 


\section{$\underline{\text { Cevada }}$}

A maioria dos DNAs avaliados apresentaram bandas detectáveis em gel de agarose, inclusive os DNA de algumas repetições da amostra controle, isto é, das sementes não submetidas ao envelhecimento (Figura 3.3). A presença de fragmentação do DNA em gel de agarose de sementes controles também foi observada por Kranner et al. (2011), o que mostra que não necessariamente uma amostra controle não apresentará fragmentação do DNA.

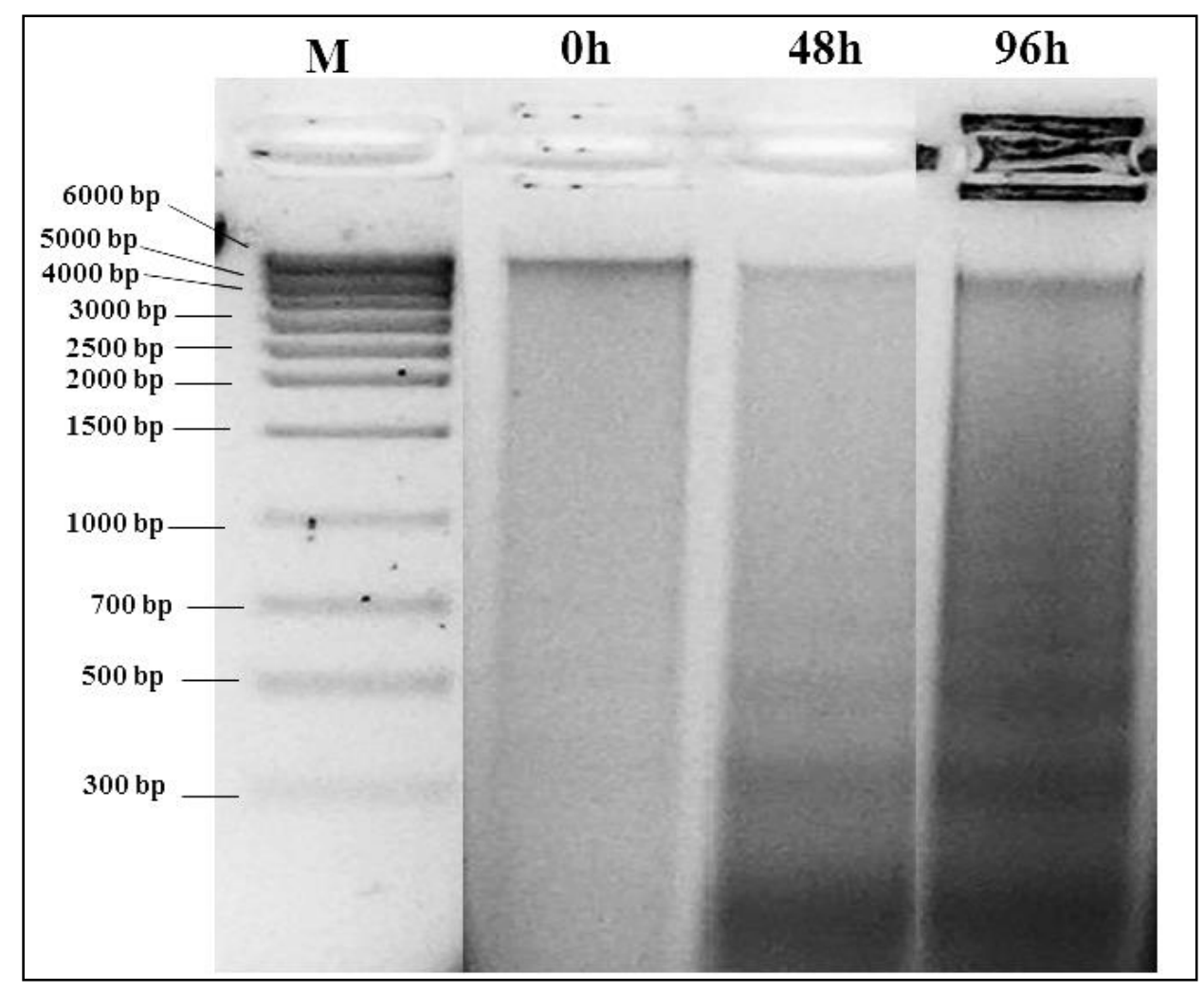

Figura 3.3. Gel de eletroforese do DNA das sementes envelhecidas por três diferentes tempos e três tempos de embebição. Amostras: $M$ - ladder $1 \mathrm{~kb}$, Norgen, DNA de sementes controle, DNA de sementes envelhecidas por 48h, DNA de sementes envelhecidas por 96h. Observa-se que a intensidade da fluorescência dos fragmentos de DNA nas amostras aumenta conforme o maior tempo de envelhecimento.

Entre os fragmentos detectados foi escolhido um fragmento de aproximadamente 400 pb para avaliar a deterioração do DNA entre os tratamentos e entre os tempos de embebição, dentro de cada tratamento. No geral, a intensidade da fluorescência do fragmento foi maior nas sementes mais envelhecidas (96h), sugerindo que a fragmentação do DNA detectada foi devida ao envelhecimento acelerado e não houve variação entre os tempos de embebição de cada tempo de envelhecimento (Figura 3.4). 


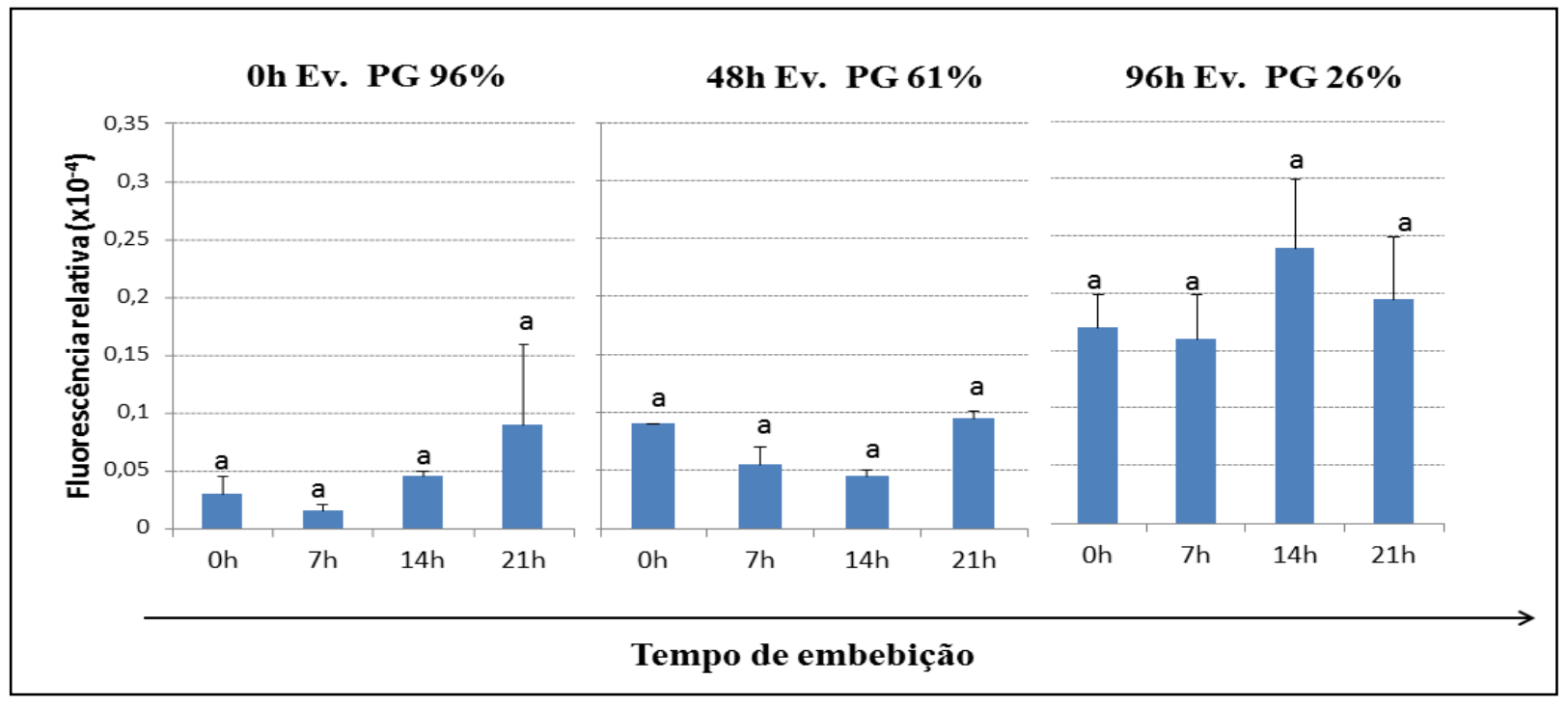

Figura 3.4. Análise semi-quantitativa da deterioração do DNA das sementes de cevada por análise da intensidade de fluorescência de um fragmento de $\sim 400 \mathrm{pb}$ de duas repetições biológicas. Barras seguidas de mesma letra dentro de um mesmo grupo de envelhecimento não diferem de acordo com o teste de Kruskal-wallis $(p \leq 0,05) . P G=$ germinação. Maiores intensidades da fluorescência da fragmentação foram observadas na amostra com 96 h de envelhecimento.

No geral, o gel de agarose não foi uma boa metodologia para avaliação da deterioração do DNA de sementes envelhecidas para a soja, pois não foi observado padrão de bandas na fragmentação do DNA e sim de um "borrão", o que dificultou a delimitação da área a ser quantificada. Foi observado tanto para soja como para cevada um aumento da degradação, mas sem significância estatística. Garcia (2012) também não observou diminuição na integridade de DNA de sementes de Araucaria angustifólia entre lotes sem viabilidade.

Para a cevada, que apresentou padrão de bandas na fragmentação do DNA, a quantidade de DNA carregado nos poços do gel de agarose pode ter contribuído para a baixa reprodutibilidade do método, pois nesse estudo foram carregados de 2 a $3 \mu \mathrm{g}$ de DNA nos poços do gel de agarose e na literatura há dados mostrando o surgimento do padrão de bandas devido ao envelhecimento das sementes com de 5 a $10 \mu \mathrm{g}$ de DNA no gel para cada tratamento (Faria et al., 2005; El-Maarouf-Bouteau et al., 2011). Essa quantidade de DNA chega a 3 x mais ao que foi empregado neste estudo, consequentemente necessitaria de $3 \mathrm{x}$ mais a quantidade de sementes utilizadas, o que seria incompatível com a rotina de monitoração de um banco de germoplasma. 
A quantificação do DNA oriundo de sementes também contribuiu para a baixa reprodutibilidade do método, tanto para as sementes de soja como também para as de cevada, pois as impurezas interferem na quantificação (Ver Capitulo 2). Foram testadas lavagens extras com CIA, adição de fenol, proteinase K (dados não mostrados) na tentativa de se obter DNAs mais puros. Foi observada diminuição nas impurezas, mas o pellet continuou visivelmente sujo. Pellet consideravelmente mais limpo foi obtido por meio da extração do DNA apenas de embriões no caso da soja e essa foi a metodologia utilizada durante o trabalho para essa espécie.

O teste de quantificação realizado (ver Capítulo 2) mostrou que ainda havia muita impureza e que estas prejudicavam a quantificação por espectrometria de absorbância. A purificação do DNA em colunas de purificação poderia resolver esse problema, mas o custo não seria compatível com o volume das análises que tem que ser realizada num banco de germoplasma em função do grande número de acessos em conservados.

\subsubsection{Avaliação da integridade do RNA por gel de agarose e eletroforese}

O rRNA analisado, assim como os demais que existem semente, foi sintetizado durante sua formação e não houve síntese de novo RNA, pois as sementes não passaram por germinação. Tais RNAs são fundamentais na germinação que pode ser comprometida com a perda de sua integridade (Das et al., 2015) e por isso a avaliação do mesmo tem potencial para contribuir no processo de monitoramento em bancos de germoplasma.

A metodologia mais adequada para as sementes de soja e cevada foi a proposta por Wang e Vodking (1994), pois permitiu a extração de maior quantidade de RNA $(2,7 \mu \mathrm{g})$ utilizando-se duas sementes de soja com maior nível de pureza (Tabela 3.1). Para as sementes de cevada, a melhor metodologia testada foi a de Wang et al. (2012), porém ainda com uma quantidade de RNA insuficiente para a visualização no gel das bandas 28 e 18 s o que impossibilitou a análise dessa espécie (Tabela 3.1). A metodologia de Dan e Chen (2013), apesar de extrair uma quantidade menor de RNA em relação à metodologia de Wang e Vodking, também mostrou ser uma metodologia interessante, pois com ela obteve-se quase 2 $\mu \mathrm{g}$ de RNA para soja e aproximadamente 240 ng para cevada e ambos com altos níveis de pureza, além de se poder extrair DNA ao mesmo tempo em que RNA separando os dois nas etapas finais do método (Tabela 3.1). Entretanto, a metodologia utilizada neste estudo foi a de Wang e Vodking (1994), porque possibilitou uma maior quantidade de RNA e o tempo de extração foi mais curto do que a metodologia proposta por Dan e Chen (2013). 
Tabela 3.1. Concentrações de RNA nas sementes inteiras de soja (duas sementes) e cevada (cinco sementes) obtidas de diferentes métodos de extração.

\begin{tabular}{ccccc}
\hline Amostra & $\mathbf{n g} / \boldsymbol{\mu L}$ & $\mathbf{2 6 0 / 2 8 0}$ & $\mathbf{2 3 0 / 2 8 0}$ & Metodologia \\
\hline Soja & 50 & 0,59 & 0,56 & \multirow{2}{*}{ Chang et al. (1993) } \\
Cevada & 245 & 1,68 & 0,47 & \\
Soja & 1980,7 & 2,14 & 2,33 & \multirow{2}{*}{ Dan e Chen (2013) } \\
Cevada & 241,7 & 1,92 & 1,85 & \\
\hline Soja & 107,9 & 1,98 & 1,85 & \multirow{2}{*}{ Mornkham et al. (2013) } \\
Cevada & 242,4 & 1,96 & 1,84 & \\
\hline Soja & 897,2 & 2,09 & 2,16 & \multirow{2}{*}{ Wang et al. $(2012)$} \\
Cevada & 224,9 & 1,98 & 1,87 & \\
\hline Soja & 2775,1 & 2,02 & 2,23 & \multirow{2}{*}{ Wang e Vodking (1994) } \\
Cevada & 186,6 & 1,97 & 1,44 & \\
\hline Soja & 6,6 & 2,56 & 0,24 & \multirow{2}{*}{ Zarei et al. (2012) } \\
Cevada & 85,9 & 2,04 & 1,02 & \\
\hline
\end{tabular}

A degradação do RNA pode causar perda ou redução de viabilidade, porque compromete a síntese de proteínas necessárias para o bom desenvolvimento da plântula (Fu et al., 2015). Portanto, a avaliação da integridade do RNA em sementes pode contribuir no entendimento do processo de perda da germinação e no monitoramento desse processo. Esperava-se uma correlação entre a germinação e a integridade do RNA, assim como foi observado em sementes de ervilha envelhecidas artificialmente (Kranner et al., 2011), mas no geral a intensidade da fluorescência das bandas $28 \mathrm{~s}$ e $18 \mathrm{~s}$ do rRNA não apresentaram diferença estatística.

Diminuição da intensidade da banda $18 \mathrm{~s}$ do tratamento $48 \mathrm{~h}$ em relação ao controle (0h) foi observada apenas para a soja cv BRS Flora (Figura 3.5 esquerda a e b). Não houve diferença entre o tratamento $24 \mathrm{~h}$, controle e $48 \mathrm{~h}$ de envelhecimento artificial. A banda $28 \mathrm{~s}$ não apresentou diferença significativa ou estatística entre nenhum dos tratamentos.

As sementes da soja cv BRS 7980 apesar de envelhecidas por mais tempo que $48 \mathrm{~h}$, no geral, também não apresentaram diferença estatística entre os tratamentos. Foi encontrada queda da intensidade da banda 28s apenas no tratamento 96 h em relação às demais amostras, menos para a amostra de 72 e 24 h de envelhecimento (Figura 3.5 direita a e b). Assim, como no experimento anterior, não foi encontrada variação entre as amostras para a banda 18s.

A quantidade de RNA foi estável entre os tratamentos de envelhecimento, não apresentando queda na concentração (Figura 3.6), divergindo dos dados obtidos por Kranner et al. (2011) que observaram uma relação negativa entre a quantidade de RNA na semente e o 
tempo de envelhecimento artificial, sendo maior o tempo de envelhecimento menor a quantidade de RNA, chegando a redução de mais de 50\% para as amostras com $2 \%$ de germinação. A diferença nos resultados pode ter sido em função da menor quantidade de RNA de cada amostra analisada, que é consequência da dificuldade de extração de grande quantidade de RNAs de sementes de soja com os métodos testados.

Comparando os dois cultivares de soja, observa-se que as intensidades de fluorescência das bandas $18 \mathrm{~s}$ do $\mathrm{cv}$ Flora foram mais baixas em todos os tempos de envelhecimento do que as do cv BRS 7980, sugerindo que as sementes do cv Flora já estavam com baixa qualidade antes do tratamento de envelhecimento. Isso corrobora com os dados obtidos no teste de germinação no Capítulo 1, que também mostrou baixa qualidade das sementes do cv Flora.

Observando os gráficos da intensidade de fluorescência das bandas 18 e 28s do rRNA das duas cultivares de soja, percebe-se que as bandas do rRNA 18s apresentaram maior fluorescência do que as bandas 28s. Isso é um indicativo de que o RNA não está íntegro (Imbeaud et al., 2005). Entretanto, esse fato ocorreu em todas as amostras, incluindo as controles, o que indica que durante a extração ocorreu dano ao RNA e isso refletiu na sua qualidade na visualização no gel de agarose. É provável que este dano tenha ocorrido por oxidação, porque o RNA, em parte, é mais propicio a oxidação do que o DNA devido a sua estrutura de uma única fita simples (Waterworth et al., 2016).

Chen et al. (2013) assim como Kranner et al. (2011), também encontraram gradual desaparecimento das bandas 18 e $28 \mathrm{~s}$ do rRNA em sementes de ervilha envelhecidas artificialmente por diferentes tempos. Esse dado corrobora com a ideia de que, a não visualização de diferenças entre as amostras em relação à integridade do rRNA, deva ser devido a danos ao RNA durante a extração do mesmo. 


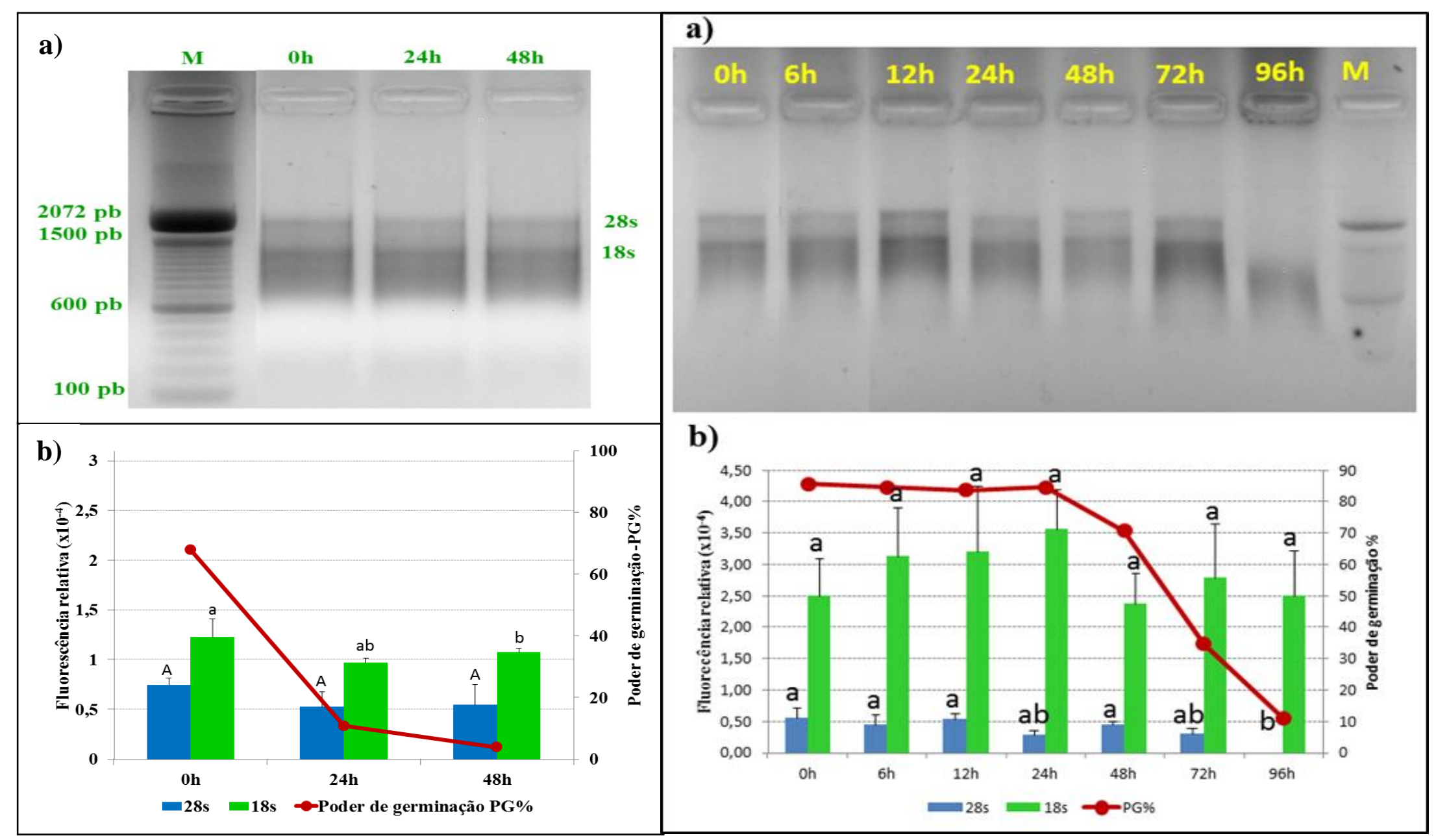

Figura 3.5. Análise do RNA das sementes de soja. Esquerda: cv BRS Flora e direita cv BRS 7980. a) Gel de eletroforese das sementes envelhecidas, com 400 ng de RNA em cada poço, linha $M$ - ladder 100pb, b) Análise semi-quantitativa da deterioração do RNA por análise da intensidade de fluorescência das bandas 28s e 18s rRNA . 


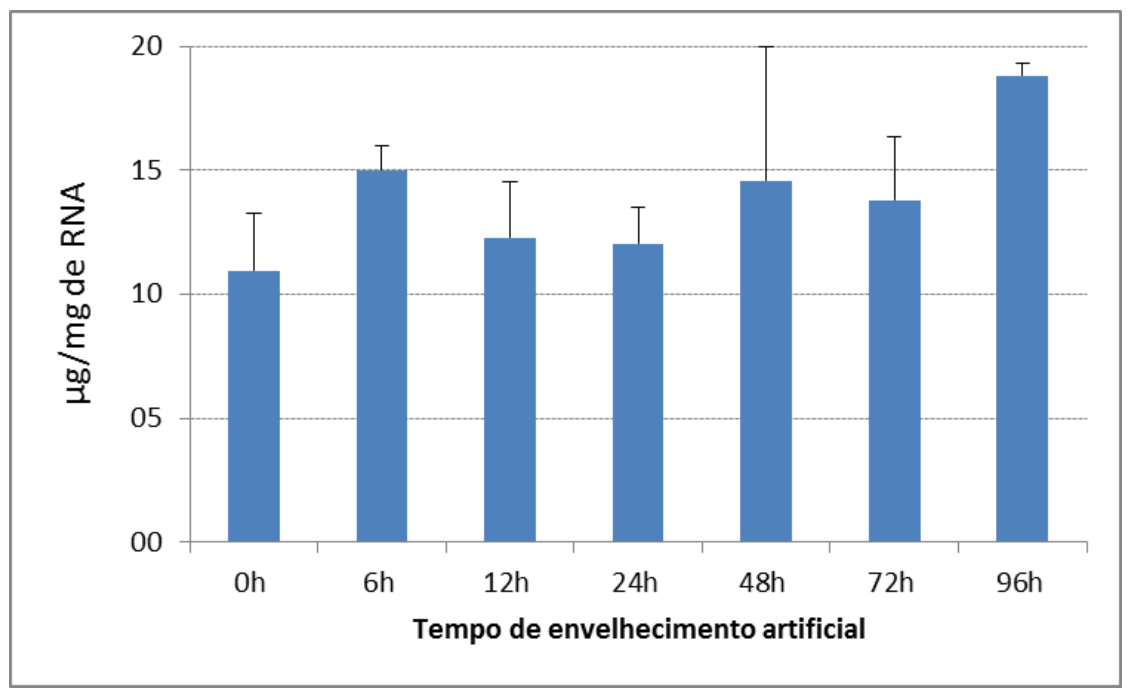

Figura 3.6. Variação da concentração do RNA durante o envelhecimento acelerado de sementes de soja.

\subsubsection{Avaliação do sistema de reparo do DNA e introdução de variabilidade} utilizando-se marcadores RAPD

RAPD foi utilizado para analisar se o envelhecimento pode introduzir variabilidade genética nas amostras e se pode ser utilizado para avaliar o reparo do DNA.

\section{$\underline{\text { Padronização }}$}

Foram realizados testes para a padronização da metodologia para o tipo de material estudado. Na Figura 3.7 encontra-se o resultado de um teste realizado para avaliar a amplificação utilizando-se diferentes concentrações de componentes da reação de PCR com o primer OPF09. As melhores concentrações foram as seguintes: DNA $5 \mathrm{ng} / \mu \mathrm{L}$, total de $15 \mathrm{ng}$ por reação, primer $10 \mathrm{ng} / \mu \mathrm{L}, \mathrm{MgCl}_{2} 2,5 \mathrm{mM}$ e $3,1 \mathrm{mM}$, sendo que as concentrações mais baixas $(1,5 \mathrm{mM})$ e mais altas $(4,6 \mathrm{mM})$ prejudicaram a amplificação, a concentração ideal de BSA foi $0,8 \mathrm{mg} / \mu \mathrm{L}$. Foram testadas várias concentrações de Taq polimerase e a concentração ideal de enzima foi o de 5 U/reação. Os motivos para uso de uma maior concentração de Taq podem ser vários, como o lote da enzima e contaminação do com produtos que inibem a ação dessa enzima. A Figura 3.8 apresenta os géis resultantes da padronização da metodologia para o primer e $\mathrm{MgCl}_{2}$. 


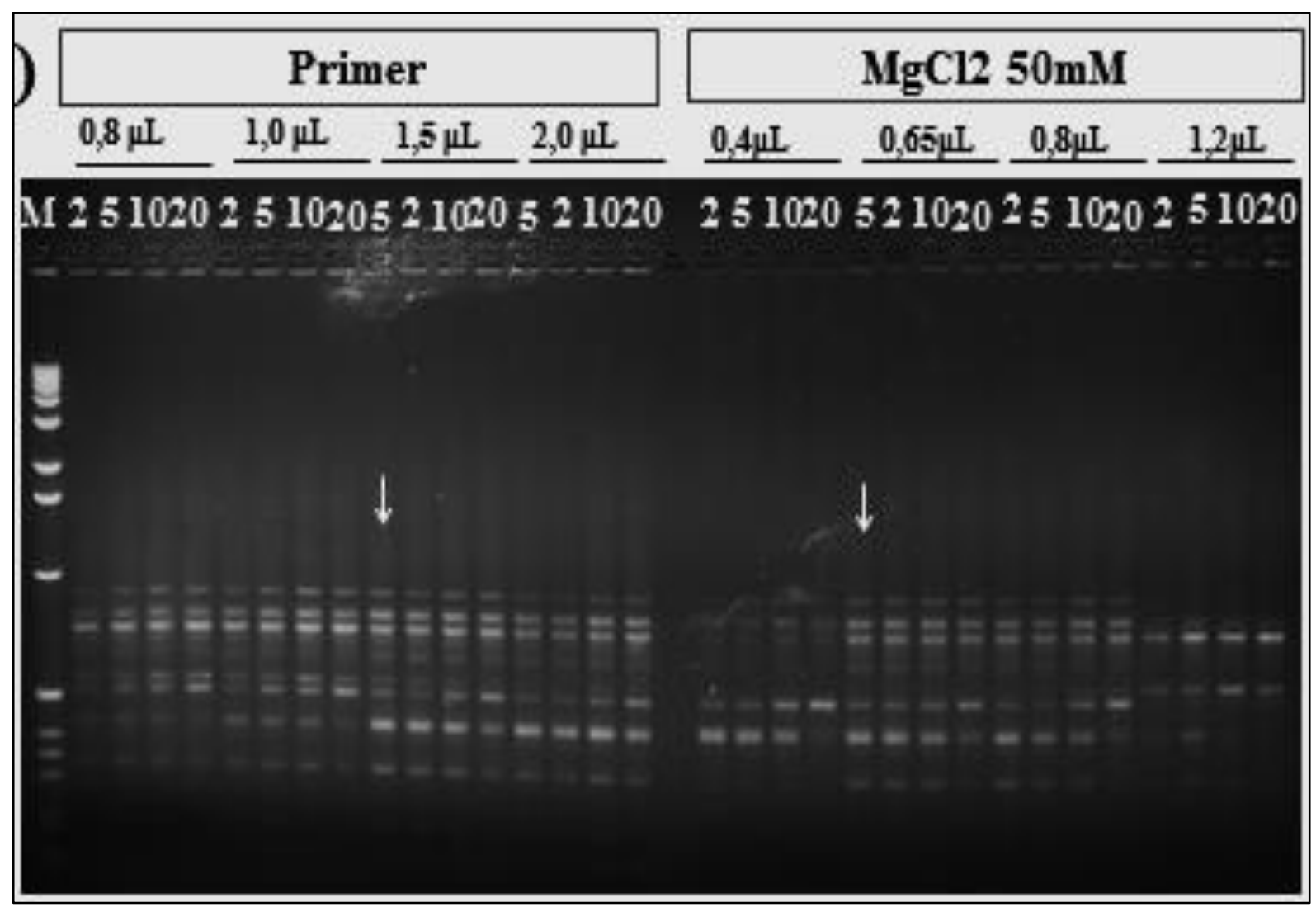

Figura 3.7. Padronização da metodologia de RAPD com o primer OPF09: diferentes volumes da solução de primer (10 ng/ $\mu \mathrm{L})$ e de concentração $\mathrm{MgCl}_{2}$ e As concentrações do DNA foram respectivamente $2,5,10$ e $20 \mathrm{ng} / \mu \mathrm{L}$. Setas indicam a melhor condição observada.

Detecção de polimorfismo entre amostras de soja e cevada envelhecidas artificialmente por diferentes tempos

\section{Soja}

Foram utilizados nas amplificações DNAs extraídos de embriões de sementes de soja envelhecidas por 0, 48, 72 e 96 h e cinco primers. Foram detectados 34 fragmentos no total, sendo que 20 foram polimórficos. $\mathrm{O}$ número de fragmentos amplificados variou de quatro para o primer OPH18 a nove para o primer OPA13, sendo o mais informativo o OPA3 (oito bandas totais, sendo cinco polimórficas).

Foi observado nas amostras envelhecidas de soja o desaparecimento de bandas, sendo mais frequentes com bandas acima de $300 \mathrm{pb}$ e o surgimento de novas bandas, que foi mais frequente com bandas abaixo de $300 \mathrm{pb}$ (Tabela 3.2). Esse dado sugere que quanto maior o fragmento maior a probabilidade de haver alguma alteração entre os sítios de anelamento dos primers que leve a não amplificação do fragmento. Murray et al. (2009) observaram que a 
variação entre o nível de degradação de diferentes amostras de soja pôde ser melhor evidenciado, utilizando-se qPCR, a medida que foram analisados fragmentos com tamanhos maiores. Portanto, os sugerem que RAPDs podem auxiliar na caracterização do nível de degradação de DNA obtidos de sementes em diferentes graus de envelhecimento.

Tabela 3.2 Variação no número de bandas para as amostras de soja após envelhecimento para os cinco primers avaliados.

\begin{tabular}{lll}
\hline Tamanho do fragmento & Bandas ausentes & Bandas novas \\
\hline$\leq 220 \mathrm{pb}$ & 0 & 5 \\
$>220$ a $300 \mathrm{pb}$ & 0 & 1 \\
$>300$ a $500 \mathrm{pb}$ & 7 & 0 \\
$>500$ a $900 \mathrm{pb}$ & 3 & 4 \\
\hline
\end{tabular}

As relações entre as amostras, levando-se em conta o compartilhamento de fragmentos, estabelecidas por análise de agrupamento hierárquico baseada em matriz de distância são apresentadas na Figura 3.8a. Foram detectados três grupos sendo o primeiro formado pela amostra controle (0h), o segundo pelas amostras 48 e $72 \mathrm{~h}$ e o terceiro pela amostra 96h. A variação encontrada entre as amostras foi devida exclusivamente à diferença nas integridades do DNAs, uma vez que o genótipo é exatamente o mesmo, pois se trata um acesso de soja, que é uma espécie autógama. Isso demonstra que o RAPD pode ser utilizado para se estimar diferenças de integridade de DNA entre amostras e que essas diferenças são causadas pelo envelhecimento. Com marcadores RAPD, Vijay et al. (2009), analisaram amostras de soja e girassol envelhecidas naturalmente e artificialmente e obtiveram grupos distintos entre elas, os mesmos autores tiveram resultados semelhantes com o uso de marcadores tipo SSR e AFLP. Donà et al. (2013) também analisando amostras envelhecidas e controle para sementes de Silene sp. por RAPD também obtiveram grupos distintos entre as amostras envelhecidas e não envelhecidas e indicam o uso deste como ferramenta para avaliar a integridade de sementes estocadas em longo prazo.

A técnica de RAPD tem baixo custo em relação às demais, o que a torna interessante para implementação em banco de germoplasma, onde número de amostras a serem analisadas pode ser bastante alto, elevando o custo. Por ser uma técnica baseada em PCR, tem como vantagem também a utilização de pequenas quantidades de amostras. A única desvantagem 
dessa técnica seria a incapacidade de distinguir entre quebras simples e duplas na fita do DNA, pois ambas resultam em não amplificação exponencial.

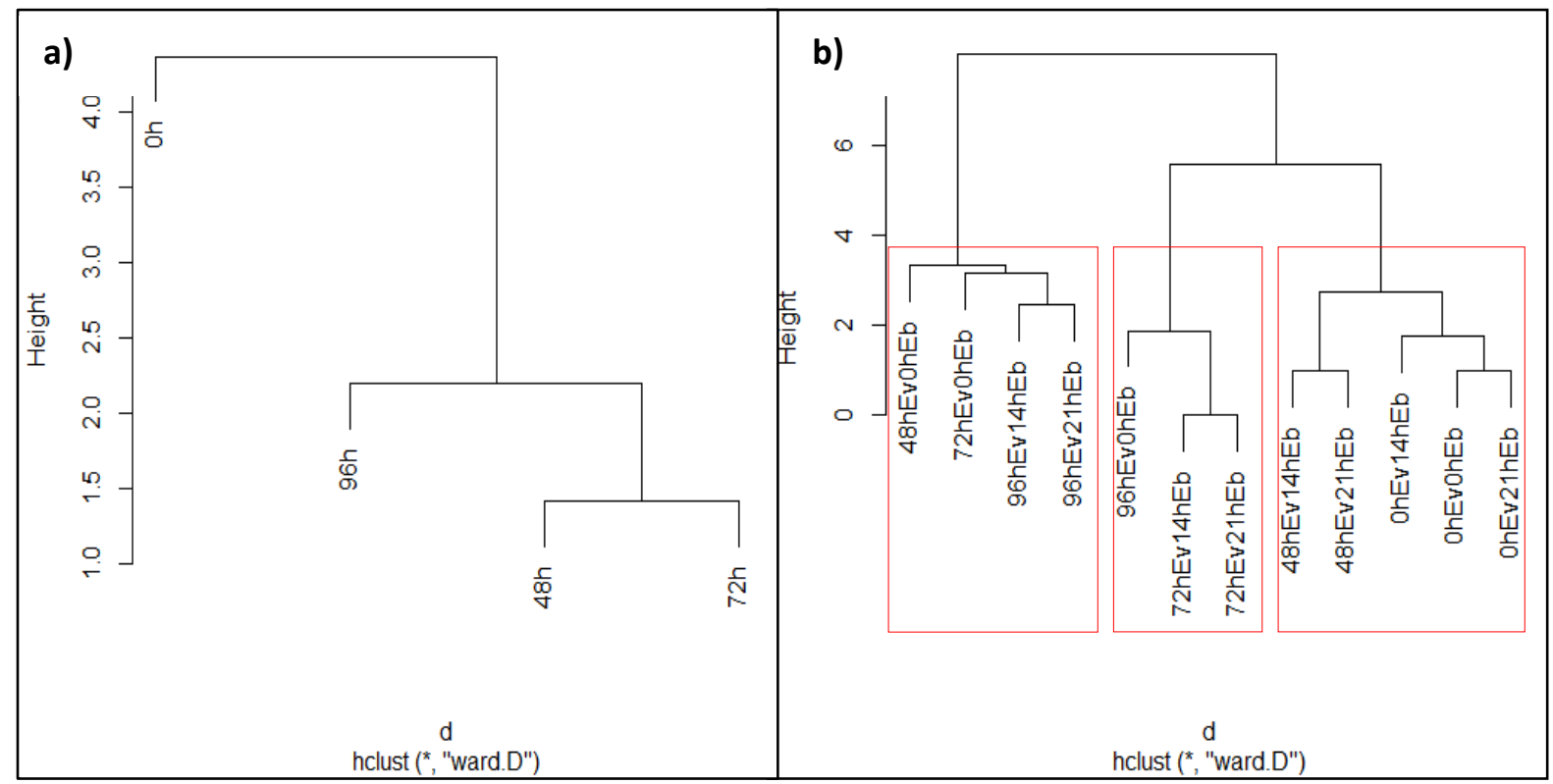

Figura 3.8. Análise de agrupamento para as amostras de soja: a) agrupamento apenas das amostras envelhecidas, sem embebição e b) agrupamento das amostras envelhecidas, mais o tempo de embebição.

O sistema de reparo em sementes de soja também foi avaliado por RAPD utilizando-se as sementes envelhecidas por diferentes tempos $(0 \mathrm{~h}, 48 \mathrm{~h}, 72 \mathrm{~h}$ e $96 \mathrm{~h})$ e três tempos de embebição (0 h 14 h e 21 h). Como pode ser observado na Figura 3.8b, as amostras foram divididas em três clusters, sendo o primeiro formado pelas amostras controle e as amostras envelhecidas por $48 \mathrm{~h}$ e embebidas por 14 e $21 \mathrm{~h}$, o segundo pela amostra envelhecida por $96 \mathrm{~h}$ e 0 h de embebição e as de $72 \mathrm{~h}$ com 14 e $21 \mathrm{~h}$ de embebição e o terceiro pelas amostras controle de embebição de 48 e 72 h de envelhecimento e as de 14 e 21 h de embebição do tratamento $96 \mathrm{~h}$ de envelhecimento.

$\mathrm{O}$ agrupamento de amostras controle e envelhecidas por $48 \mathrm{~h}$ demonstram que o reparo ocorreu e que ele pode ser detectado via RAPD. As variações observadas entre as amostras deste cluster, principalmente as controles, sugerem que o reparo não foi $100 \%$ eficiente a ponto das amostras terem o mesmo padrão do controle e/ou que os padrões obtidos com RAPD podem ser variáveis mesmo entre amostras 100\% idênticas geneticamente, em função de diferentes fatores, como quantidade e qualidade de DNAs entre amostras. 
No geral, a distância entre controle e testes após embebição diminuíram à medida que o tempo de envelhecimento também diminui, demonstrando diferenças na capacidade de reparo em função do tempo de envelhecimento. O mesmo foi demonstrado por Kranner et al . (2011) utilizando a comparação entre a intensidade de bandas de DNA degradado de sementes de ervilha envelhecidas, em gel de agarose corados com brometo. Essa comparação só foi possível porque o padrão de degradação de DNA de sementes de ervilha é o observado em morte celular programada, que leva a degradação do DNA em pontos específicos, o que leva a visualização de bandas no gel. Em embriões de soja, a morte celular programada não foi detectada e por isso nenhum padrão de banda foi visualizado, apenas um "borrão", o que dificultou a comparação entre as amostras, como pode ser visto na Figura 3.2.

O surgimento de bandas maiores que $300 \mathrm{pb}$, que nem sempre estavam presentes na amostra controle e o desaparecimento de bandas menores que $200 \mathrm{pb}$ foram observados nas amostras 48 e 72 h após embebição (Tabela 3.2 e Figura 3.9). O surgimento e desaparecimento de bandas após o reparo indicam que a sequência de nucleotídeo foi alterada de alguma maneira. Adeboye et al. (2015) sugeriram, após o surgimento de variações entre amostras de arroz envelhecido artificialmente, que essas variações podem levar a perda de alelos. Chauhan e Swaminathan (1984) observaram significativa queda na viabilidade de grãos de pólen de soja e cevada que passaram por envelhecimento acelerado, indicando que o envelhecimento pode causar alterações que podem ser passadas para a geração seguinte. 


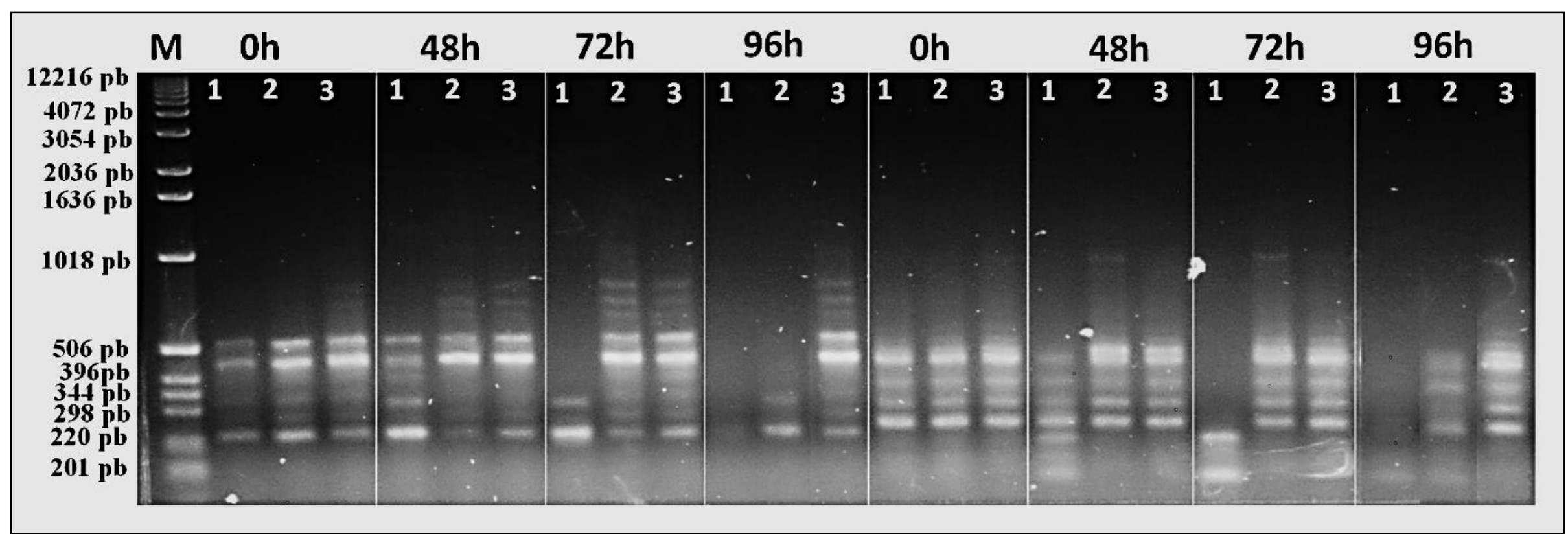

Figura 3.9. Variação no padrão de bandas ao longo do envelhecimento e embebição $(1=0$ h, $2=14$ h e $3=21$ h). Primers OPA 3 e OPA13 respectivamente. Foi observado o desaparecimento de bandas maiores de 300 pb com o envelhecimento, que foram restabelecidas depois de 14 horas de embebição. Observou - se também o surgimento de novas bandas menores de 200 pb com o envelhecimento , as quais desapareceram após 


\section{$\underline{\text { Cevada }}$}

A conservação de recursos genéticos a $10^{\circ} \mathrm{C}$ acontece em alguns bancos ativos de germoplasma, que não dispõem de câmaras com temperatura de $-20^{\circ} \mathrm{C}$ e, por isso avaliação do impacto da conservação nessa temperatura é muito importante.

A variabilidade introduzida pelo envelhecimento e a influência da conservação a $10^{\circ} \mathrm{C}$ foram avaliadas utilizando-se DNA de raízes de sementes envelhecidas por 0,48 e $96 \mathrm{~h}$ e conservadas a $10^{\circ} \mathrm{C}$ por três períodos diferentes:

- $\mathrm{P} 1=5$ meses;

- $\mathrm{P} 2=9$ meses; e

- $\mathrm{P} 3=12$ meses.

Após os períodos de conservação à $10^{\circ} \mathrm{C}$, as amostras foram conservadas a $-25^{\circ} \mathrm{C}$ até o momento da germinação, para a coleta das raízes.

Os dados da germinação (G\%) e índice de velocidade (IVG) para os três tempos de envelhecimento e os três períodos de armazenamento são apresentados na Tabela 3.3. Foram observadas diferenças significativas entre os tempos de envelhecimento 0 h, 48 h e 96 h, a qual foi mantida nos três períodos de armazenamento. Apenas o IVG foi reduzido após nove e doze meses de armazenamento a $10^{\circ} \mathrm{C}$ na amostra controle.

Pelos dados fisiológicos, percebe-se que o armazenamento à $10^{\circ} \mathrm{C}$ não foi prejudicial às sementes, porque a geminação foi mantida, independente da qualidade inicial do lote. Esse resultado é muito interessante para os bancos germoplasma comunitários, que conservam sementes crioulas e alguns bancos ativos, pois estes nem sempre possuem equipamentos para manter as sementes em uma temperatura mais baixa.

Tabela 3.3. Análise fisiológica das sementes de cevada utilizadas na análise de RAPD.

\begin{tabular}{cccc}
\hline Período a $10^{\circ} \mathrm{C}$ & Envelhecimento & $\mathrm{G} \%$ & IVG \\
\hline \multirow{3}{*}{ P1 = 5 meses } & $0 \mathrm{~h}$ & $97 \pm 2,2^{\mathrm{a}}$ & $22,5 \pm 0,7^{\mathrm{a}}$ \\
& $48 \mathrm{~h}$ & $52 \pm 6,4^{\mathrm{b}}$ & $10,0 \pm 1,4^{\mathrm{b}}$ \\
& $96 \mathrm{~h}$ & $21 \pm 4,6^{\mathrm{c}}$ & $4,1 \pm 0,8^{\mathrm{c}}$ \\
\hline \multirow{3}{*}{$\mathrm{P} 2=9$ meses } & $0 \mathrm{~h}$ & $94 \pm 1,4^{\mathrm{a}}$ & $18,4 \pm 0,3^{\mathrm{a}^{*}}$ \\
& $48 \mathrm{~h}$ & $61 \pm 9,2^{\mathrm{b}}$ & $10,1 \pm 1,6^{\mathrm{b}}$ \\
& $96 \mathrm{~h}$ & $30 \pm 5,9^{\mathrm{c}}$ & $5,2 \pm 0,9^{\mathrm{c}}$ \\
\hline \multirow{3}{*}{$\mathrm{P} 3=12$ meses } & $0 \mathrm{~h}$ & $97 \pm 2,2^{\mathrm{a}}$ & $18,9 \pm 0,3^{\mathrm{a}^{*}}$ \\
& $48 \mathrm{~h}$ & $58 \pm 7,5^{\mathrm{b}}$ & $8,6 \pm 1,0^{\mathrm{b}}$ \\
& $96 \mathrm{~h}$ & $23 \pm 2,5^{\mathrm{c}}$ & $3,2 \pm 0,7^{\mathrm{c}}$ \\
\hline
\end{tabular}

G\% - germinação e IVG - índice de velocidade de germinação. Colunas com mesma letra não diferem entre si em relação ao tempo de envelhecimento de acordo com o teste de Kruscal- Wallis $(\alpha \leq 0,05)$. O asterisco indica diferença entre os períodos de armazenamento a $10^{\circ} \mathrm{C}$ em relação o P1. 
As amostras referentes a cada período de armazenamento e de envelhecimento foram analisadas utilizando-se cinco pares de primers RAPD. De acordo com a figura 3.10, foram formados os seguintes três grupos:

- O primeiro formado pelas amostras P2. 0 h, P3.0 h, P2.48 h e P1.96 h;

- O segundo pelas amostras P1. 0 h e P1.48 h; e

- O último pelas amostras P3. 48 h, P2.96 h e P3.96 h.

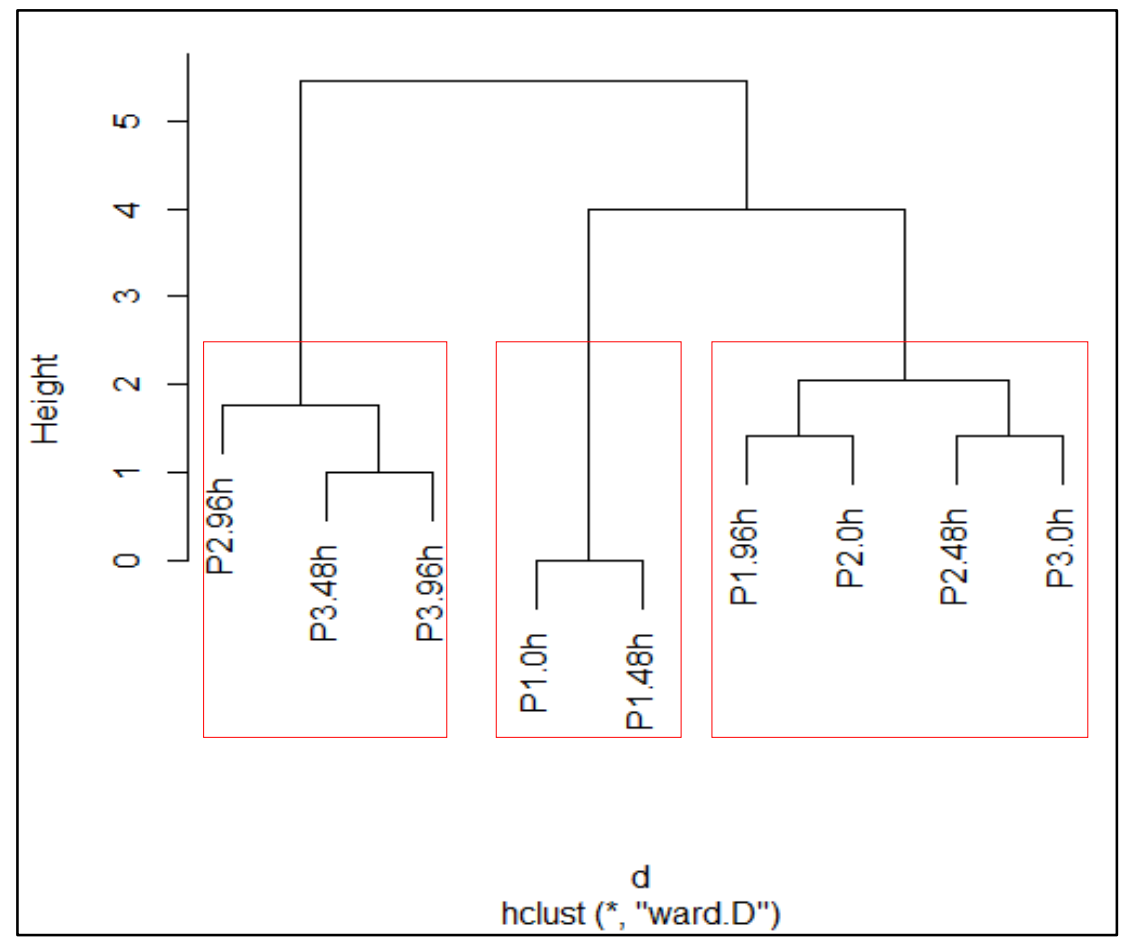

Figura 3.10. Análise de cluster para as amostras de cevada envelhecidas por três diferentes tempos e com três períodos de armazenamento a $10^{\circ} \mathrm{C}$.

Portanto, apesar da análise fisiológica das sementes não indicar grande variação entre os períodos de armazenamento, a análise de agrupamento, com base nos dados de RAPD demonstrou variação entre as amostras. Apesar de na literatura haver dados mostrando que o armazenamento em longo prazo pode gerar mudanças hereditárias (Chwedorzewska et al., 2006), a variação observada na cevada pode não ser devida ao envelhecimento. Pois, todos os tempos de envelhecimento foram distribuídos, praticamente, em todos os clusters formados. Isso pode ser devido ao fato de que as alterações no DNA causadas pelo envelhecimento são aleatórias (Vijg e Suh, 2013) e por isso não há uma relação entre tempo de envelhecimento e a similaridade entre as amostras. Por exemplo, as amostras P1. $96 \mathrm{~h}$ e P2.0 h apresentam 
similaridade muito alta e isso pode ser devido ao fato dos locos amostrados não serem nas regiões genômicas dessas amostras nas quais diferenças surgiram.

As amostras dos três períodos de armazenamento foram distribuídas nos três clusters. Isso pode ter sido devido aos seguintes fatores:

a) $\mathrm{O}$ armazenamento a $10^{\circ} \mathrm{C}$ tem levado a novas alterações que foram detectadas pelo marcador;

b) A quantidade e as variações acumuladas não terem sido refletidas nos locos analisados e

c) As variações dentro do mesmo tempo de armazenamento, por serem aleatórias, acabam gerando subpopulações dentro do mesmo tempo de envelhecimento, que são refletidas no dendograma acima.

Portanto, os dados de RAPD em raízes de cevada envelhecida por diferentes tempos não foram conclusivos são com relação à manutenção da instabilidade entre os períodos de armazenamento.

\subsubsection{Avaliação da degradação do DNA por PCR quantitativo (qPCR)}

Em função dos resultados pouco informativos obtidos em gel de agarose, foi avaliada degradação de DNA por meio de qPCR. A utilização do qPCR para avaliação de degradação parte da ideia que amostras com concentrações diferentes de DNA atingiriam thresholds em números de ciclos diferentes e que evidências obtidas nesse estudo e em estudos prévios demonstram que sementes em diferentes níveis de degradação diferem no grau de deterioração de seus DNAs.

Para testar essa hipótese, a degradação do DNA foi avaliada pela comparação dos CTs obtidos para os sete tempos de envelhecimento para três fragmentos de tamanhos diferentes (86 pb, 193pb, 491pb). Também foram avaliados como controles positivos DNAs obtidos por aquecimento por $0,2,5,10$ e 30 minutos a $95^{\circ} \mathrm{C}$ em banho maria.

Os CTs obtidos, utilizando-se os DNAs das amostras dos tratamentos de envelhecimento acelerado $(0,6,12,24,48,72$ e $96 \mathrm{~h})$ com os primers do fragmento de $86 \mathrm{pb}$, ficaram próximos, tendo média de $22( \pm 0,4)$ a $24( \pm 0,6)$ ciclos para todas as amostras (Figura 3.11a). Os CTs obtidos para as amostras aquecidas a $95^{\circ} \mathrm{C}$ e o fragmento de $86 \mathrm{pb}$ tiveram comportamento parecido, apresentando CTs entre $24( \pm 0,3)$ a $25( \pm 0,7)$ ciclos e nenhuma das amostras se diferenciou do controle (Tabela 3.4 e Figura 3.11d). Portanto, de forma geral, o 
fragmente de $86 \mathrm{pb}$ apresentou pequena variação entre os CTs, não sendo informativo para esse tipo de análise, como mostra os diagramas de dispersão na Figura 3.11.

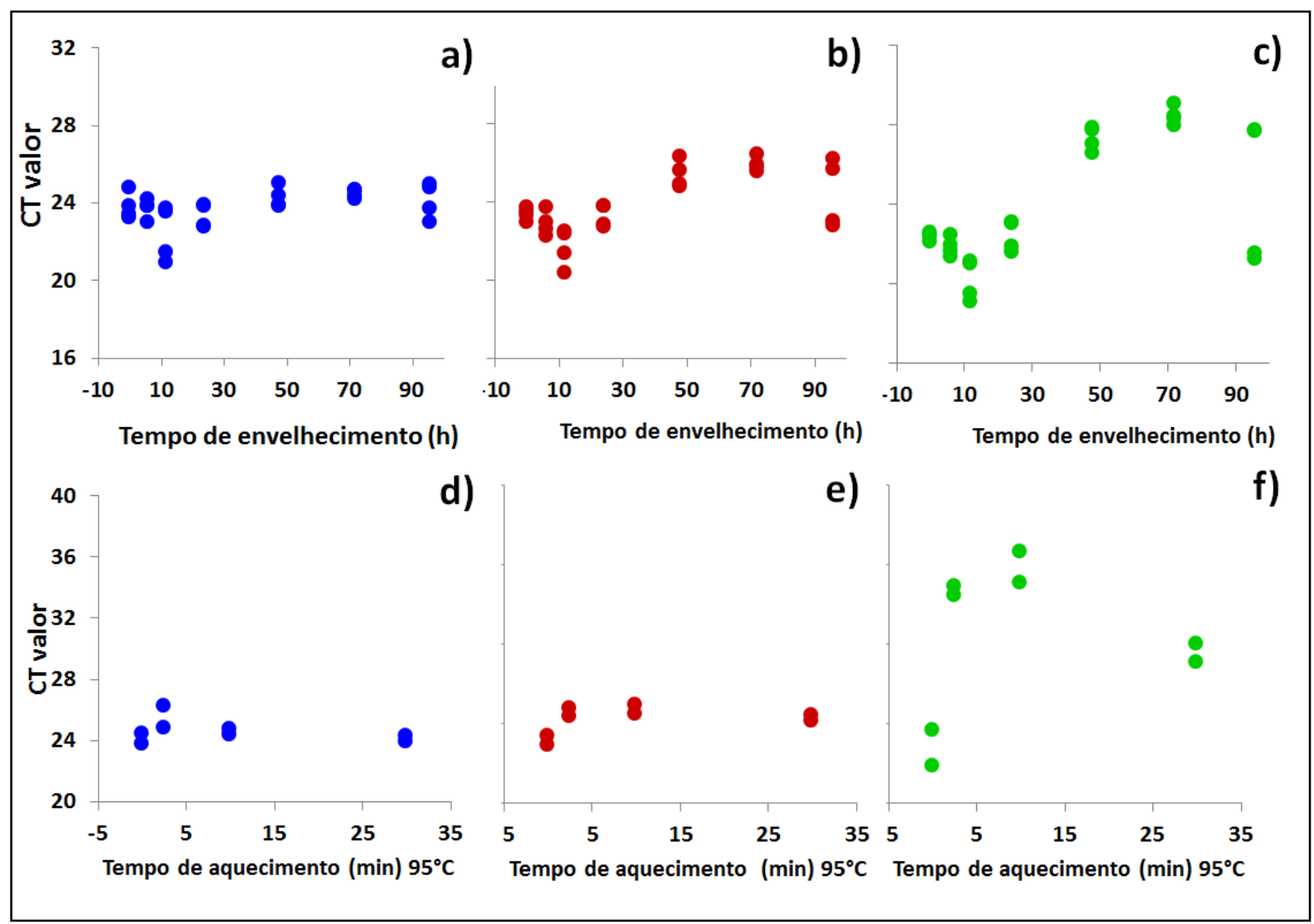

Figura 3.11. Dispersão dos CTs entre as amostras avaliadas para cada primer com fragmentos de diferentes tamanhos. Azul: fragmento de 86 pb. Vermelho: fragmento de 193 pb. Verde: fragmento com $491 \mathrm{pb}$. Letras a), b) e c) são as amostras envelhecidas artificialmente. As letras d), e) e f) são as amostras aquecidas a $95^{\circ} \mathrm{C}$ por 0 a $30 \mathrm{~min}$ (controle positivo de degradação).

Tabela 3.4. Variação média, seguida de desvio padrão, nos CTs das amostras de DNA aquecido a $95^{\circ} \mathrm{C}$ por quatro diferentes tempos para cada comprimento de fragmentos.

\begin{tabular}{cccc}
\hline Tempo de & \multicolumn{3}{c}{ Tamanho do fragmento / CT (Cycle threshold $)$} \\
\cline { 2 - 4 } aquecimento & $86 \mathrm{pb}$ & $193 \mathrm{pb}$ & $491 \mathrm{pb}$ \\
$95^{\circ} \mathrm{C}$ & $24,1 \pm 0,3^{\mathrm{ab}}$ & $23,9 \pm 0,3^{\mathrm{a}}$ & $23,4 \pm 1,1^{\mathrm{a}}$ \\
\hline $0 \mathrm{~min}$ & $25,7 \pm 0,3^{\mathrm{ab}}$ & $33,4 \pm 0,3^{\mathrm{b}}$ \\
$2,5 \mathrm{~min}$ & $25,5 \pm 0,7^{\mathrm{a}}$ & $25,9 \pm 0,3^{\mathrm{b}}$ & $34,8 \pm 1,0^{\mathrm{c}}$ \\
$10 \mathrm{~min}$ & $24,6 \pm 0,2^{\mathrm{ab}}$ & $25,3 \pm 0,2^{\mathrm{ab}}$ & $29,4 \pm 0,6^{\mathrm{d}}$ \\
30 min & $24,1 \pm 0,2^{\mathrm{b}}$ &
\end{tabular}

Médias seguidas por mesma letra em uma mesma coluna não diferem de acordo com o teste de Kruskal-Wallis $(\alpha<0.05)$. 
O fragmento de 193 pb permitiu uma melhor separação entre as amostras mais envelhecidas por meio do número de CTs, como pode ser observado na Figura 3.11b. Os CTs variaram em média entre $22( \pm 0,8)$ a $23( \pm 0,2)$ ciclos para os quatro primeiros tempos de envelhecimento e entre $24( \pm 1,5)$ a $26( \pm 0,2)$ ciclos para os tempos entre 48 à 96 h. Para esse mesmo fragmento, os CTs das amostras do controle positivo variaram em média entre 24 $( \pm 0,3)$ a $26( \pm 0,3)$ ciclos, apresentando uma variação maior entre os CTs em relação ao fragmento de $86 \mathrm{pb}$ (Figura 3.11). Entretanto, diferença significativa em relação ao controle somente foi observada para a amostra de 10 minutos de aquecimento (Tabela 3.4 e Figura 3.11e). O fragmento de $193 \mathrm{pb}$ foi mais informativo que o de $86 \mathrm{pb}$ para a análise de degradação do DNA, tanto para as amostras envelhecidas artificialmente como para as amostras de DNA aquecido a $95^{\circ} \mathrm{C}$, apresentando uma maior separação dos tempos de CTs, como mostram as Figuras 3.11 e 3.12.

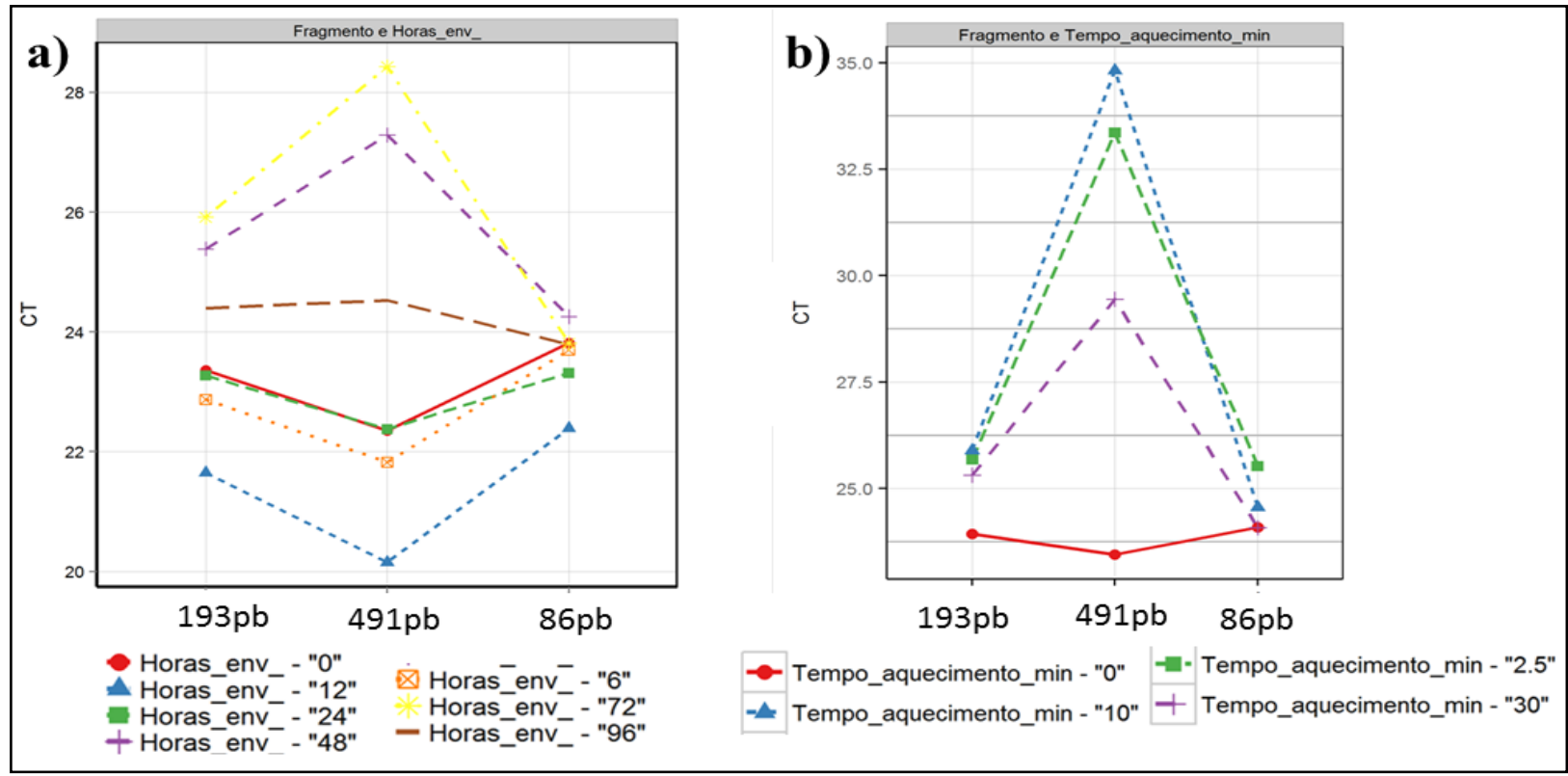

Figura 3.12. Interação entre o tratamento de deterioração do DNA e o comprimento do par de primer sobre os CTs: a) Envelhecimento acelerado e b) DNA aquecido em banho maria a $95^{\circ} \mathrm{C}$.

O fragmento de maior comprimento (491pb) foi o que destacou mais claramente as amostras, com base no número de ciclos (Figura 3.11c e 3.12). Nos quatro primeiros tempos de envelhecimento, os CTs variaram em média entre $20( \pm 0,9)$ a $22( \pm 0,7)$ ciclos e entre 24 $( \pm 3,2)$ a $28( \pm 0,4)$ ciclos para os tempos de 48 a 96 h de envelhecimento acelerado. Para a amostra controle positiva, os tempos variaram entre $23( \pm 1,1)$ a $35( \pm 1,0)$ ciclos para o 
fragmento $491 \mathrm{pb}$, sendo que com esse fragmento foi possível diferenciar significativamente as quatro amostras aquecidas a $95^{\circ} \mathrm{C}$ por diferentes tempos entre si (Tabela 3.4) e isolar a amostra controle (0 min) das demais (Figura 3.11f).

De forma geral os valores de CT apresentaram uma correlação inversamente proporcional com a germinação das sementes, ou seja, conforme menor a taxa de germinação das sementes maior os valores de CT, como mostra a Figura 3.13.

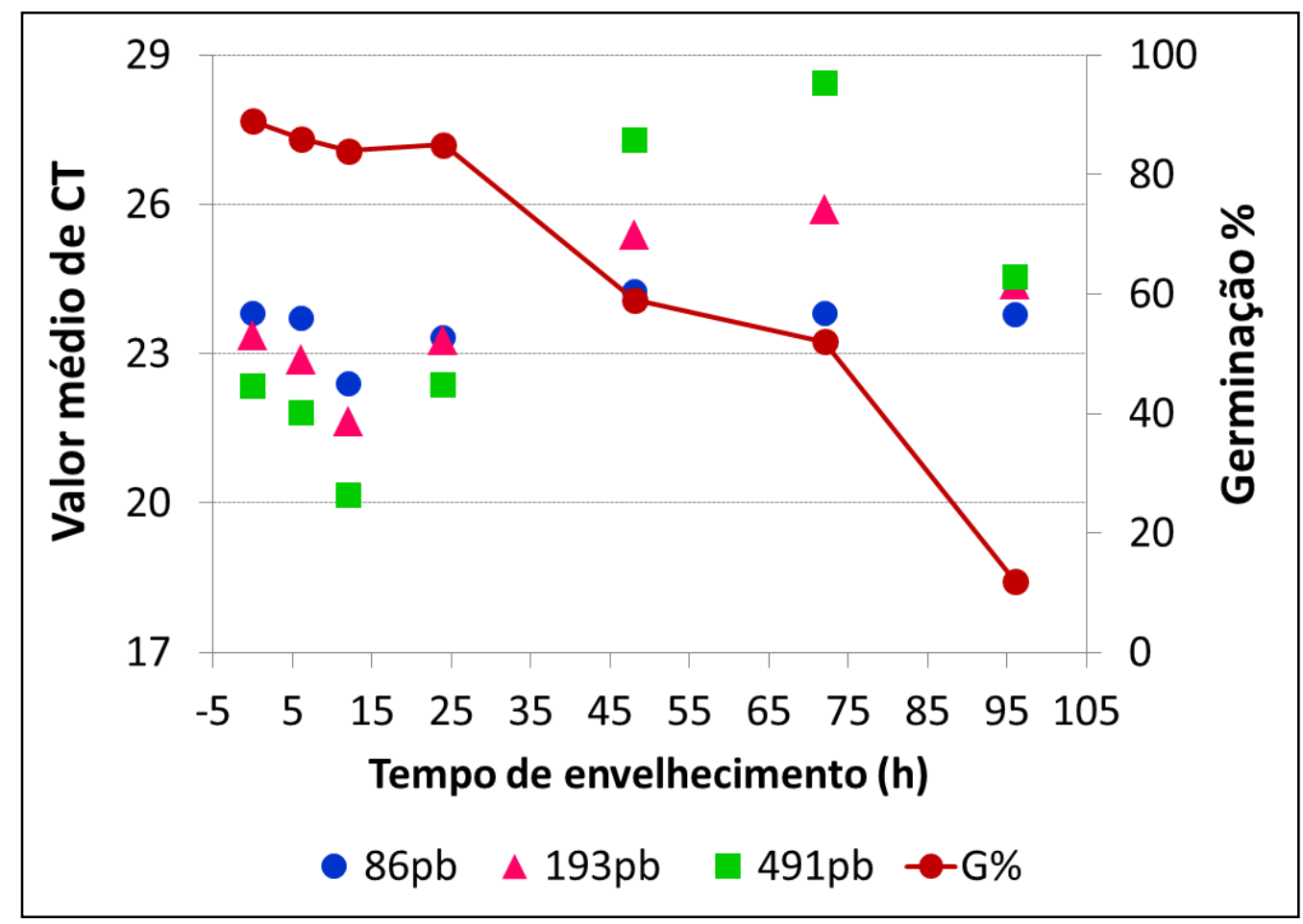

Figura 3.13. Relação entre a taxa de germinação das sementes e os valores de CT para os diferentes lotes de sementes e diferentes comprimentos de fragmentos avaliados. Observa-se uma correlação inversamente proporcional entre as duas variáveis - germinação e valor de CT.

A caracterização do nível de degradação obtida por meio de qPCR indica que é possível avaliar a degradação de DNA através da comparação dos CTs, pois a degradação reduz a quantidade de template disponível, aumentando o CT. Uma única lesão ao DNA é suficiente para bloquear a progressão da polimerase, resultando e uma redução na amplificação do template (Sikorsky et al., 2004).

A diferenciação entre os lotes aumentou à medida que os tamanhos dos fragmentos utilizados no qPCR foram aumentados. Murray et al. (2009), que desenvolveram os primers utilizados nesse estudo, observaram o mesmo padrão em DNA de soja extraídos de produtos 
alimentícios a base de soja e em DNA obtidos a partir de produtos a base de milho (Murray et al., 2007). A explicação para variação observada, analisando-se a mesma região do genoma de soja, são as diferenças entre os tamanhos dos fragmentos avaliados, pois quanto maior o fragmento maior a probabilidade de esse ser rompido, reduzindo a quantidade de molde disponível para amplificação, e, assim, aumentando o CT. Fragmentos menores foram testados porque, segundo a literatura, esses apresentam melhores resultados em qPCR (Bustin e Nolan, 2009), isto é, maior eficiência na amplificação.

Como podem ser observados nas Figuras 3.11 e 3.12, os CTs obtidos com DNAs de algumas amostras com $96 \mathrm{~h}$ de envelhecimento e 30 minutos de aquecimento tiveram valores próximos aos CTs das amostras menos deterioradas. Isso foi observado com os primers dos fragmentos de $491 \mathrm{pb}$ e 193pb, mas nesse último em menor escala. Uma explicação para essa queda do CT em algumas amostras deterioradas é quantificação por fluorímetro, pois este não é hábil para quantificação de DNA degradado (Sedlackova et al., 2013). Por outro lado, apesar desse resultado, a quantificação por fluorímetro foi, entre os métodos de quantificação disponíveis para este estudo, a mais adequada. Assim, a quantidade de DNA na amostra 96 h e 30 min deve ter sido maior do que a das demais amostras e por isso o número de ciclos foi mais baixo. Uma sugestão para a solução desse problema seria a quantificação por qPCR através de uma curva de calibração com amostras com alto grau de integridade e utilizando na extração do DNA, a mesma quantidade de matéria bruta para todas as amostras.

Os dados obtidos com os três pares de primers foram analisados conjuntamente utilizando-se análise de agrupamento (Figura 3.14a). Os dados demonstram que a similaridade entre as amostras diminuem de acordo com o tempo de envelhecimento, isto é, a quantidade de DNA íntegro disponível para a amplificação, no geral, é reduzida em função do envelhecimento, sendo exceções as amostras $12 \mathrm{~h}$ e $96 \mathrm{~h}$. Dentro do grupo das amostras menos envelhecidas, a amostra $12 \mathrm{~h}$ ficou mais isolada, pois apresentou os CTs mais baixos entre todos os tempos de envelhecimento avaliados, como pode ser observado também na Figura 3.11. Dentro do grupo das amostras mais envelhecidas, a amostra $96 \mathrm{~h}$ ficou mais próxima do grupo menos envelhecido $(0,6,12$ e $24 \mathrm{~h})$ do que as amostras $48 \mathrm{~h}$ e $72 \mathrm{~h}$, o que não era esperado. Porém, a análise de agrupamento mostrou que a avaliação da integridade das sementes por qPCR foi satisfatória, pois separou as sementes envelhecidas de 0 a $24 \mathrm{~h}$ das sementes envelhecidas por 48 a $72 \mathrm{~h}$.

O resultado das amostras do controle positivo de degradação, obtidas por meio de aquecimento do DNA, é apresentado na Figura 3.14b. Dois grupos foram observados, sendo um formado pela amostra controle e o outro pelas demais $(2,5,10$ e 30 min). A relação entre 
as amostras foi como esperado, isto é, a distância entre elas aumentou à medida que o tempo de aquecimento aumentou. $\mathrm{O}$ aumento no tempo de aquecimento reduziu o DNA íntegro e aumentou os CTs, com exceção da amostra de $30 \mathrm{~min}$, que ficou mais próxima do controle, o que já havia sido observado nas Figuras 3.11 e 3.12. Entretanto, fica claro o potencial da técnica de qPCR para a avaliação da deterioração do DNA, apesar dos resultados não esperados obtidos com 12 h e 96 h. Como mencionado anteriormente, nenhum dos métodos utilizados na quantificação foi eficaz para DNA degradado e, provavelmente, a qualidade e consequentemente a quantificação do mesmo foi responsável pela aproximação das amostras mais deterioradas às mais íntegras.

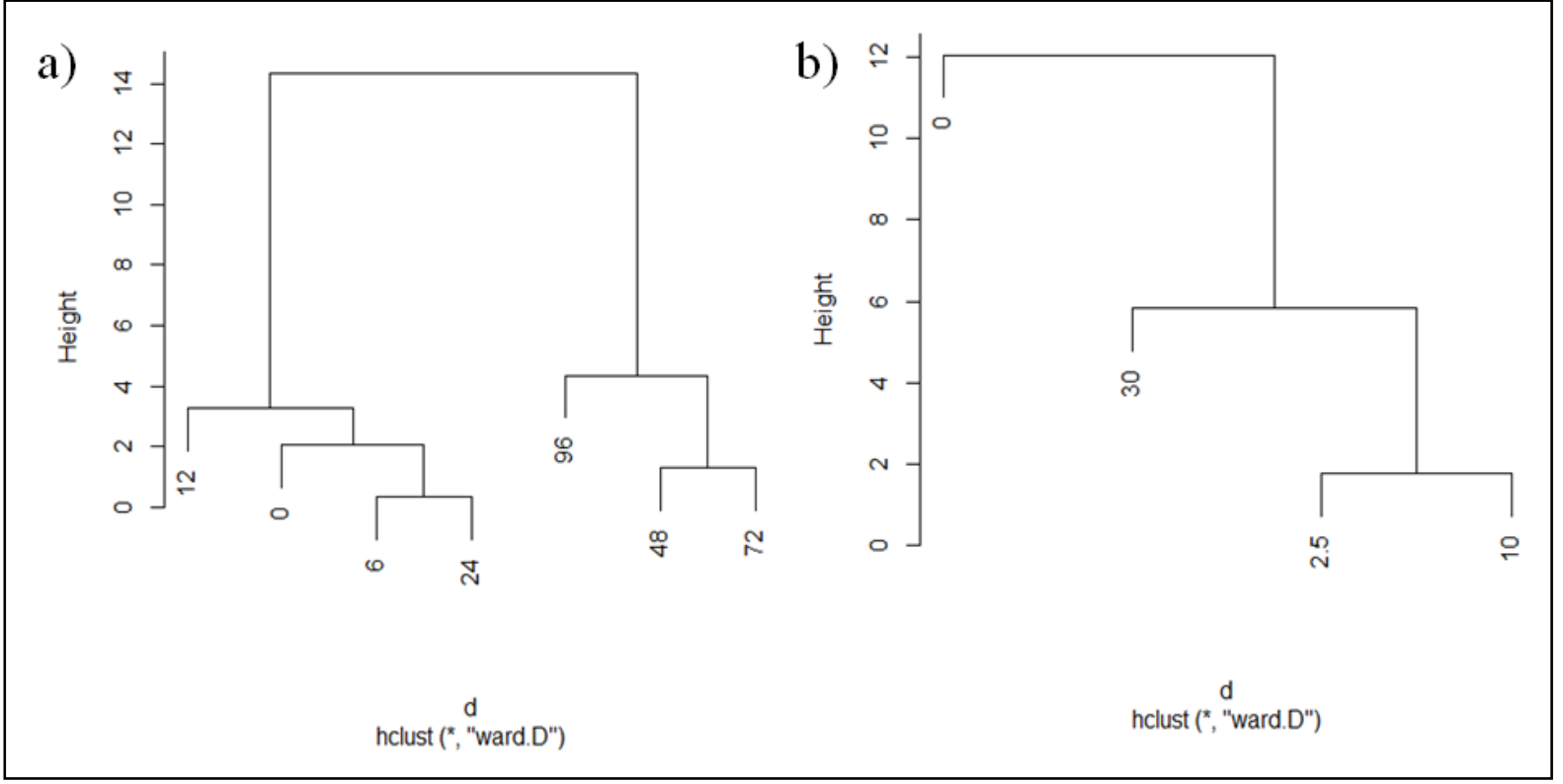

Figura 3.14. Análise de agrupamento das amostras estudadas com base nos CTs obtidos para todos os comprimentos de fragmentos avaliados: a) agrupamento das amostras envelhecidas artificialmente por sete diferentes tempos (h) e b) agrupamento das amostras de DNA aquecido a $95^{\circ} \mathrm{C}$ por quatro tempos diferentes $(\mathrm{min})$.

Além da mensuração da integridade do DNA em sementes durante o envelhecimento, o qPCR poderia também auxiliar na avaliação do reparo do DNA, avaliando-se o DNA extraído das sementes em diferentes tempos de embebição. É fato que o qPCR tem sido utilizado com sucesso para quantificar o dano e o reparo do DNA em diferentes tipos de células e tecidos após exposição a diferentes agentes genotóxicos (Santos, 2006). Wang et al. (2016) demonstraram isso avaliando o dano e o reparo do DNA de células animais expostas ao peróxido de hidrogênio em diferentes concentrações e observaram que após 4 h de cultivo das células em meio de cultura os danos causados foram totalmente reparados. 


\subsection{CONCLUSÕES}

Dentre todas as metodologias moleculares avaliadas, a qPCR foi a melhor para avaliar a integridade das sementes durante o envelhecimento, pois diferenciou melhor as amostras, foi mais objetiva, além de ser bastante aplicável porque necessita de pouco DNA. Espécies com sementes pequenas e ou com poucas sementes para conservação seriam beneficiadas para essa técnica. Apesar do custo alto da qPCR para um banco de germoplasma, uma forma de fazer com que a técnica seja mais barata seria o uso de primers desenhados em regiões conservadas, os quais poderiam ser utilizados em mais de uma espécie.

\subsection{REFERÊNCIAS}

Adeboye, K. A. et al. (2015). SSR analysis of genetic changes during artificial ageing of rice seeds stored under gene bank management. Plant Breed. Seed Sci. 71: 37 - 45.

Araujo, E. S.; Santos, A. M.; De Biase, R. G. (2003). Uso de RAPD para análise de diversidade genética em arroz. Agronomia, 37 (1): 33 - 37.

Arya, M. et al. (2005). Basic principles of real-time quantitative PCR. Expert. Rev. Mol. Diagn., 5 (2) : 209-219.

Bardakci, F. (2001). Random amplified polymorphic DNA (RAPD) markers. Turkish J. Biol., 25 (2): 185 - 196.

Borges, E. C.; Romanha, A. J.; Diotaiuti, L. (2000). Use of random amplified polymorphic DNA (RAPD) in the populational study of Triatoma brasiliensis Neiva, 1911. Cad. Saúde Pública, 16 (2): S97 - S100.

Bustin, S. A.; Nolan, T. (2009). Analysis of mRNA Expression by Real time PCR. In: Logan, J; Edwards, K. J e Saunders, N.(Ed.). Real-time PCR: Current Technology and Applications. Caister Academic Press, Norfolk - UK, pp 111-135.

Chang, S.; Puryear, J.; Cairney, J. (1993). A simple and efficient method for isolating RNA from pine trees. Plant Mol. Biol. Rep., 11 (2): 113 - 116.

Chen, H. et al. (2013). Transcriptome-Wide Mapping of Pea Seed Ageing Reveals a Pivotal Role for Genes Related to Oxidative Stress and Programmed Cell Death. Plos one, 8 (10): $1-15$.

Chauhan, K. P. S.; Swaminathan, M. S. (1984). Cytogenetical effects of ageing in seeds. Genetica, 64 (2): 69 - 76.

Chwedorzewska, K. J. et al. (2006). Studies on genetic changes in rye samples (Secale cereale L.) maintained in a seed bank. Cell. Mol. Biol. Lett., 11 (3): 338-347.

Dang, P. M.; Chen, C. Y. (2013). Modified method for combined DNA and RNA isolation from peanut and other oil seeds. Mol. Biol. Rep, 40 (2): 1563 - 1568. 
Das, S. S. et al. (2015). Small RNA mediated regulation of seed germination. Front Plant Sci., $6: 1-7$.

Donà, M. et al. (2013). DNA profiling, telomere analysis and antioxidant properties as tools for monitoring ex situ seed longevity. Ann Bot., 111 (5): 987 - 998.

El-Maarouf-Bouteau, H. et al. (2011). DNA alteration and programmed cell death during ageing of sunflower seed. J. Exp. Bot., 62 (14): 5003 - 5011.

Faleiro, F. G. (2007). Marcadores-genético moleculares aplicados a programas de conservação e uso de recursos genéticos. Embrapa, Brasília, 102p.

Faria, J. M. R. et al., (2005). Changes in DNA and microtubules during loss and reestablishment of desiccation tolerance in germinating Medicago truncatula seeds. J. Exp. Bot., 56 (418): p. 2119-2130.

Ferreira, E. M; Grattapaglia, D. (1996). Introdução ao uso de marcadores moleculares em análise genética. Embrapa, Brasília, $3^{\mathrm{a}}$ ed, 220p.

Fu Y-B, Ahmed Z and Diederichsen A. (2015). Towards a better monitoring of seed ageing under ex situ seed conservation. Conserv. Physiol. 3: 1-16.

Garcia, C. (2012). Alterações fisiológicas e bioquímicas em sementes de Araucaria angustifolia (Bertoloni) Otto Kuntze sob condições controladas de armazenamento. 117p. Dissertação (Mestrado em Recursos Genéticos Vegetais), Centro de Ciências Agrárias, Universidade Federal de Santa Catarina, Florianópolis, 2012.

Grivicich, I.; Regner, A.; Rocha, A. B. D. (2007). Morte celular por apoptose. Rev. Bras. Cancerol, 53 (3): 335 - 343.

Imbeaud, S. et al. (2005). Towards standardization of RNA quality assessment using userindependent classifiers of microcapillary electrophoresis traces. Nucl. Acids Res., 33 (6): e56 doi:10.1093/nar/gni054.

Jyoti; Malik, C. P. (2013). Seed Deterioration: A Review. J. Life. Sc. Biotechnol. Pharma. Res., 2 (3): 374-385.

Kranner, I. et al.. (2011). Inter-nucleosomal DNA fragmentation and loss of RNA integrity during seed ageing. Plant Growth Regul., 63 (1): 63-72.

Lupchinski J, E. et al. (2006). A importância da utilização da técnica RAPD para a identificação de dactilogirídeos em tilápias do Nilo (Oreochromis niloticus). Arq. ciên. vet. zool. UNIPAR, 9 (1): 49-57.

Marcos-Filho, J. (1999). Teste de envelhecimento acelerado. In: Krzyanowski, F. C.; Vieira, R. D; França, J. B. (Ed.). Vigor de sementes: conceitos e testes. ABRATES, Londrina,. pp.1-24.

Mornkham, T. et al. (2013). Extractions of high quality RNA from the seeds of Jerusalem Artichoke and other plant species with high levels of starch and lipid. Plants, 2 (2): 302-316. 
Murray, S. R. et al. (2007). Use of Quantitative Real-Time PCR To Estimate Maize Endogenous DNA Degradation after Cooking and Extrusion or in Food Products. J. Agric. Food Chem., 55: 2231-2239.

Murray, S. R. et al. (2009). Quantitative real-time PCR assays to detect DNA degradation in soy-based food products. J. Sci. Food Agr., 89 (7): 1137-1144.

Pavan, M. G.; Monteiro, F. A. (2014). Técnicas moleculares aplicadas à sistemática e ao controle vetorial. In: Galvão, C. (Ed.). Vetores da doença de Chagas no Brasil. SciELO-Sociedade Brasileira de Zoologia, Curitiba, pp. 241-260.

Radha, B. N. et al. (2014). DNA Damage During Seed Ageing. IOSR-JAVS., 7 (1): p. 34 39.

Reuzeau, C.; Cavalié, G. (1997). Changes in RNA and protein metabolism associated with alterations in the germination efficiency of sunflower seeds. Ann Bot., 80 (2): 131137.

Santos, J. H. et al. (2006). Quantitative PCR-Based Measurement of Nuclear and Mitochondrial DNA Damage and Repair in Mammalian Cells. DNA Repair Protocols: Mammalian Systems. Humana Press, New Jersey, pp 183-199.

Sedlackova, T. et al. (2013). Fragmentation of DNA affects the accuracy of the DNA quantitation by the commonly used methods. In: Henderson, D. S (Ed.). Biol. Proced. Online, 15 (5): 1- 8 .

Sikorsky, J. A. et al. (2004). Effect of DNA damage on PCR amplification efficiency with the relative threshold cycle method. BBRC, 323: 823-830.

Vicente, D. et al. (2016). Viability of Ocotea puberula (Rich.) Ness Seeds During Storage. Floresta Ambient., 23 (3): 418-426.

Vijay, D.; et al. (2009). Molecular Marker Analysis of Differentially Aged Seeds of Soybean and Safflower. Plant Mol Biol Rep., 27 (3): 282-291.

Vijg, J.; Suh, Y. (2013). Genome Instability and Aging. Annu. Rev. Physiol., 75 (1): 645668.

Wang, C. S.; Vodking, L. (1994). Extraction of RNA from tissues containing high levels of procyanidins that bind RNA. Plant Mol. Bio. Rep., 12 (2): 132-145.

Wang, G.; et al. (2012). Isolation of high quality RNA from cereal seeds containing high levels of starch. Phytochem. Anal., 23 (2): 159-163.

Wang, W. et al. (2016). Quantification of dna damage by real-time qPCR. In: McKenzie, M. Mitochondrial DNA: Methods and Protocols, Methods in Molecular Biology, Humana Press, New york, pp 27-32.

Zarei, A. et al. (2012). An Effective Protocol for Isolation of High-Quality RNA from Pomegranate Seeds. Asian Australas. J. Plant Sci. Biotechnol., 6 (1): 32-37. 


\section{CAPÍTULO 4. ANORMALIDADES CROMOSSÔMICAS E MITÓTICAS EM AMOSTRAS SOJA E CEVADA ENVELHECIDAS ARTIFICIALMENTE}

\section{RESUMO}

Neste capítulo foram avaliados o índice mitótico (IM) e as anormalidades cromossômicas (ACs) em sementes de soja e cevada durante o envelhecimento. Foram realizadas análises fisiológicas e citogenéticas nas sementes envelhecidas artificialmente por 0 (controle), 48 e $96 \mathrm{~h}$ para as sementes de cevada e de 0 a $96 \mathrm{~h}$ para as sementes de soja. O envelhecimento artificial foi realizado em câmara tipo $\mathrm{BOD}$ a $42{ }^{\circ} \mathrm{C}$. $\mathrm{O}$ índice mitótico se mostrou sensível à deterioração das sementes de soja, variando de $18,9 \%$ a $5,8 \%$ para as sementes de soja e $12,6 \%$ a $6,4 \%$ para as sementes de cevada. O número total de aberrações aumentou com o envelhecimento, em relação ao tratamento controle, variando de 2,0 a 12,7 para soja e entre 3,0 a 8,0 anormalidades para cevada. Os tipos de anormalidades cromossômicas mais frequentes foram: os cromossomos dissociados (soltos) em soja e os micronúcleos $(\mathrm{MN})$ em cevada. $\mathrm{O}$ índice mitótico e o número total de anormalidades cromossômicas foram sensíveis ao envelhecimento das sementes estudadas, entretanto o índice mitótico diferenciou melhor os lotes, pois formou mais grupos diferentes entre os lotes com diferentes estágios de deterioração. Os dados obtidos sugerem que a avaliação do IM e das ACs podem ser utilizadas como ferramenta auxiliar na avaliação da viabilidade de sementes e podem ser um método fácil, rápido e barato para se estimar indiretamente a perda de integridade genética em bancos de germoplasma com grandes coleções.

Palavras-chave: dano ao DNA, envelhecimento, índice mitótico, sementes, viabilidade, variabilidade genética.

\subsection{INTRODUÇÃO}

O período de armazenamento sem perda de viabilidade pode variar dentro e entre espécies, mas mesmo em condições ótimas de armazenamento, em qualquer espécie há uma tendência de perda de viabilidade durante períodos longos de armazenamento, devido ao envelhecimento (Khan et al., 2013).

Com o envelhecimento das sementes ocorre perda de vigor, queda da atividade respiratória, aumento de eletrólitos lixiviados, diminuição da capacidade de dilatação da semente durante a embebição (Parrish e Leopold, 1978). Entre as alterações moleculares durante o envelhecimento de sementes, está o surgimento de anormalidades cromossômicas, a 
mudança no tamanho dos telômeros, o dano e metilação do DNA e a anormal expressão gênica (Fu et al., 2015).

A perda da germinação e da integridade genética estão correlacionadas com as anormalidades cromossômicas (ACs) e com mudanças no índice mitótico (IM) em muitas plantas, incluindo soja e cevada (Murata et al., 1981; Rai et al., 2011; Menezes et al., 2014). A exposição constante do DNA ao estresse oxidativo celular e ambiental resulta em danos que podem interromper o crescimento e resultar em mutagênese ou em morte celular (Waterworth et al., 2016). Os danos genéticos podem se acumular na semente afetando o desenvolvimento saudável do embrião e consequentemente impossibilitando a germinação, por isso é necessário o reparo dos danos durante a fase de embebição para que a germinação seja finalizada com sucesso (Khan et al., 2003; Fu et al., 2015).

O monitoramento do germoplasma durante a conservação e muito importante para garantir a manutenção da alta viabilidade e integridade genética. A viabilidade das sementes é monitorada usando-se o teste de germinação e a integridade tem sido mensurada usando-se diferentes métodos, como marcadores moleculares RAPD, AFLP ou SSR e citogenéticos (Chauhan and Swaminathan, 1984; Chwedorzewska et al., 2006; El-Maarouf-Bouteau et al., 2011; Menezes et al., 2014; Adeboye et al., 2015).

A caracterização citogenética de acessos conservados a longo prazo pode ser um importante aspecto do manejo do germoplasma conservado e pode auxiliar na tomada de decisões relacionadas a regeneração, multiplicação e condições de estocagem. Assim, o objetivo deste estudo foi avaliar a frequência de ACs e o IM como ferramenta auxiliar na manutenção de sementes estocadas.

\subsection{MATERIAL E MÉTODOS}

\subsubsection{Material}

As sementes de soja e cevada utilizadas nas análises citogenéticas foram envelhecidas artificialmente por diferentes tempos, conforme descrito no Capítulo 1. Após o envelhecimento as sementes da cevada e soja BRS Flora foram secas e então armazenadas a $20^{\circ} \mathrm{C}$ até o momento da coleta das raízes. A germinação das sementes para coleta das raízes foi realizada a $25^{\circ} \mathrm{C}$, em papel tipo germitest umedecido com água destilada na proporção de 2,5 $\mathrm{x}$ a massa do papel seco. 


\subsubsection{Métodos}

\subsubsection{Fixação das raízes}

Foram coletadas raízes de 20 - 30 sementes de soja e de 10 - 20 sementes de cevada. Quando preciso, a quantidade de sementes mais envelhecidas (48 a $96 \mathrm{~h}$ de envelhecimento) foi maior do que as demais devido à baixa germinação.

Raízes inteiras foram colhidas no momento que estavam com 1 a $2,0 \mathrm{~cm}$ de comprimento para soja e de 1 a $1,5 \mathrm{~cm}$ para as sementes de cevada (Figura 4.1). O tempo necessário para esses comprimentos de raiz foram de dois a três dias de germinação a $25^{\circ} \mathrm{C}$. Em seguida, as raízes foram fixadas durante $24 \mathrm{~h}$, a $4^{\circ} \mathrm{C}$, em Carnoy (ácido acético : álcool etílico (3: 1, v / v)). Após as 24 h de fixação, as raízes foram colocadas em álcool etílico $70 \%$ e armazenadas a $4{ }^{\circ} \mathrm{C}$ até o momento do preparo das lâminas.

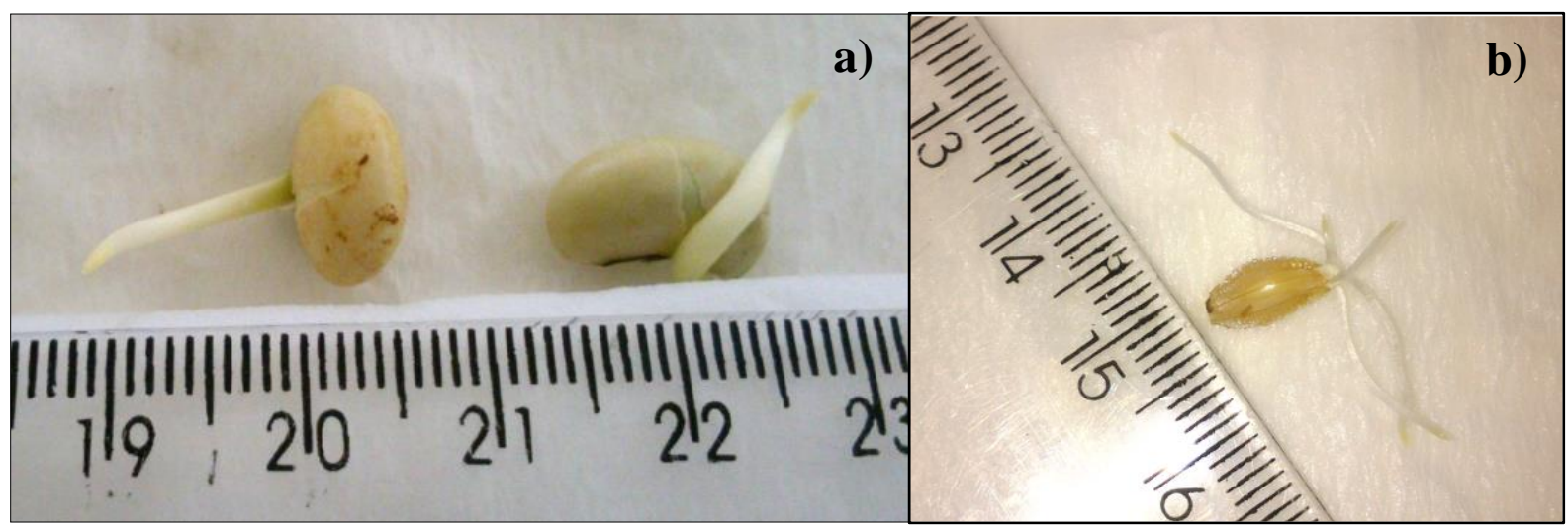

Figura 4.1 Raízes de soja e cevada no momento da coleta: a) raízes de soja com 1,1 cm de comprimento e b) raízes de cevada com 1,3 cm de comprimento. Foto: Renata M. Lopes.

\subsubsection{Preparo das lâminas}

As lâminas foram preparadas adaptando-se a metodologia proposta por Meneguetti et al. (2012). Entre as raízes fixadas, foram coletadas aleatoriamente seis raízes de cada espécie, que foram retiradas do álcool $70 \%$, lavadas em água destilada por um minuto e hidrolisadas em ácido clorídrico $(\mathrm{HCl}) 1 \mathrm{~N}$ por 10 minutos a $60^{\circ} \mathrm{C}$. Após a hidrólise, os tubos com as raízes foram esfriados em água à temperatura ambiente por 20 minutos. Em seguida, as raízes foram lavadas mais uma vez em água destilada, as pontas foram cortadas e preparadas duas lâminas para cada tratamento de envelhecimento. Cada lâmina com três pontas de raízes. As pontas de raízes foram colocadas úmidas nas lâminas, cobertas por lamínulas e realizados 
macerados. As lâminas foram, então, congeladas por um segundo em nitrogênio líquido e a lamínula foi removida rapidamente.

As lâminas foram secas à temperatura ambiente por 30 minutos e então coradas com kit de coloração rápida (Instant Prov), composto pelos seguintes corantes:

- $1^{\circ}$ corante - solução alcoólica de ciclohexadienos a $0,1 \%$;

- $\quad 2^{\circ}$ corante - solução aquosa de azobenzeno sulfônico a $0,1 \%$; e

- $\quad 3^{0}$ corante - solução alcoólica de fenotiazinas a $0,1 \%$.

As lâminas foram imersas nos três corantes, seguindo a sequência acima por 10 vezes, por um segundo cada. Em seguida, as lâminas foram imersas em água destilada por três vezes, por um minuto e secas durante uma hora.

Por fim, foi colocada sobre a lâmina uma gota de verniz vitral incolor Acrilex® (Paiva et al., 2006) e por cima uma lamínula. As lâminas foram secas overnight.

As lâminas foram observadas em microscópio Nikon ${ }^{\circledR}$ Eclipse $\mathrm{C} i$ usando lentes com aumento de 100x.

\subsubsection{Análise estatística}

Foram realizadas quatro repetições com 1000 células, totalizando 4000 células por tratamento de envelhecimento. O índice mitótico (IM\%) foi calculado pela divisão do número total de células em divisão pelo numero total de células analisadas, multiplicando-se por 100. Foram analisadas aberrações cromossômicas dos tipos: cromossomo solto, ponte anafásica, atrasos, micronúcleos e broto nuclear.

Os testes foram realizados de forma aleatória. Os resultados foram expressos com os valores médios e desvio padrão. A normalidade foi avaliada pelo teste de Anderson-Darling e a homogeneidade das variâncias pelo teste de Bartlett, ambos ao nível de significância de $\alpha<$ 0,05. Para as comparações das médias foi utilizado o teste de Tukey para os dados com distribuição normal e Kruskal-Wallis para os dados sem distribuição normal $(\alpha<0,05)$. Todos os testes estatísticos foram realizados em Excel com suplementação do software de estatística ActionStat® (http://www.portalaction.com.br).

\subsection{RESULTADOS E DISCUSSÃO}

O envelhecimento artificial das sementes tem sido utilizado em diferentes estudos (ElMaarouf-Bouteau et al., 2011; Kranner et al., 2011) para simular o envelhecimento natural 
durante a estocagem, aumentando a deterioração e a respiração celular pelo aumento da temperatura e umidade (Jyoti e Malik, 2013; Nagel et al., 2015).

Diferenças significativas foram observadas na porcentagem de plântulas normais das sementes envelhecidas por diferentes tempos. As sementes controle da cevada apresentaram 97\% de germinação, mas a germinação diminuiu para $61 \%$ e 24\% após 48 h e 96 h de envelhecimento, respectivamente (Tabela 4.1). As sementes da Soja BRS Flora tiveram 68\% de germinação na amostra controle e a germinação diminuiu para 11\% e 4\% após 24 e 48h, respectivamente (Tabela 4.1). Já a soja BRS 7980 teve germinação nos primeiros quatro tempos de envelhecimento ( 0 a 24 h) variando entre 85 a $89 \%$, sendo que a germinação diminuiu para 59, 52 e 12\% após 48, 72 e 96 h de envelhecimento respectivamente (Tabela 4.1).

\subsection{1 Índice mitótico}

A divisão celular é prejudicada pelos danos oriundos do envelhecimento, Menezes et al. (2014) observaram diminuição no índice mitótico em lotes de sementes de trigo mais envelhecidos em comparação com lotes controle. Aqui nesse estudo não foi diferente. O IM foi negativamente correlacionado com o tempo de envelhecimento. Para cevada o IM das sementes controle foi de 12,6\%, após 48 h foi de 8,6\% e depois de 96 h de envelhecimento 6,4\% (Tabela 4.1). Para soja cv Flora o IM foi de 12,6\% para o controle, 8,7\% para o tratamento 48 h de envelhecimento e 5,8\% para o de 96 h. Já para soja cv 7980 o controle teve IM de 18,9\%, para os tratamentos com 6 a 12 h de envelhecimento o IM ficou em torno de $16 \%$. Entre os tratamentos $24 \mathrm{~h}$ e $96 \mathrm{~h}$ de envelhecimento o IM variou de 14,2\% diminuindo até 9,5\% (tabela 4.1), no geral para a soja cv 7980, o IM foi capaz de diferenciar em cinco grupos os sete lotes de sementes avaliados e o teste de germinação três grupos. Chauhan e Swaminathan (1984), também observaram redução expressiva no IM de sementes de soja envelhecidas artificialmente por até $42 \mathrm{~h}$.

\subsubsection{Frequência de anormalidades cromossômicas}

O envelhecimento das sementes está associado ao aumento da incidência de anormalidades cromossômicas e mesmo sementes com altas taxas de germinação apresentam algum nível de dano no genoma (Waterworth et al., 2016). Diferentes tipos de ACs foram observadas nas raízes meristemáticas de cevada e soja nas amostras controles e envelhecidas: atraso cromossômico, cromossomo solto, ponte anafásica, micronúcleos $(\mathrm{MN})$ e broto nuclear 
(Figuras 4.2 e 4.3). Nas raízes da cevada os MN foram o tipo de AC mais frequente, seguidos pelo tipo cromossomos soltos (Tabela 4.1). Já nas amostras de soja os cromossomos soltos foram as ACs mais frequentes seguidos pelos brotos nucleares (Tabela 4.1).

No geral, as ACs aumentaram com o tempo de envelhecimento (Tabela 1). Nas amostras de cevada as ACs aumentaram 50\% após 48 h e 167\% após 96 h de envelhecimento em relação ao controle (0 h). Murata et al. (1981) observaram aumento de $79 \%$ na frequência de anormalidades em anáfases de raízes de cevada e redução de 14 \% na germinação de sementes de cevada armazenadas a $21{ }^{\circ} \mathrm{C}$ e $12 \%$ de umidade relativa por um ano. Akhter et al. (1992) também observaram redução na germinação em sementes de cevada armazenadas de 1 a 10 anos em dessecador, livre de umidade. Estes autores obtiveram redução de $76 \%$ na germinação das sementes com 10 anos de armazenamento e aumento de 583\% na frequência de ACs. A correlação entre os dados de Murata et al. (1981) e de Akhter et al. (1992) e os obtidos nesse estudo não é possível, devido ao fato de que a umidade relativa mais alta, aumenta o envelhecimento e o número de ACs (Dourado e Roberts, 1984; El-MaaroufBouteau et al., 2011). Entretanto, os dados sugerem que as ACs podem ser usadas para o estudo da integridade de sementes de cevada envelhecidas artificialmente ou naturalmente. 
Tabela 4.1. Valores médios seguidos do desvio padrão da análise fisiológica e citogenética e de soja e cevada após envelhecimento acelerado.

\begin{tabular}{|c|c|c|c|c|c|c|c|c|}
\hline $\begin{array}{c}\text { Tempo de } \\
\text { envelhecimento/ } \\
\mathrm{cv} \\
\end{array}$ & $\mathrm{G} \%$ & $\mathrm{IM}$ & AT & $\mathrm{MN}$ & Broto & $\begin{array}{c}\text { Cromossomo } \\
\text { solto }\end{array}$ & Atraso & Ponte \\
\hline Cevada Caué 0 h & $97 \pm 3,0^{\mathrm{a}}$ & $12,6 \pm 0,3^{\mathrm{a}}$ & $3,0 \pm 0,7^{\mathrm{a}}$ & $1,3 \pm 0,5^{\mathrm{a}}$ & $0,0^{\mathrm{a}}$ & $1,3 \pm 0,9^{a}$ & $0,0 \mathrm{a}$ & $0,3 \pm 0,5^{a}$ \\
\hline Cevada Caué 48 h & $61 \pm 3,6^{b}$ & $8,6 \pm 0,8^{b}$ & $4,5 \pm 1,7^{\mathrm{a}}$ & $1,7 \pm 1,2^{a b}$ & $0,3 \pm 0,5^{\mathrm{ab}}$ & $1,7 \pm 1,7^{\mathrm{a}}$ & $0,3 \pm 0,5^{a b}$ & $0,0^{\mathrm{a}}$ \\
\hline Cevada Caué 96 h & $26 \pm 3,7^{\mathrm{c}}$ & $6,4 \pm 0,3^{\mathrm{c}}$ & $8,0 \pm 0,7^{b}$ & $3,7 \pm 1,2^{b}$ & $2,0 \pm 0,4^{b}$ & $1,3 \pm 1,2^{\mathrm{a}}$ & $1,0 \pm 0,0^{b}$ & $0,3 \pm 0,5^{\mathrm{a}}$ \\
\hline Soja Flora $0 \mathrm{~h}$ & $68 \pm 5,0^{a}$ & $12,6 \pm 2,0^{\mathrm{a}}$ & $2,0 \pm 0,6^{\mathrm{a}}$ & $0,0^{\mathrm{a}}$ & $0,0^{\mathrm{a}}$ & $2,0 \pm 0,8^{\mathrm{a}}$ & $0,0^{\mathrm{a}}$ & $0,0^{\mathrm{a}}$ \\
\hline Soja Flora 24 h & $11 \pm 1,0^{b}$ & $8,7 \pm 2,2^{a}$ & $4,4 \pm 2,00^{a b}$ & $0,7 \pm 0,5^{\mathrm{a}}$ & $0,0^{\mathrm{a}}$ & $2,3 \pm 2,0^{\mathrm{a}}$ & $0,3 \pm 0,5^{a b}$ & $0,0^{\text {a }}$ \\
\hline Soja Flora 48 h & $4 \pm 3,2^{c}$ & $5,8 \pm 0,2^{b}$ & $3,6 \pm 0,5^{b}$ & $0,3 \pm 0,5^{\mathrm{a}}$ & $0,7 \pm 0,5^{\mathrm{b}}$ & $2,3 \pm 0,5^{\mathrm{a}}$ & $0,7 \pm 0,5^{b}$ & $0,0^{\mathrm{a}}$ \\
\hline Soja $79800 \mathrm{~h}$ & $89 \pm 3,6^{a}$ & $18,9 \pm 0,8^{a}$ & $2,0 \pm 0,8^{a}$ & $0,0^{\mathrm{a}}$ & $1,0 \pm 0,8^{a b c}$ & $1,0 \pm 1,4^{\mathrm{a}}$ & $0,0^{\text {a }}$ & $0,0^{\mathrm{a}}$ \\
\hline Soja $79806 \mathrm{~h}$ & $86 \pm 8,6^{a}$ & $16,4 \pm 0,6^{b}$ & $3,7 \pm 0,9^{a b}$ & $0,0^{\mathrm{a}}$ & $1,7 \pm 1,2^{\mathrm{abd}}$ & $1,0 \pm 0,0^{\mathrm{a}}$ & $1,0 \pm 0,8^{a b}$ & $0,0^{\mathrm{a}}$ \\
\hline Soja 798012 h & $87 \pm 3,8^{a}$ & $16,0 \pm 0,6^{b}$ & $3,3 \pm 1,2^{a b}$ & $0,0^{\mathrm{a}}$ & $2,0 \pm 0,0{ }^{\mathrm{ad}}$ & $1,0 \pm 0,8^{\mathrm{a}}$ & $0,0^{\mathrm{a}}$ & $0,3 \pm 0,5^{a b}$ \\
\hline Soja 798024 h & $85 \pm 5,0^{a}$ & $14,2 \pm 0,2^{\mathrm{c}}$ & $2,7 \pm 1,2^{\mathrm{a}}$ & $0,0^{\mathrm{a}}$ & $0,3 \pm 0,5^{\mathrm{bc}}$ & $1,7 \pm 0,9^{a b}$ & $0,7 \pm 0,5^{\mathrm{ab}}$ & $0,0^{\mathrm{a}}$ \\
\hline Soja 798048 h & $59 \pm 3,8^{b}$ & $13,7 \pm 0,4^{\mathrm{c}}$ & $6,0 \pm 2,2 \mathrm{bc}$ & $0,0^{\mathrm{a}}$ & $0,0^{\mathrm{c}}$ & $5,0 \pm 2,2^{c}$ & $1,0 \pm 0,8 \mathrm{ab}$ & $0,0^{\mathrm{a}}$ \\
\hline Soja 798072 h & $52 \pm 1,7^{b}$ & $12,1 \pm 0,2^{d}$ & $7,7 \pm 1,2^{\mathrm{c}}$ & $0,3 \pm 0,5^{\mathrm{a}}$ & $3,3 \pm 1,2^{d}$ & $3,3 \pm 0,9 \mathrm{bc}$ & $0,3 \pm 0,5^{b}$ & $0,3 \pm 0,5^{\mathrm{ab}}$ \\
\hline Soja 798096 h & $12 \pm 0,9^{c}$ & $9,5 \pm 1,1^{\mathrm{e}}$ & $12,7 \pm 3,4^{\mathrm{c}}$ & $1,3 \pm 0,5^{b}$ & $3,0 \pm 1,6^{\mathrm{ad}}$ & $5,3 \pm 1,7^{\mathrm{c}}$ & $2,3 \pm 1,2^{b}$ & $0,7 \pm 0,5^{b}$ \\
\hline
\end{tabular}

As médias foram obtidas de três repetições e estão seguidas pelo desvio padrão. Médias seguidas por mesma letra em uma mesma coluna e em uma mesma cultivar, não diferem de acordo com o teste de Tukey $(\alpha<0,05)$ para dados da cevada e Kruscal-Wallis $(\alpha<0,05)$ para dados da soja. G\% $=$ germinação. 


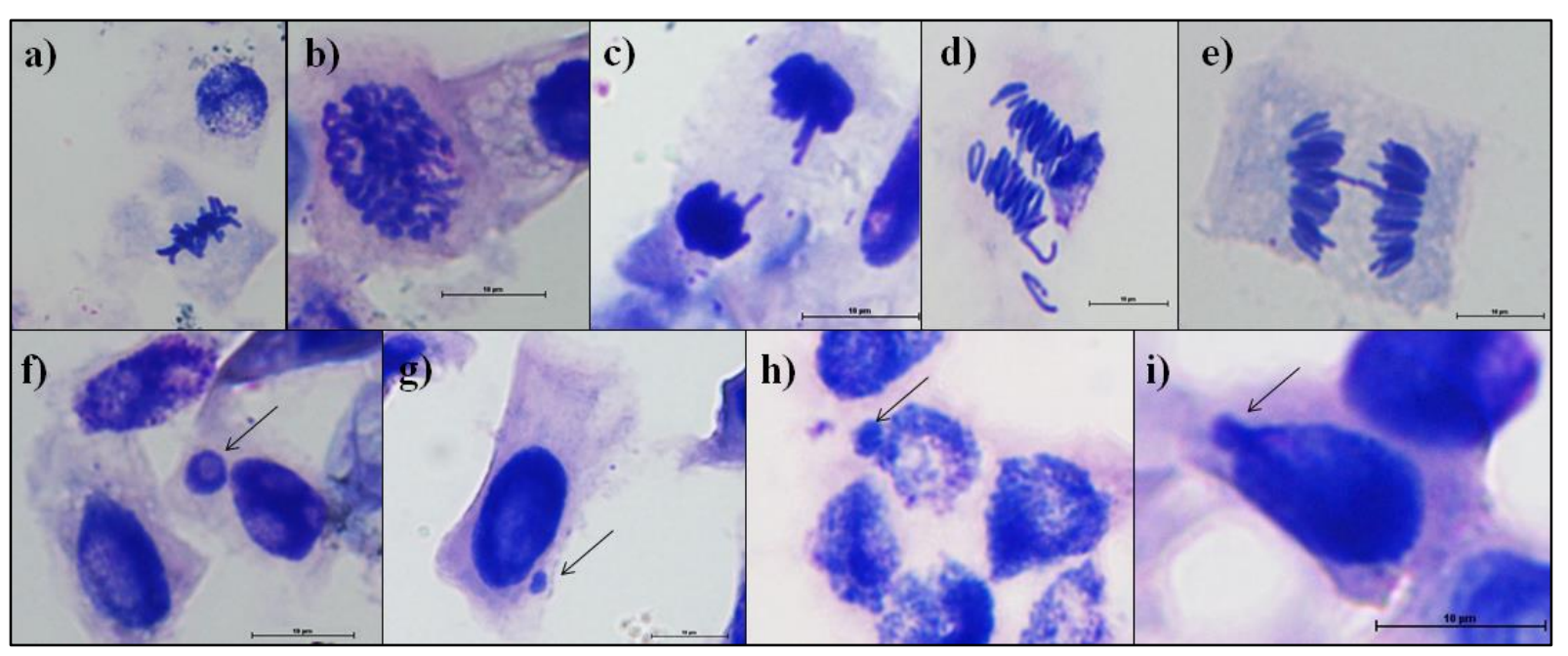

Figure 4.2. Células normais e anormais de raízes de cevada após tratamento de envelhecimento artificial: a) interfase e metáfase regulares, b) prófase regular, c) atraso cromossômico, d) cromossomo solto, e) ponte anafásica, f) e g) micronúcleos, h) e i) broto nuclear. Barra escala $=10 \mu \mathrm{m}$.

De acordo com a Tabela 4.1, observa-se que para as sementes de soja cv Flora, a frequência de cromossomos soltos não mudou entre os tratamentos de envelhecimento, ficando entre 2,0 $\pm 0,8$ a 2,3 $\pm 0,5$. Houve ocorrência de micronúcleos apenas nos tratamentos envelhecidos (24 h e $48 \mathrm{~h}$ ), mas sem diferenças significativas. Os brotos nucleares foram observados apenas no tratamento mais envelhecido (48h). Os atrasos em anáfase e telófase foram mais frequentes na amostra mais envelhecida, diferindo da amostra controle, assim como também os brotos nucleares. Não foi observada a formação de pontes anafásicas em nenhum dos tratamentos para o cv Flora (Tabela 4.1). 


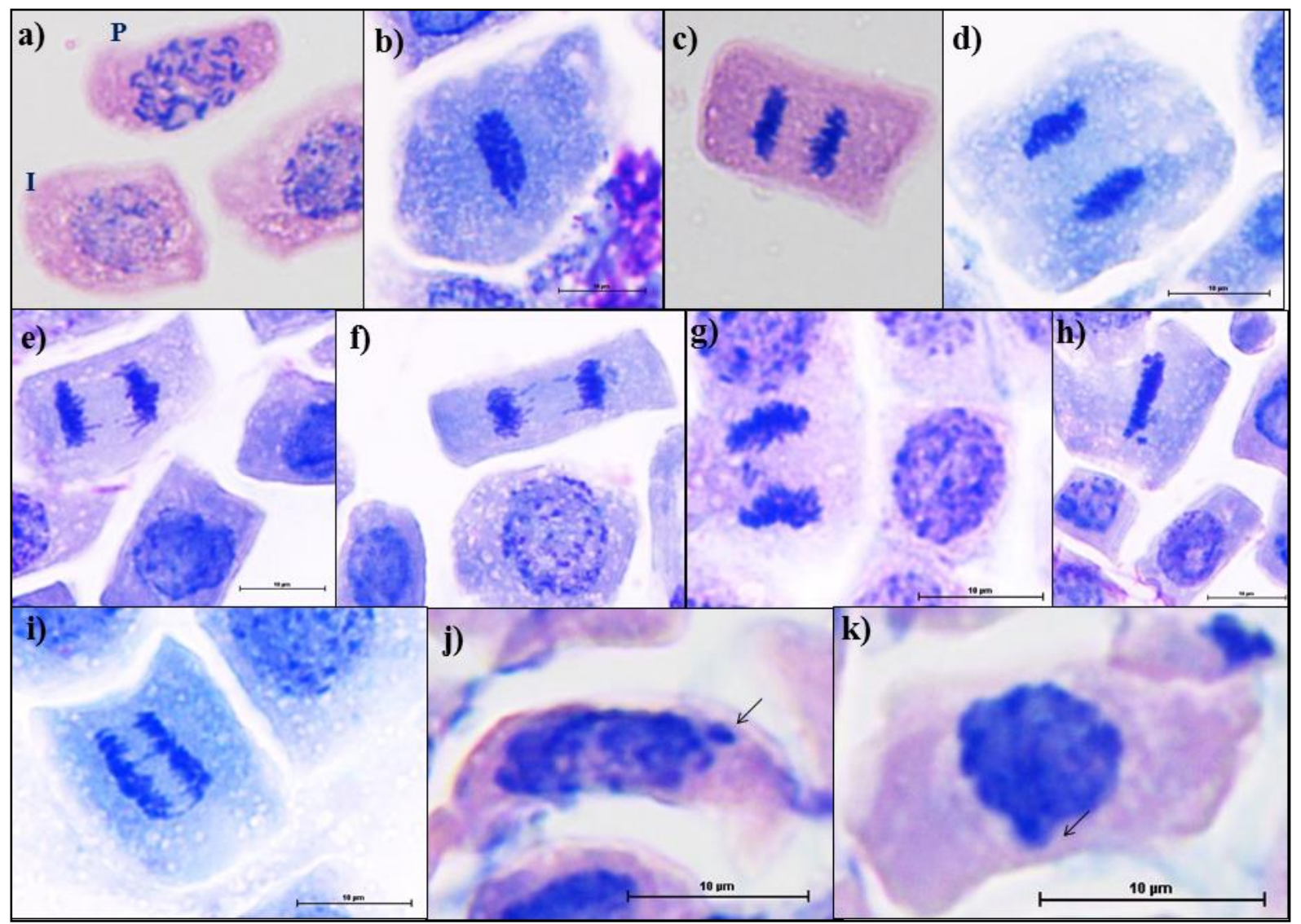

Figura 4.3. Células meristemáticas regulares e anormais de soja após envelhecimento acelerado: a) interfases (I) e prófase (P) regulares, b) metáfase regular, c) anáfase regular, d) telófase regular, e) atraso em anáfase f) atraso e cromossomo solto em telófase, g) e h) cromossomo solto, i) ponte e atraso anafásico, j) micronúcleo e k) broto nuclear. Barra escala $10 \mu \mathrm{m}$.

Para a soja cv 7980 o número total de aberrações também variou entre os tratamentos, de 2,0 ( $\pm 0,8)$ no controle a $12,7( \pm 3,4)$ para a $96 \mathrm{~h}$, sendo que as amostras de $48 \mathrm{~h}$ e $96 \mathrm{~h}$ diferiram significativamente do controle e os quatro primeiros tempos foram iguais entre si (Tabela 4.1). Os cromossomos soltos foram diferentes entre as amostras menos envelhecidas (0-24h) e as amostras mais envelhecidas (48 - $96 \mathrm{~h})$, variando de 1,0 $( \pm 1,4)$ no controle para $5,3$ ( $\pm 1,7)$ na amostra 96h. Já os atrasos em anáfases e telófases diferiram apenas entre o controle e as amostras 72 e 96h, variando de 0,0 a 2,3 ( $\pm 1,2)$ para controle e $96 \mathrm{~h}$, respectivamente. Como pode ser visto na Tabela 4.1, os micronúcleos diferiram apenas na amostra $96 \mathrm{~h}$, apresentando de 0,0 a $1,3( \pm 0,5)$ entre o controle e o tratamento mais envelhecido. As pontes anafásicas apareceram apenas em alguns tratamentos, diferindo apenas para o tratamento $96 \mathrm{~h}$. 
Com o envelhecimento as ACs na soja Flora chegou a aumentar até $120 \%$ em relação à amostra controle, mas com significância estatística apenas para o tratamento 48 h (Tabela 4.1). Já para a soja 7980, até o tratamento 24 h de envelhecimento, as ACs aumentaram de $35 \%$ a $85 \%$ em relação ao controle. Entre os tratamentos 48 h a 96 h, dessa mesma cultivar de soja, as ACs aumentaram de $200 \%$ a $535 \%$ em relação ao controle. Chauhan e Swaminathan (1984), também observaram aumento expressivo na frequência de ACs em soja envelhecida artificialmente $\left(40{ }^{\circ} \mathrm{C}\right.$ e $\left.100 \mathrm{UR}\right)$ por até $48 \mathrm{~h}$, chegando a um aumento de $120 \%$ em relação a amostra controle.

Esse aumento na frequência de ACs após o envelhecimento indica que o sistema de reparo do DNA se torna menos eficiente com o aumento do tempo de envelhecimento, uma vez que as ACs resultam de danos à dupla fita do DNA (Fu et al., 2015). A perda de eficiência do sistema de reparo do DNA foi detectada em sementes de ervilha (Pisum sativum L.) envelhecidas artificialmente $\left(50{ }^{\circ} \mathrm{C}\right.$ e $60 \%$ de UR) por diferentes períodos $(0,25,31$ e 55 dias) (Kranner et al., 2011). Os dados indicam que a avaliação citogenética pode ser usada para avaliar indiretamente o sistema de reparo do DNA, que é muito importante para o entendimento da perda da viabilidade em sementes devido o envelhecimento, como também para a integridade genética de sementes armazenadas.

A avaliação da perda de integridade genética por um método seguro e barato é muito importante para bancos de germoplasma. Como mencionado anteriormente, muitas ACs foram observadas nos resultados deste estudo e essas ACs são causadas por dano a fita dupla do DNA, os quais em eucariotos são reparados por duas vias principais - por recombinação homóloga e por recombinação não homóloga (Sancar et al., 2004). A recombinação não homóloga pode introduzir variabilidade genética, pois como a homologia não é necessária para garantir que as moléculas sejam reincorporadas na correta posição, deleções e duplicações de segmentos cromossômicos (variação no número de cópias) aumentam a probabilidade de alguma mudança (Hastings et al., 2009). A recombinação não homóloga leva a pequenas deleções (1-4 pb) e ocasionalmente a inserção de DNA livre, frequentemente de mitocôndrias ou retrotransposons (Hastings et al., 2009). Assim, a frequência de ACs tem potencial para estimar indiretamente a variação introduzida devido o envelhecimento. 


\subsection{CONCLUSÃO}

O IM foi sensível à deterioração das sementes soja e cevada, distinguindo os lotes de sementes em diferentes estágios de deterioração, inclusive os três primeiros tempos de envelhecimento da soja cv 7980 (6 h a 24 h) em relação ao controle, os quais foram iguais pelo teste de germinação.

A frequência de ACs teve correlação diretamente proporcional com o tempo de envelhecimento, aumentando à medida que aumentou o tempo de envelhecimento.

Os dados indicam que a citogenética pode ser utilizada como ferramenta auxiliar na avaliação da viabilidade de sementes e pode ser um bom meio de se estimar indiretamente a perda de integridade e a queda na eficiência do sistema de reparo do DNA, além de ser um método rápido e barato, o que é muito interessante para bancos de germoplasma com coleções muito grandes.

\subsection{REFERÊNCIAS}

Adeboye K. A. et al. (2015). SSR analysis of genetic changes during artificial ageing of rice seeds stored under gene bank management. Plant Breed. Seed Sci. 71: 37 - 45.

Akhter, F. N. et al. (1992). Aging effect of wheat and barley seeds upon germination mitotic index and chromosomal damage. J. Islamic Acad. Sci., 5 (1): 44-48.

Chauhan, K. P. S.; Swaminathan, M. S. (1984). Cytogenetical effects of ageing in seeds. Genetica, 64 (2): 69 - 76.

Chwedorzewska K. J. et al. (2006). Studies on genetic changes in rye samples (Secale cereale L.) maintained in a seed bank. Cell. Mol. Biol. Lett., 11: 338-347.

Dourado A. M; Roberts E. H. (1984). Chromosome Aberrations Induced during Storage in Barley and Pea Seeds. Ann. Bot. 54: 767-779.

El-Maarouf-Bouteau, H. et al. (2011). DNA alteration and programmed cell death during ageing of sunflower seed. J. Exp. Bot. 62: 5003-5011.

Fu, Y-B; Ahmed, Z ; Diederichsen, A. (2015). Towards a better monitoring of seed ageing under ex situ seed conservation. Conserv. Physiol. 3: 1-16. 
Hastings, P. J. et al. (2009). Mechanisms of change in gene copy number. Nat. Rev. Genet. 10: 551-64.

Jyoti e Malik CP. (2013). Seed deterioration: a review. Int. J. Life. Sc. Biotechnol. Pharma. Res., 2: 374-385.

Khan, M. et al. (2013). Physio-biochemical and Genetic Changes in Stored Pea (Pisum sativum) Seeds. Int J Agric Biol., 15 (5): 951-956.

Khan, M. M. et al. (2003). Effect of Ageing on Viability, Vigour and Chromosomal Damage in Pea (Pisum sativum L.) seeds. Pakistan J. Agri. Sci., 40 (1): 50-54.

Kranner, I; et al. (2011). Inter-nucleosomal DNA fragmentation and loss of RNA integrity during seed ageing. Plant Growth Regul. 63: 63-72.

Meneguetti, D.; et al. (2012). Adaptation of the Micronucleus Technique in Allium Cepa, For Mutagenicity Analysis of the Jamari River Valley, Western Amazon, Brazil. J. Environ. Anal. Toxicol., 2 (2): 1-3.

Menezes V.O; et al. (2014). Cytogenetic analysis of wheat seeds submitted to artificial aging stress. J. Seed Sci., 36: 71-78.

Murata, M; Ross, E. E.; Tsuchiya, T. (1981). Chromosome damage induced by artificial seed aging in barley. I.Germinability and frequency of aberrant anaphases at first mitosis. $\mathbf{J}$ Genet Cytol, 23:267-280.

Nagel, M.; et al. (2015). Genome-wide association mapping and biochemical markers reveal that seed ageing and longevity are intricately affected by genetic background and developmental and environmental conditions in barley. Plant Cell Environ, 38: 10111022 .

Paiva, J. G. A; et al. (2006). Verniz vitral incolor 500®: uma alternativa de meio de montagem economicamente viável. Acta Bot. Bras., 20 (2): 257-264.

Parrish, D. J; Leopold, A. C. (1978). On the mechanism of aging in soybean seeds. Plant Physiol. 61 (3): 365-368. 
Rai, P. K.; Kumar, G.; Singh, K. (2011). Influence of packaging material and storage time on seed germination and chromosome biology of inbred line of maize (Zea mays L.). J. Agric.Technol. 7: 1765-1774.

Sancar, A.; et al.(2004). Molecular Mechanisms of Mammalian DNA Repair and the DNA Damage Checkpoints. Annu. Rev. Biochem., 73: 39-85.

Waterworth, W. M.; et al. (2016). DNA damage checkpoint kinase ATM regulates germination and maintains genome stability in seeds. PNAS, 113 (34): 9647-9652. 


\section{CONCLUSÃO GERAL}

Apesar de ser uma metodologia barata, a avaliação da integridade e eficiência do sistema de reparo do DNA, como também a avaliação da integridade do RNA, ambos por gel de agarose corado com brometo de etídio, não foram auxiliares na avaliação da integridade das sementes, tanto para as sementes de soja como para as sementes de cevada. Essa metodologia teve pouca reprodutibilidade e necessitou de uma grande quantidade de DNA.

O RAPD, apesar das limitações da técnica como a baixa reprodutibilidade, foi auxiliar na avaliação das sementes de soja, pois diferenciou os lotes de sementes e ainda possibilitou avaliar o sistema de reparo do DNA nas sementes envelhecidas. Além disso, foi uma técnica que necessitou de pouco DNA e é uma técnica barata. Uma recomendação para diminuir a baixa reprodutibilidade da técnica seria aumentar o número de repetições.

Dentre todas as metodologias moleculares avaliadas o qPCR foi a melhor para avaliar a integridade das sementes de soja, pois foi capaz de diferenciar os lotes das sementes mais envelhecidas das menos envelhecidas, foi mais objetiva do que as demais metodologias e necessitou de uma pequena quantidade de DNA, apenas $6 \mathrm{ng}$. O que é muito importante para um banco de germoplasma que nem sempre possui coleções com muitas sementes ou muitas vezes as sementes de algumas espécies são bastante pequenas. Uma forma de diminuir os custos do uso dessa técnica, seria usar primers de regiões conservadas que serviriam para mais de uma espécie, como também utilizar essa técnica mais para as coleções com poucas amostras e espécies com sementes pequenas.

A avaliação do IM e da frequência de ACs foram auxiliares na avaliação da integridade das sementes, tanto de soja quanto de cevada, pois permitiram a distinção entre os lotes de sementes em diferentes estágios de deterioração, além de ser uma metodologia barata.

Todas as metodologias avaliadas devem ser aprimoradas, como também devem ser avaliadas outras metodologias para avaliação da integridade e sistema de reparo do DNA, como por exemplo, o ensaio cometa e a citometria de fluxo. 